
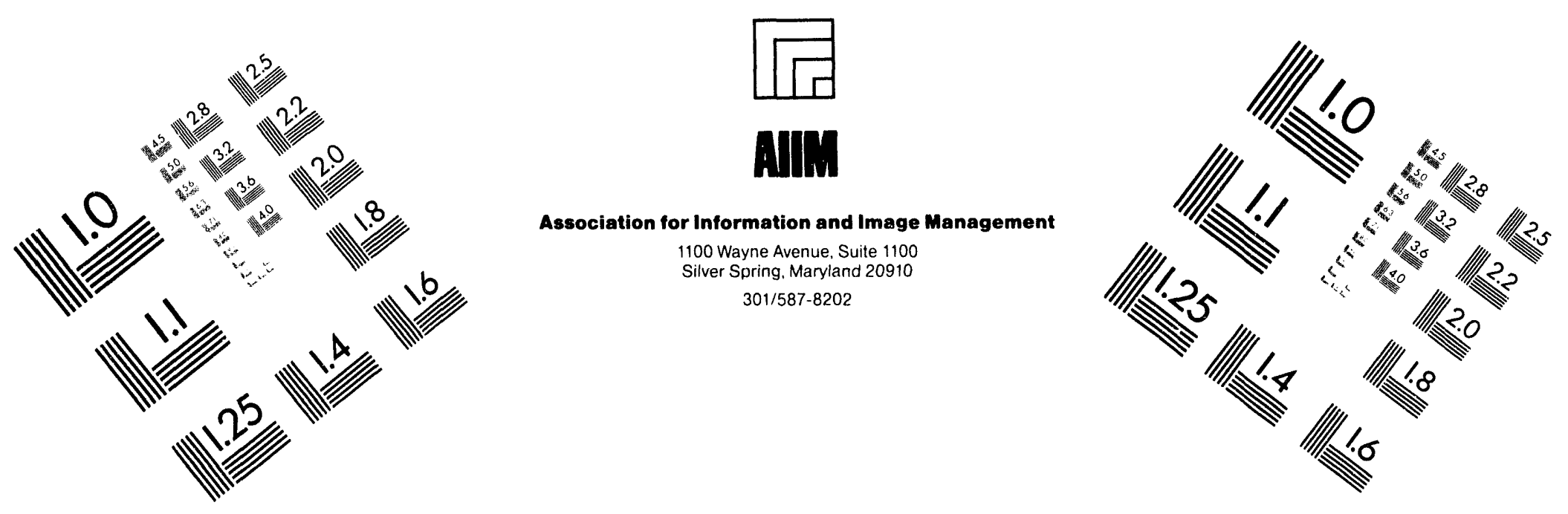

Centimeter

|m Inches
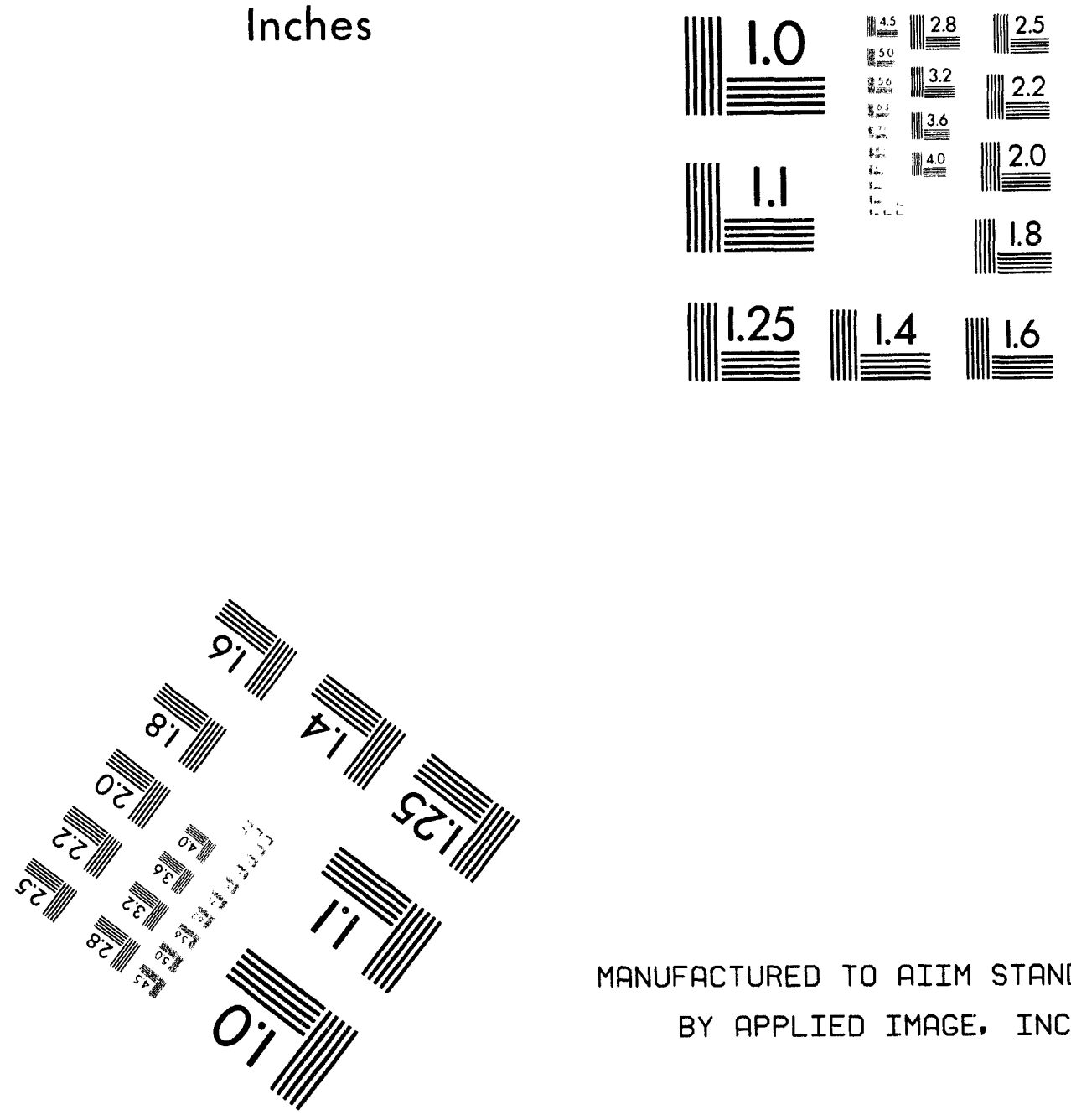

MANUFACTURED TO AIIM STANDARDS

BY APPLIED IMAGE, INC.

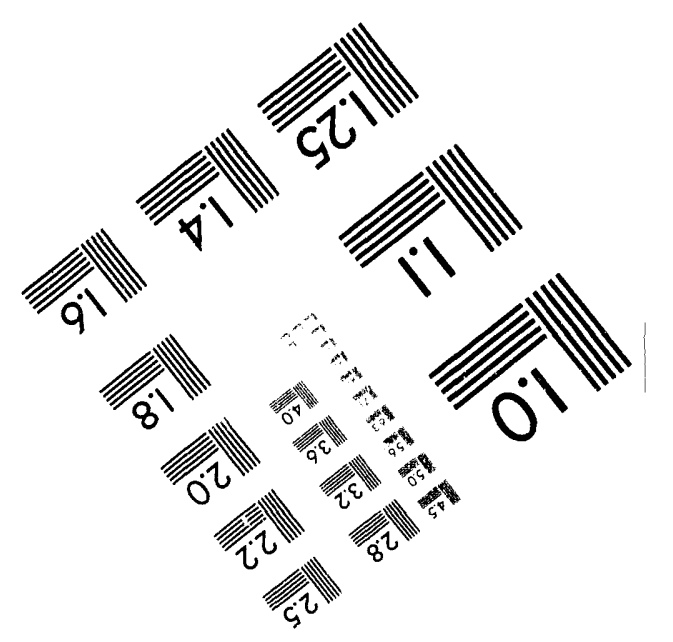



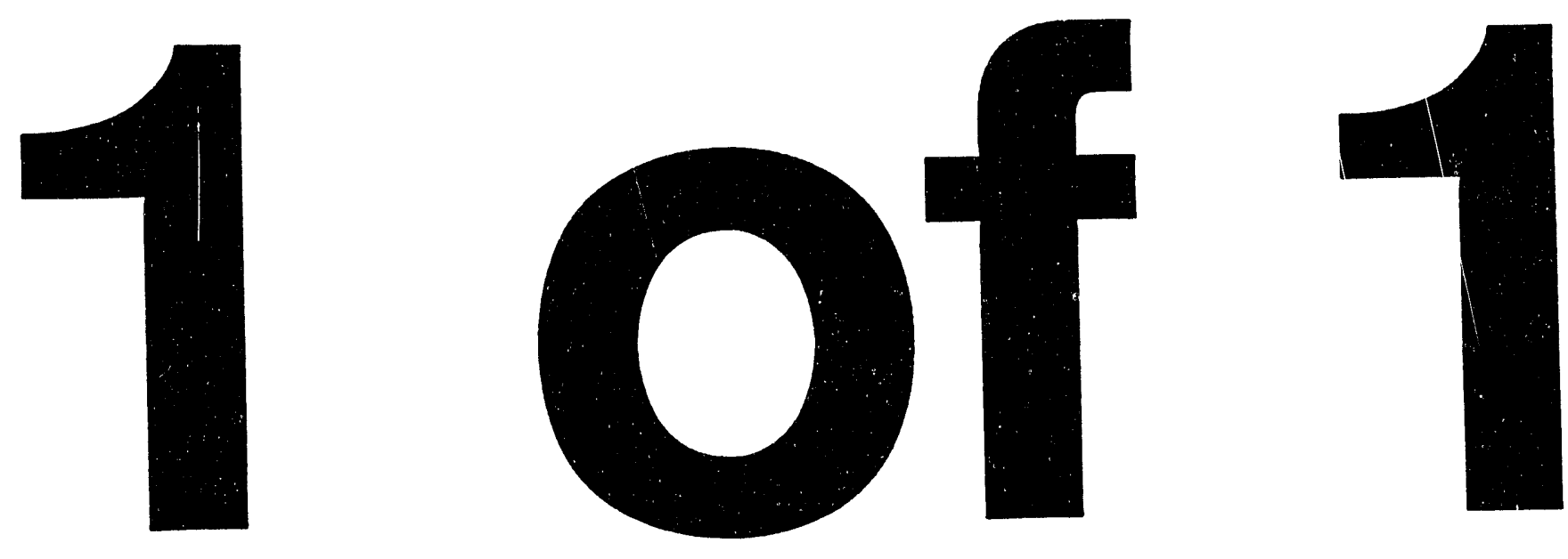
NUREG/CR-6151

PNL-8912

\section{Feasibility of Developing \\ Risk-Based Rankings of Pressure Boundary Systems for Inservice Inspection}

Manuscript Completed: November 1993

Date Published: August 1994

Prepared by

T. V. Vo, B. W. Smith, F. A. Simonen, B. F. Gore

Pacific Northwest Laboratory

Richland, WA 99352

Prepared for

Division of Engineering

Office of Nuclear Regulatory Research

U.S. Nuclear Regulatory Commission

Washington, DC 20555-0001

NRC FIN B2289 


\begin{abstract}
The goals of the .Evaluation and Improvement of Nondestructive Examination Reliability for the In-service Inspection of Light Water Reactors Program sponsored by the Nuclear Regulatory Commission at Pacific Northwest Laboratory (PNL) are to 1) assess current ISI techniques and requirements for all pressure boundary systems and components, 2) determine if improvements to the requirements are needed, and 3) if necessary, develop recommendations for revising the applicable ASME Codes and regulatory requirements. In evaluating approaches that could be used to provide a technical basis for improved inservice inspection plans, PNL has developed and applied a method that uses results of probabilistic risk assessment (PRA) to
\end{abstract}

Abstract

establish piping system ISI requirements. In the PNL program, the feasibility of generic ISI requirements is being addressed in two phases. Phase $I$ involves identifying and prioritizing the systems most relevant to plant safety. The results of these evaluations will be later consolidated into requirements for comprehensive inservice inspection of nuclear power plant components that will be developed in Phase II. This report presents Phase I evaluations for eight selected plants and attempts to compare these PRA-based inspection priorities with current ASME Section XI requirements for Class 1, 2 and 3 systems. These results show that there are generic insights that can be extrapolated from the selected plants to specific classes of light water reactors. 


\section{Contents}

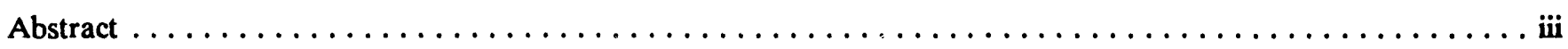

Executive Summary $\ldots \ldots \ldots \ldots \ldots \ldots \ldots \ldots \ldots \ldots \ldots \ldots \ldots \ldots \ldots \ldots \ldots \ldots \ldots \ldots \ldots \ldots \ldots \ldots$

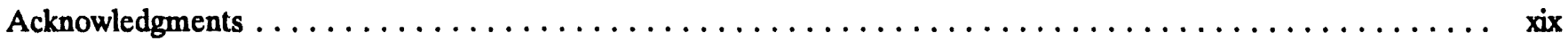

Previous Reports in Series $\ldots \ldots \ldots \ldots \ldots \ldots \ldots \ldots \ldots \ldots \ldots \ldots \ldots \ldots \ldots \ldots \ldots \ldots \ldots \ldots \ldots \ldots \ldots$

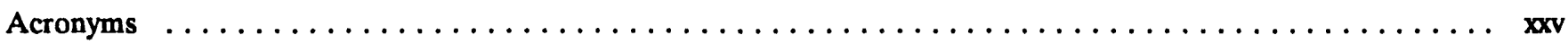

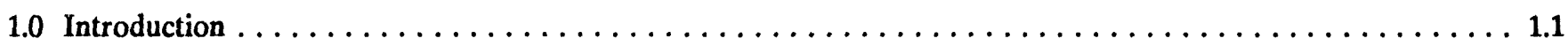

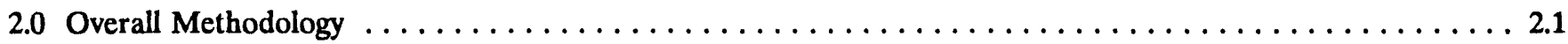

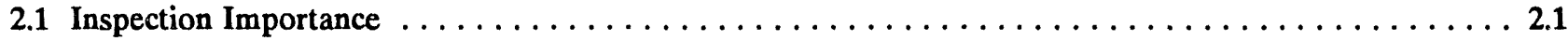

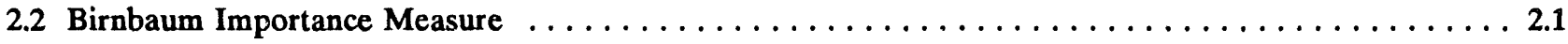

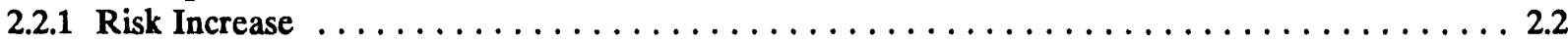

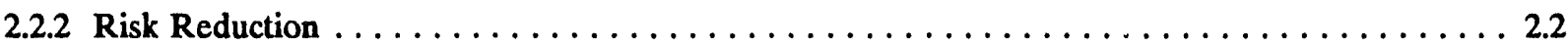

2.3 Piping System Failure Probability $\ldots \ldots \ldots \ldots \ldots \ldots \ldots \ldots \ldots \ldots \ldots \ldots \ldots \ldots \ldots \ldots \ldots \ldots \ldots \ldots \ldots \ldots \ldots \ldots$

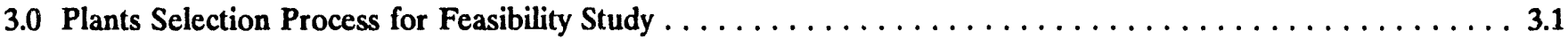

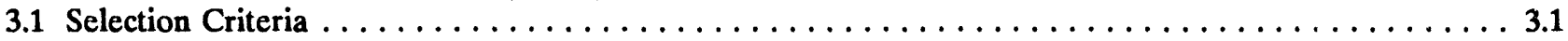

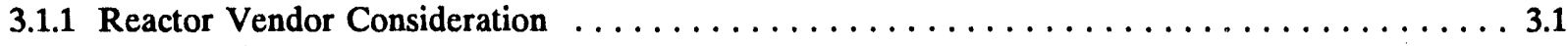

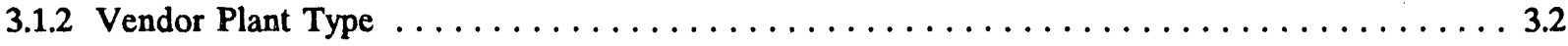

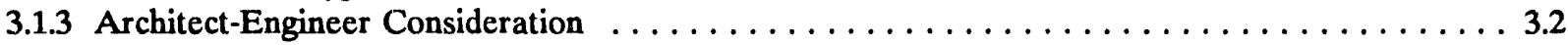

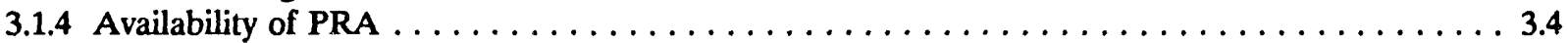

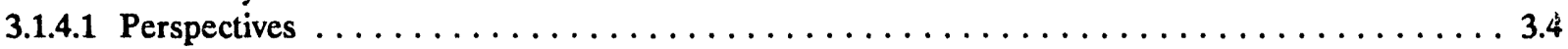

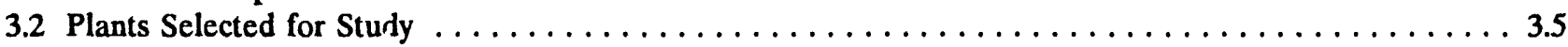

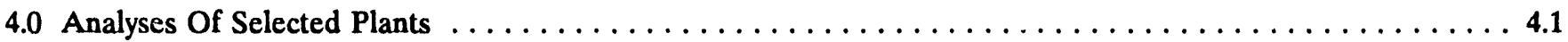

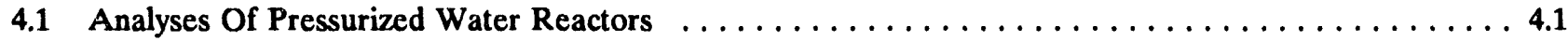

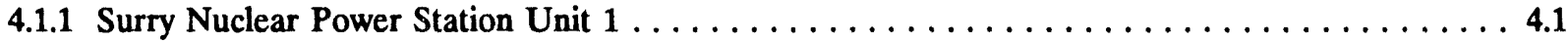

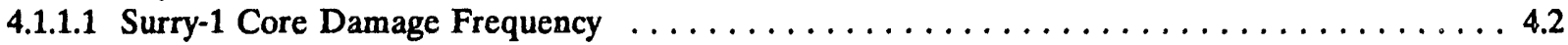

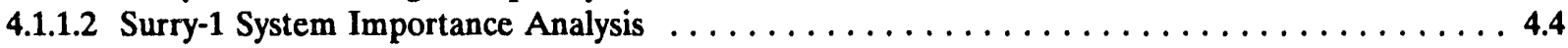

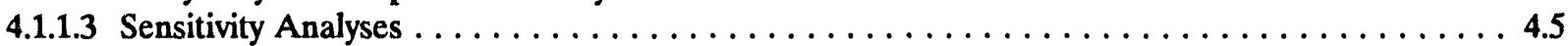

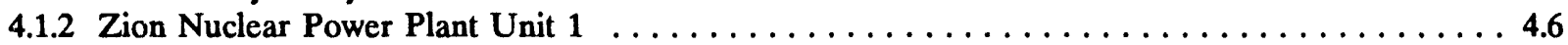

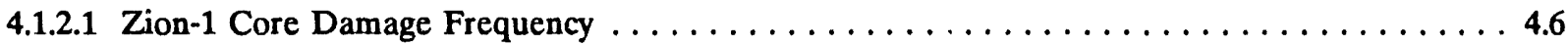

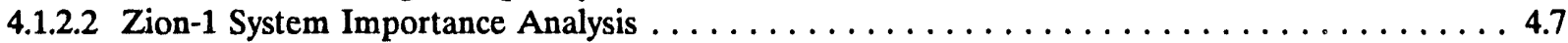

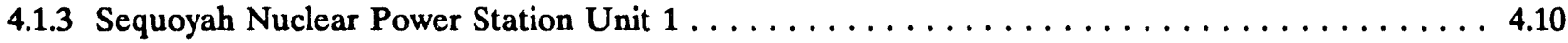

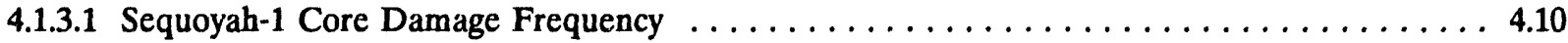

4.1.3.2 Sequoyah-1 System Importance Analysis $\ldots \ldots \ldots \ldots \ldots \ldots \ldots \ldots \ldots \ldots \ldots \ldots \ldots .11$

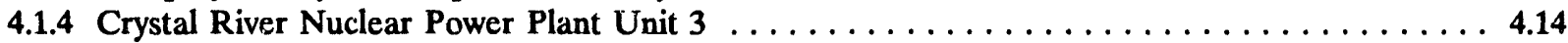

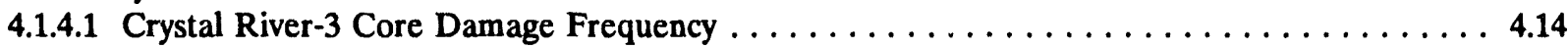

4.1.4.2 Crystal River-3 System Importance Analysis $\ldots \ldots \ldots \ldots \ldots \ldots \ldots \ldots \ldots \ldots \ldots \ldots . \ldots \ldots$

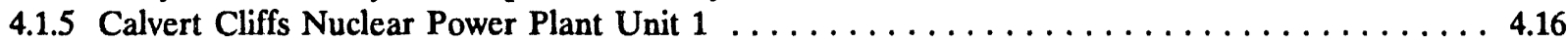

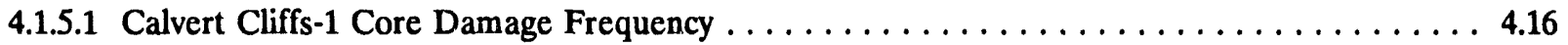

4.1.5.2 Calvert Cliffs-1 System Importance Analysis $\ldots \ldots \ldots \ldots \ldots \ldots \ldots \ldots \ldots \ldots \ldots \ldots .18$

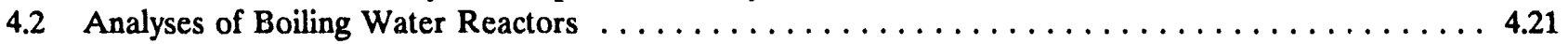

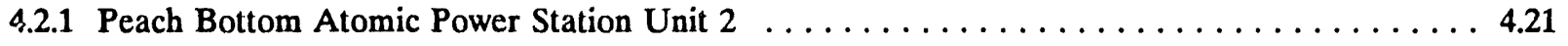




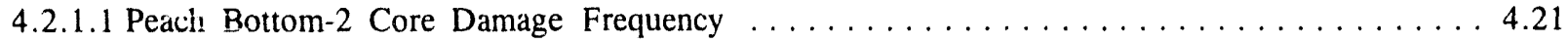

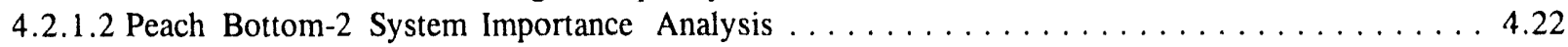

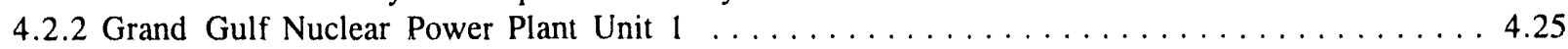

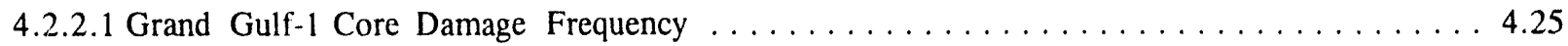

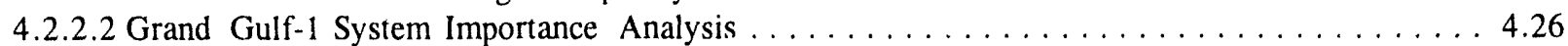

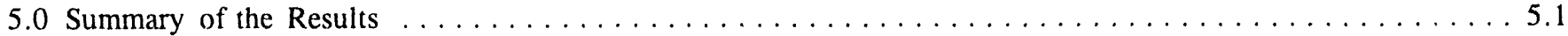

5.1 Summary of Inspection Importance Results for PWR Systems $\ldots \ldots \ldots \ldots \ldots \ldots \ldots \ldots \ldots \ldots \ldots .1$

5.2 Summary of Inspection Importance Results for BWR Systems $\ldots \ldots \ldots \ldots \ldots \ldots \ldots \ldots \ldots \ldots .3$

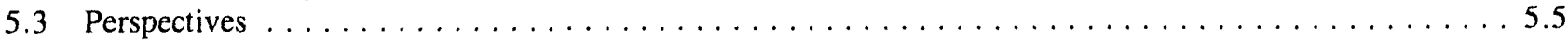

6.0 Summary and Conclusions $\ldots \ldots \ldots \ldots \ldots \ldots \ldots \ldots \ldots \ldots \ldots \ldots \ldots \ldots \ldots \ldots \ldots \ldots \ldots \ldots \ldots \ldots \ldots \ldots \ldots \ldots .1$

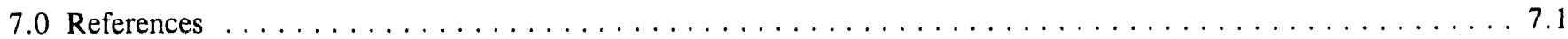

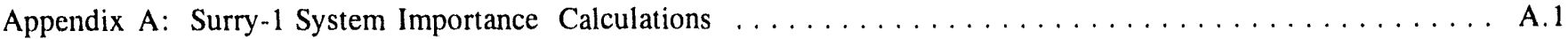

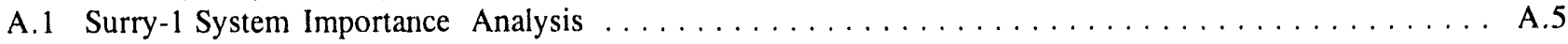

A.2 Inspection Importance Calculations $\ldots \ldots \ldots \ldots \ldots \ldots \ldots \ldots \ldots \ldots \ldots \ldots \ldots \ldots \ldots \ldots \ldots \ldots$

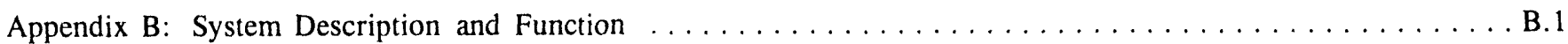

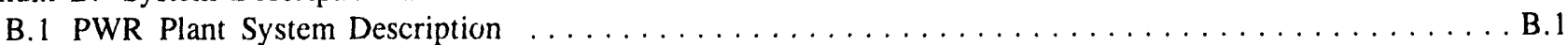

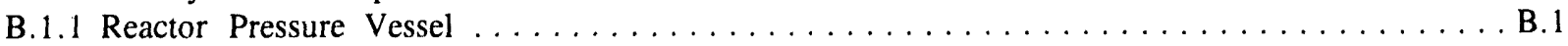

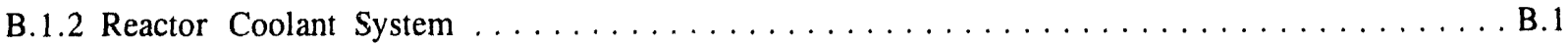

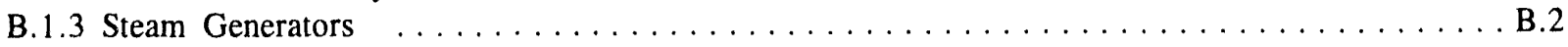

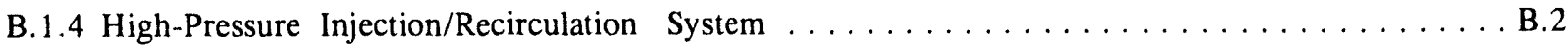

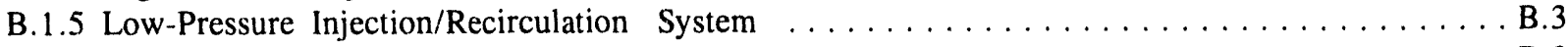

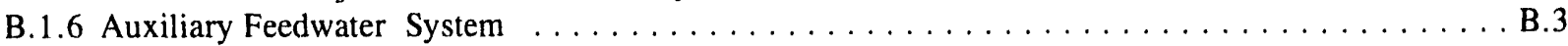

B.1.7 Cooling Water-Component Cooling Water, Service Water System $\ldots \ldots \ldots \ldots \ldots \ldots \ldots$ B.3

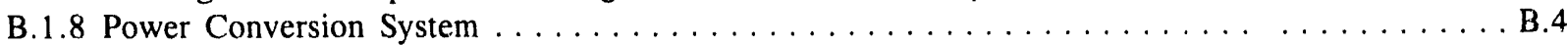

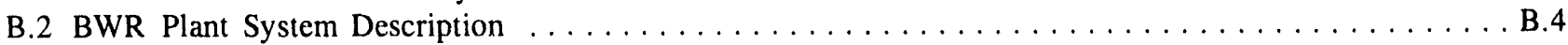

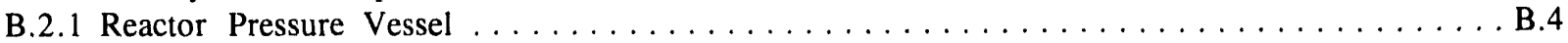

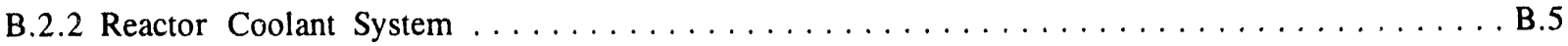

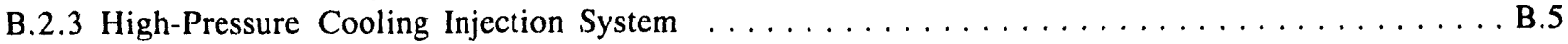

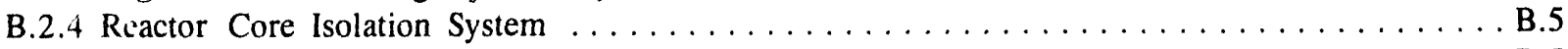

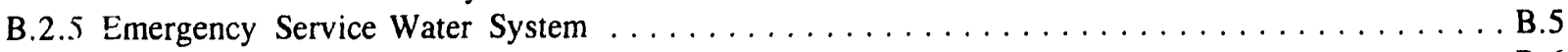

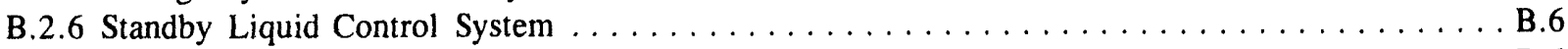

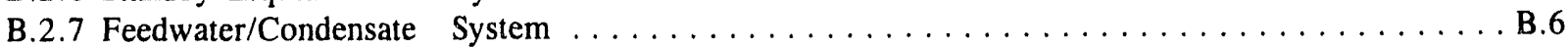

B.2.8 Power Conversion/Main Steam System $\ldots \ldots \ldots \ldots \ldots \ldots \ldots \ldots \ldots \ldots \ldots \ldots \ldots \ldots \ldots \ldots \ldots \ldots \ldots$ 


\section{Figures}

ES.1. Inspection Importance Ranking for Various PWR Systems Based on Core Damage Frequency ...... xii

ES.2. Birnbaum Importance Ranking for Various PWR Systems Based on Core Damage . . . . . . . . xiii

ES.3. Inspection Importance Ranking for Various BWR Systems Based on Core Damage . . . . . . . . . xiv

ES.4. Birnbaum Importance Ranking for Various BWR Systems Based on Core Damage Frequency ...... xvi

5.1. Inspection Importance Ranking for Various PWR Systems Based on Core Damage Frequency . . . . 5.2

5.2. Birnbaum Importance Ranking for Various PWR Systems Based on Core Damage Frequency . . . . 5.3

5.3. Inspection Importance Ranking for Various BWR Systems Based on Core Damage Frequency . . . . 5.4

5.4. Birnbaum Importance Ranking for Various BWR Systems Based on Core Damage Frequency . . . . 5.6 


\section{Tables}

ES.1. Plants Selected for Feasibility Study $\ldots \ldots \ldots \ldots \ldots \ldots \ldots \ldots \ldots \ldots \ldots \ldots \ldots \ldots \ldots \ldots \ldots$

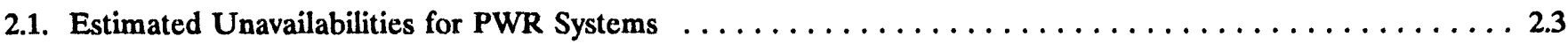

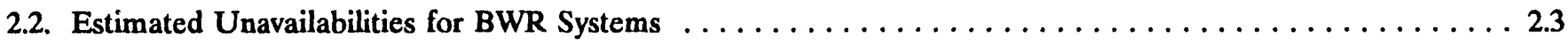

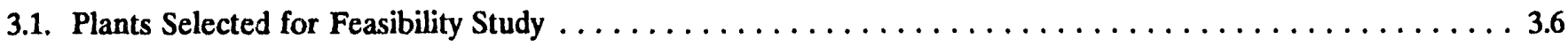

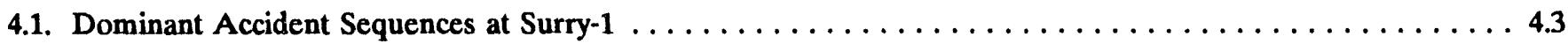

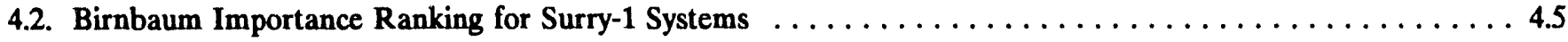

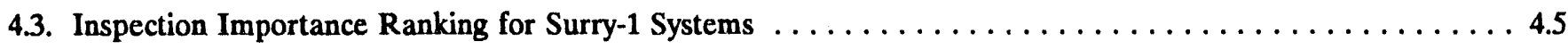

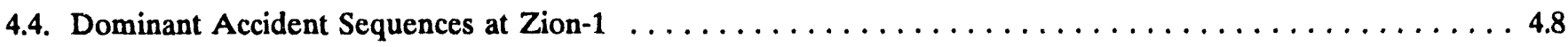

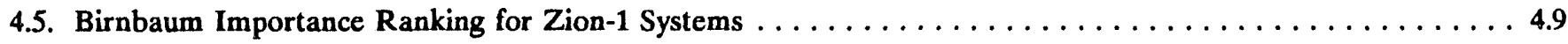

4.6. Inspection Importance Ranking for Zion-1 Systems $\ldots \ldots \ldots \ldots \ldots \ldots \ldots \ldots \ldots \ldots \ldots \ldots \ldots$

4.7. Dominant Accident Sequences at Sequoyah-1 $\ldots \ldots \ldots \ldots \ldots \ldots \ldots \ldots \ldots \ldots \ldots \ldots \ldots \ldots \ldots \ldots \ldots \ldots$

4.8. Birnbaum Importance Ranking for Sequoyah-1 $\ldots \ldots \ldots \ldots \ldots \ldots \ldots \ldots \ldots \ldots \ldots \ldots \ldots \ldots \ldots$

4.9. Inspection Importance Ranking for Sequoyah-1 $\ldots \ldots \ldots \ldots \ldots \ldots \ldots \ldots \ldots \ldots \ldots \ldots \ldots \ldots \ldots \ldots \ldots$

4.10. Dominant Accident Sequences at Crystal River-3 $\ldots \ldots \ldots \ldots \ldots \ldots \ldots \ldots \ldots \ldots \ldots \ldots \ldots \ldots \ldots \ldots \ldots \ldots$

4.11. Birnbaum Importance Ranking for Crystal River-3 $\ldots \ldots \ldots \ldots \ldots \ldots \ldots \ldots \ldots \ldots \ldots \ldots \ldots$

4.12. Inspection Importance Ranking for Crystal River-3 $\ldots \ldots \ldots \ldots \ldots \ldots \ldots \ldots \ldots \ldots \ldots \ldots \ldots .17$

4.13. Dominant Accident Sequences at Calvert Cliffs-1 $\ldots \ldots \ldots \ldots \ldots \ldots \ldots \ldots \ldots \ldots \ldots \ldots \ldots \ldots$

4.14. Birnbaum Importance Ranking for Calvert Cliffs $-1 \ldots \ldots \ldots \ldots \ldots \ldots \ldots \ldots \ldots \ldots \ldots \ldots \ldots .21$

4.15. Inspection Importance Ranking for Calvert Cliffs-1 $\ldots \ldots \ldots \ldots \ldots \ldots \ldots \ldots \ldots \ldots \ldots \ldots \ldots .21$

4.16. Dominant Accident Sequences at Peach Bottom-2 $\ldots \ldots \ldots \ldots \ldots \ldots \ldots \ldots \ldots \ldots \ldots \ldots \ldots \ldots \ldots \ldots \ldots \ldots \ldots .23$

4.17. Birnbaum Importance Ranking for Peach Bottom-2 $\ldots \ldots \ldots \ldots \ldots \ldots \ldots \ldots \ldots \ldots \ldots \ldots \ldots .24$

4.18. Inspection Importance Ranking for Peach Bottom-2 $\ldots \ldots \ldots \ldots \ldots \ldots \ldots \ldots \ldots \ldots \ldots \ldots \ldots$

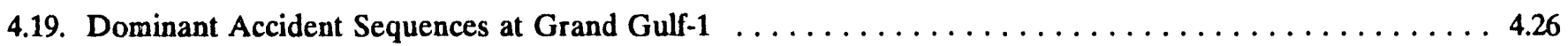

4.20. Birnbaum Importance Ranking for Grand Gulf-1 $\ldots \ldots \ldots \ldots \ldots \ldots \ldots \ldots \ldots \ldots \ldots \ldots \ldots \ldots .27$

4.21. Inspection Importance Ranking for Grand Gulf-1 $\ldots \ldots \ldots \ldots \ldots \ldots \ldots \ldots \ldots \ldots \ldots \ldots \ldots \ldots \ldots \ldots \ldots \ldots \ldots$ 
Tables

5.1. Current ASME Classification and Inservice Inspection Requirements for Various PWR Systems $\ldots \ldots \ldots 5.7$

5.2. Current ASME Classification and Inservice Inspection Requirements for Various BWR Systems $\ldots \ldots \ldots 5.7$

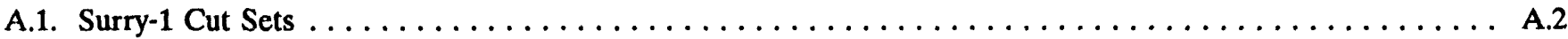

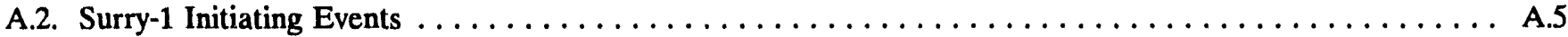

A.3. Summary of Importance Measures for Surry-1 Systems $\ldots \ldots \ldots \ldots \ldots \ldots \ldots \ldots \ldots \ldots$

A.4. Birnbaum Importance Ranking for Surry-1 Systems $\ldots \ldots \ldots \ldots \ldots \ldots \ldots \ldots \ldots \ldots \ldots \ldots \ldots \ldots \ldots$

A.5. Estimated Pipe Failure Probabilities for PWR Piping Systems $\ldots \ldots \ldots \ldots \ldots \ldots \ldots \ldots \ldots \ldots \ldots$ A.7

A.6. Inspection Importance Ranking for Surry-1 Systems $\ldots \ldots \ldots \ldots \ldots \ldots \ldots \ldots \ldots \ldots \ldots \ldots \ldots \ldots \ldots$ 


\section{Executive Summary}

The Evaluation and Improvement of Nondestructive Examination (NDE) Reliability for Inservice Inspection (ISI) of Light Water Reactors (LWR) program is being conducted at the Pacific Northwest Laboratory (PNL) for the U.S. Nuclear Regulatory Commission (NRC). The objectives are to determine the reliability of current inservice inspections (ISI) of pressure boundary systems and components and to develop recommendations that can ensure high inspection reliability. The long-term objective is to recommend improvements to overcome shortcomings in Section XI of the American Society of Mechanical Engineer's Code for inspection of nuclear power plant components. In the PNL program, the feasibility of generic ISI requirements is being evaluated in two phases. Phase I involves identifying and prioritizing the systems most relevant to plant safety. This report presents the Phase I system results for eight plants and attempts to compare these PRA-based inspection priorities with current ASME Section XI requirements for Class 1, 2, and 3 systems. Phase II will consolidate these results into requirements for comprehensive inservice inspection of nuclear power plant components.

After evaluating several approaches, PNL developed and applied a method using probabilistic risk assessment (PRA) results to establish system ISI requirements (Vo et al. 1989a). The method uses the Inspection Importance Measure ${ }^{(a)}\left(I^{\text {b }}\right)$ to rank safety-related systems. Physically, $\mathrm{I}^{\mathrm{w}}$ is an approximation of core-melt risk due to failures of systems and/or components caused by pipe failures. For this application, $\mathrm{I}^{\mathrm{W}}$ for a system is defined as the Birnbaum Importance Measure multiplied by the piping-failure probability for that system.

The Birnbaum Importance Measure, $\mathrm{I}^{\mathrm{B}}$, for a system can be interpreted as a conditional probability of core damage given that the system fails. $I^{B}$ is determined by using the PRA results. The piping-failure probabilities can be determined from either fracture mechanics analyses or from historical data. This study used the estimates based on observed piping-failure data from operating nuclear power plants in the United States.

The ranking process is a two step approach where the Birnbaum Importance Measure ranks the systems according to their importance to safety. The inclusion of the Inspection Importance Measure is to elevate other systems into a higher category of inspection requirements but never to lower any systems. This way systems important to safety given failure are identified and then those that may be less important from a safety standpoint but have a higher failure probability will end up being inspected in an equivalent manner.

The process of selecting the plants for study began with a review of the commercial LWRs in the United States. The objective was to select a cross section of plants representative of all operating LWRs. The selection process considered the reactor vendor, the plant type, the architect engineer, containment design, and the availability of a PRA. The plants selected are listed in Table ES.1.

Table ES.1. Plants Selected for Feasibility Study

Plant Name

Surry-1

Zion-1

Sequoyah-1

Oconee-3

Crystal River-3

Calvert Cliffs-1

Peach Bottom-2

Grand Gulf-1
Vendor/Type/A-E/Containment

W/HP/Stone \& Webster/Subatmospheric

W/HP/Sargent \& Lundy/Large, Dry

W/HP/Utility/Ice Condenser

B\&W/-/Bechtel-Utility/Large, Dry

B\&W/-/Gilbert/Large, Dry

CE/-/Bechtel/Large, Dry

GE/BWR4/Bechtel/Mark I

GE/BWR6/Bechtel/Mark III

(a) The parameter $I^{w}$ is referred to as the Weld Inspection Importance Measure in Vo, et al. (1989a). 
Figure ES.1 shows the ranking based on $I^{\mathrm{w}}$ for various systems of the six PWRs studied. Systems having the lowest rank (e.g., one) represent the most important systems to inspect. The low-pressure injection system, the high-pressure injection system, and the reactor pressure vessel system are ranked as most important with respect to pipe failure. The importance of the low pressure injection and the high-pressure injection systems are primarily due to their functions in providing emergency coolant injection and recirculation following a transient or accident. The reactor pre'sure vessel is important because it prevents the reactor core from being uncovered following an accident.

The service water system, auxiliary feedwater system, and the steam generator system follow in importance. The importance of the service water system is primarily due to its important function in providing cooling water to multiple front-line systems or other key support equipment during an accident. The auxiliary feedwater system and the steam generator system are important primarily due to their functions in providing feedwater to the steam generators and/or to provide heat removal from the primary system following an undesired event. The reactor coolant system and the power conversion system are ranked as the least risk-important systems.

Figure ES.2 shows the system rankings for the six PWRs based on $I^{B}$. Based on this importance measure, the most important systems are the reactor pressure vesstl, the low-pressure injection system, the service water system, the high-pressure injection system, the reactor coolant system, and the auxiliary feedwater system. The least important systems based on the Birnbaum Importance Measure are the steam generator and the power conversion system. Factors that cause the rankings, either based on $I^{w}$ or $I^{B}$, for individual systems at particular plants to differ from the norms were:

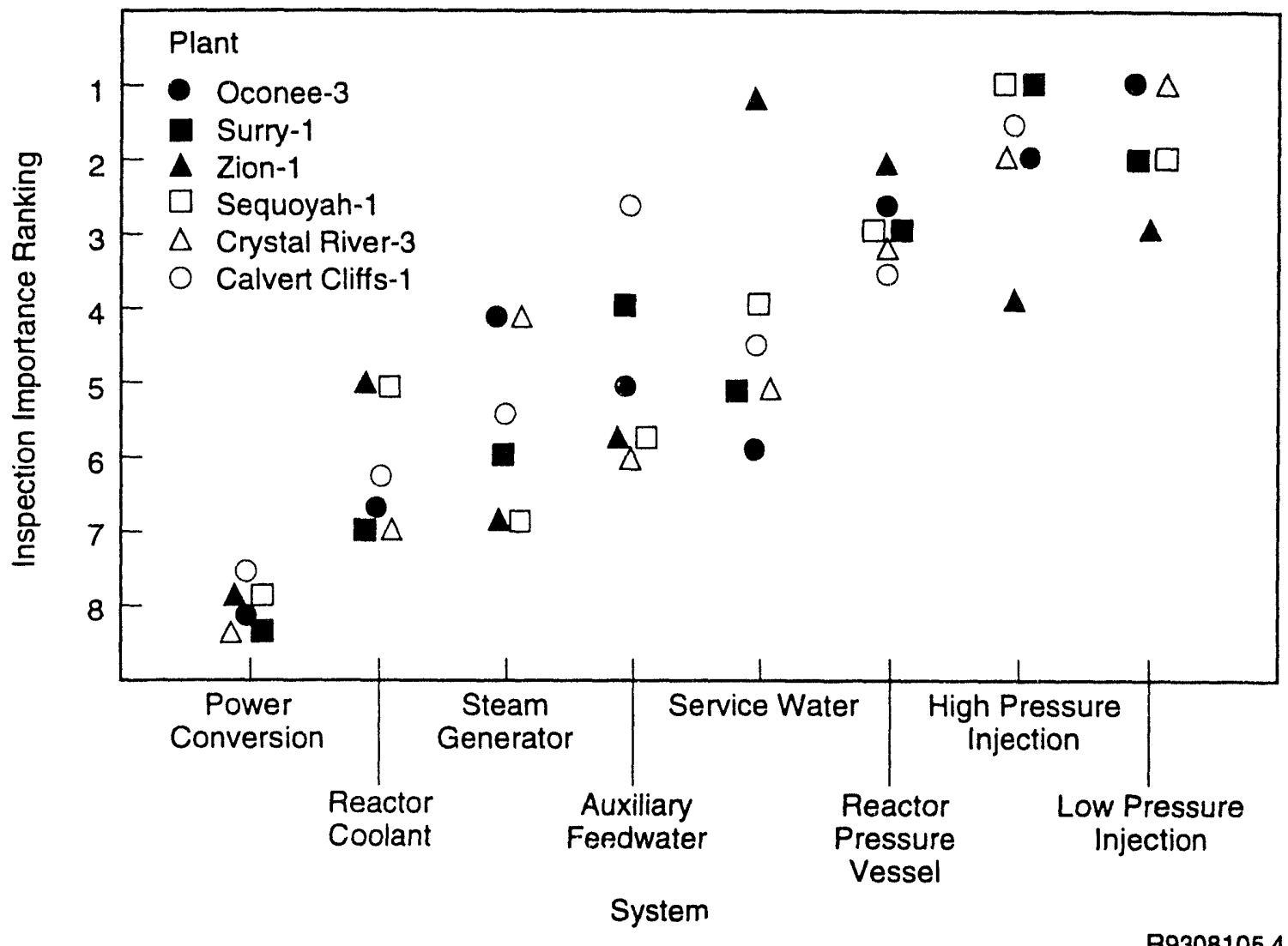

R9308105.4

Figure ES.1. Inspection Importance Ranking for Various PWR Systems Based on Core Damage Frequency 


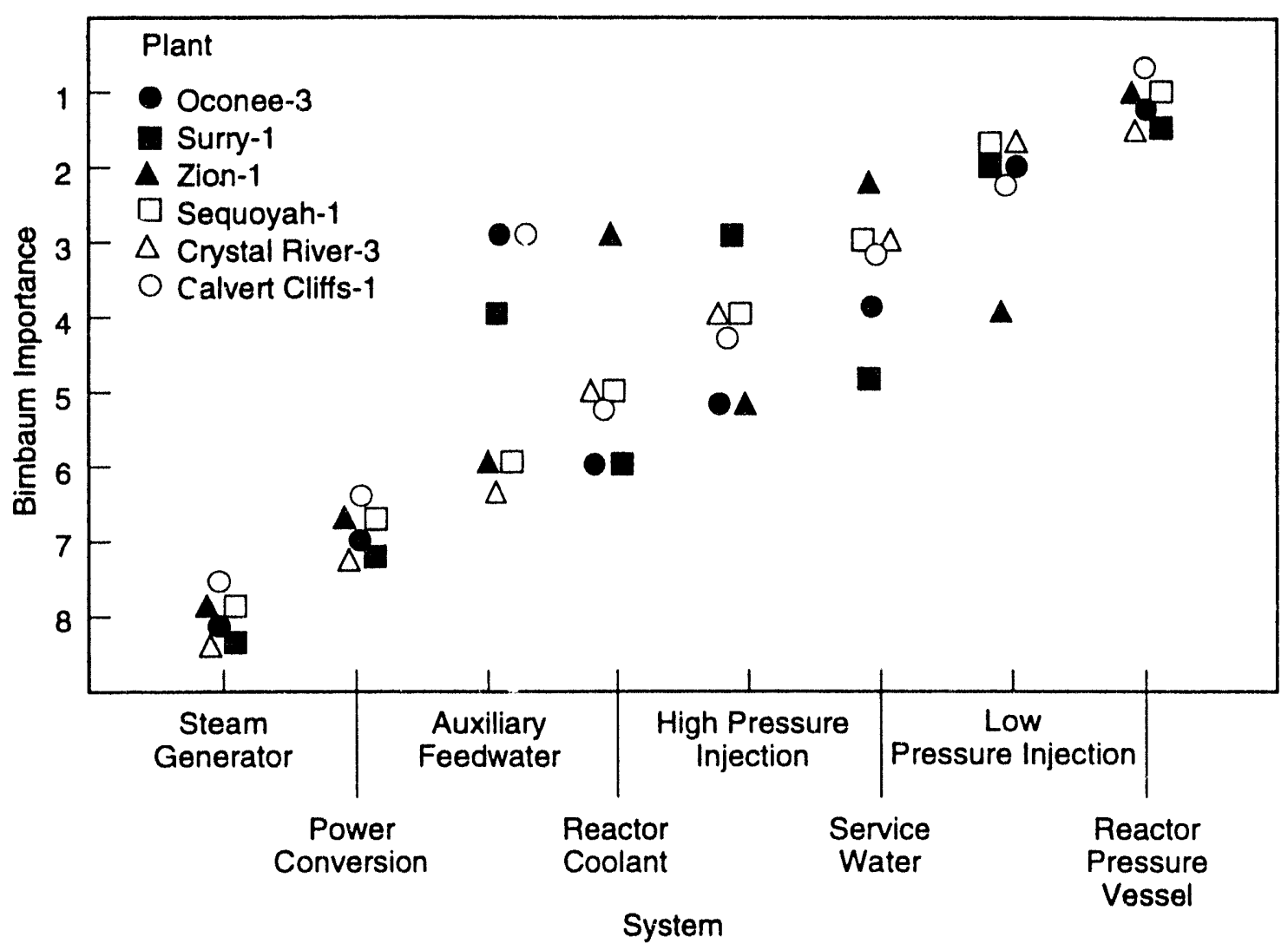

Figure ES.2. Birnbaum Importance Ranking for Various PWR Systems Based on Core Damage

- The low-pressure injection system at Calvert Cliffs is not shown as risk-important because a large loss of coolant accident (LOCA) was not risk significant. Because of design and operating procedure differences, the high-pressure injection system is a preferred system (for all LOCA sizes) in the recirculation mode operation. The low-pressure injection system operates in the recirculation mode for recovery.

- The auxiliary feedwater systems at Calvert Cliffs and Surry rank higher in importance than at the other PWRs, primarily due to the relatively frequent demand for this system as compared with the other plants.

- The service water systems at Zion and Sequoyah rank above the norms because this system is needed for operation of the charging and high-pressure safety injection pumps at these plants. Loss of this system may cause a small LOCA and disable the systems needed to mitigate a small LOCA.

- The reactor coolant systems at Sequoyah and Zion are higher in ranking compared with the other PWRS. This is due to a seal LOCA event and high unavailabilities of systems needed to mitigate seal LOCA.

- For Sequoyah the reactor coolant systum has greater importance to the core damage frequency from the LOCA scenarios (excluding seal LOCA) bccause of its ice condenser containment. In that design, the containment sprays actuate at a lower pressure setpoint than with a large dry containment design, resulting in containment spray actuation over a larger break-size spectrum. This causes faster depletion of the refueling water storage tank 


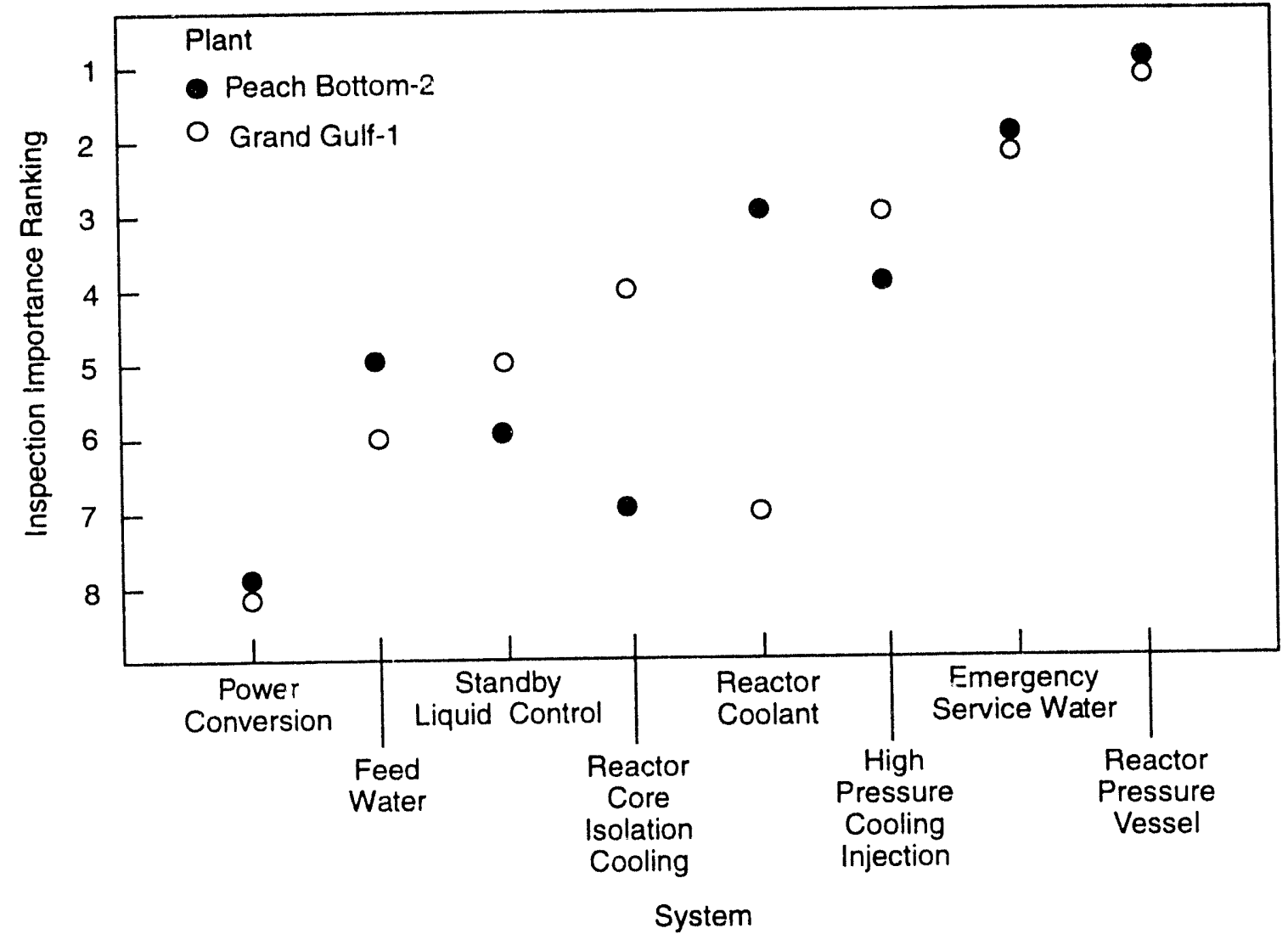

R9308105.1

Figure ES.3. Inspection Importance Ranking for Various BWR Systems Based on Core Damage

and an earlier switch to the recirculation mode. This switchover is a complex manual operation that must be done quickly under stress.

- The steam generator system has relatively the same importance ranking for all plants analyzed. At Oconee- 3 and Crystal River-3 the higher importance ranking is due to a larger estimated frequency of steam generator tube rupture (SGTR), and/or higher failure probabilities associated with the sequences with SGTR.

Figure ES. 3 shows the rankings based on $I^{\mathrm{w}}$ for the two BWRs studied. Most safety systems for the two BWRs have relatively the same rank. The reactor pressure vessel, the emergency service water system, and the high-pressure cooling injection system are the most important systems with respect to pipe failure.

Although the reactor pressure vessel is the most impor- tant system, it is not viewed as a major safety concern for these plants. The reactor pressure vessel is ranked highest only because the other systems have even lower importance as potential contributors to core damage frequency.

The relatively high importance of the emergency service water system is due to its vital function in providing cooling water to front-line systems or key support equipment during an accident. Emergency service water appears in most accident sequences of the two BWR PRAs, where it either fails as a system or indirectly causes failure through loss of diesel generator cooling.

The importance of the high-pressure cooling injection system is due to its function in providing coolant to the reactor vessel during accidents in which pressure remains high (e.g., a station blackout event). The im- 
portance measure for the high pressure cooling injection system at Grand Gulf-1 is slightly higher than at Peach Bottom-2. The reason is that the high-pressure cooling injection at Grand Gulf-1 is more susceptible to failure due to its high suppression pool temperature.

The reactor coolant system, the reactor core isolation cooling system, the standby liquid control system, the feedwater system, and the power conversion system follow in importance. For the reactor coolant system and the reactor core isolation system, there are notable differences in the rankings between Grand Gulf-1 and Peach Bottom-2. The reactor coolant system at Grand Gulf-1, a BWR $/ 6$, uses a motor-driven high-pressure core spray system for high pressure addition of coolant to the reactor vessel rather than a steam-driven highpressure core spray system as used at Peach Bottom-2. This motor driven approach improves the system reliability. Grand Guif-1 also has a third train of lowpressure coolant injection that injects directly into the reactor core, and thus has one more train than Peach Bottom-2 for mitigating large LOCAs.

In contrast, the ranking of the reactor core isolation cooling system at Grand Gulf-1 is higher than at Peach Bottom-2. This is primarily due to differences in containment design and operating procedures. At Grand Gulf- 1 , the reactor core isolation cooling system is rendered inoperable by the high containment pressure (i.e., reactor core isolation cooling system fails because of isolation of high turbine exhaust pressure, caused by the increased containment pressure). At Peach

Bottom-2, the ability to vent steam from the suppression pool or containment during the course of accident scenario prevents the reactor building from being overpressured. This shows the importance of containment venting for long-term decay heat removal at a Mark I BWR.

Figure ES.4 shows the rankings for various BWR systems based on $I^{B}$. In general, all safety systems have similar rankings for the two plants, with snrne variation in the rankings of the reactor coolant syst $\mathrm{sm}$ and the reactor core isolation cooling system due to differences in containment design as discussed above. The results indicate that the most important systems are tix: reactor pressure vessel, the emergency service water, the highpressure cooling injection, the reactor coolant, and the reactor core isolation cooling. Each of the other sys- tems addressed are of lesser importance because of their lower conditional probability of core damage given a total system failure.

\section{Conclusions}

Based on the results presented, it appears that there are generic insights that can be extrapolated from the selected plants to specific classes of LWRs. However, because the results are site-specific, caution must be exercised when making statements about generic classes of plants, or extrapolating this discussion to all LWRs. Information and insights from this study will be compared in future work with results of additional plant specific studies to validate the preliminary ronclusions.

For both PWRs and BWRs, the analyses ind at: the importance of the front-line and the key support systems. For instance, at PWR plants where a single component cooling or service water system is required to provide both methods of reactor coolant pump seal cooling (thermal barrier and seal injection flow), loss of that system, is a major contributor to the core damage frequency. At plants with two independent cooling systems to support reactor coolant pump seal cooling and reactor coolant pump seal failure, LOCA only becomes important in station blackout events. The emergency service water system is important for BWRs because its failure could disable multiple front-line systems or key support systems that are required for an emergency shutdown of the plant.

Differences in containment design also impact the rankings for the safety-related systems. For PWRs, the pressure setpoint for containment spray actuation is a key factor. Plants with higher setpoints can accommodate larger-size breaks without actuation of sprays. Operation of sprays is a factor for refueling water storage tank drainage, which forces the switch to the recirculation mode, and increases the importance of the emergency core cooling systems. For BWR Mark I containment, successful containment venting can increase the operability of the emergency core cooling system.

Comparisons of results for $\mathrm{I}^{\mathrm{w}}$ and $\mathrm{I}^{\mathrm{B}}$ (Figures ES.1 and ES.2 or Figures ES.3 and ES.4) indicate that the system 


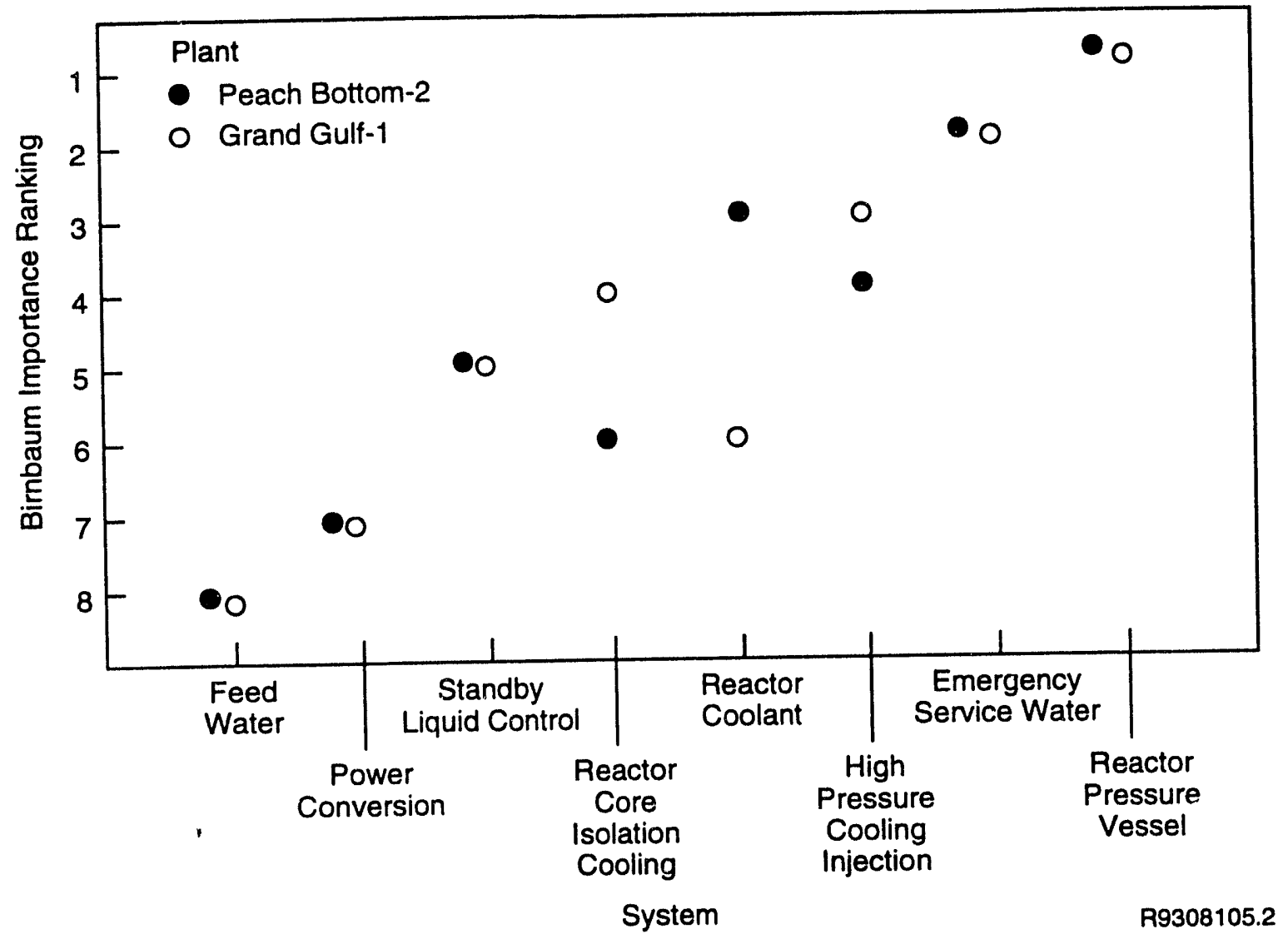

Figure ES.4. Birnbaum Importance Ranking for Various BWR Systems Based on Core Damage Frequency

failure probabilities used may impact the rankings for the safety systems. This study used probabilities based on historical piping-failure data. Rigorous piping-failure analysis (e.g., fracture mechanics calculations using actual plant-specific information) may shift the system importance results.

The numerical results for the Inspection Importance Measures are higher for PWRs than for BWRs. The reason for this is that the core damage frequencies for the PWRs are higher than those of BWRs. The LOCA sequences are less important for the two BWRs studied. This results because the BWRs have multiple and diverse high- and low-pressure einergency core cooling systems, each of which has multiple trains, and a readily available method of rapid depressurization. Moreover,
LOCA events in a BWR can also be mitigated by the main feedwater system, which is both high pressure and high capacity. In contrast, PWRs generally have only one high-pressure and one low-pressure ECC system (both multitrain), plus a set of accumulators. The PWR emergency core cooling system has considerable redundancy, but not as much as a BWR.

The results were compared with the typical ASME classifications and inservice inspection requirements for the PWR and BWR systems. This indicates that, at least for the systems evaluated, the ASME classifications and inservice inspection requirements are in general agreement with the calculated importance ranking with the exception of the service water systems at PWRs and the emergency service water systems at 
BWRs. All systems that are ranked as most important to safety are currently required to be volumetrically examined by Section XI of the ASME Boiler and Pressure Vessel Code. The notable exceptions are the service water systems which generally require only a visual examination. The service water systems would be candidates for more extensive examinations. However, a more detailed component analysis of these systems would be required before recommendations for specific requirements can be developed.

Although beyond the scope of this study, human interactions have been found to be important contributors to safety of nuclear power p!ants. The ability of the operator to actuate alternative systems and to recover failed functions can lead to a significant reduction in coredamage frequency. The key is having sufficient time and adequate written procedures to support the recovery action. There is significant variability in the quality of the procedures and training from plant to plant as indicated in the PRA models.

Sensitivity analyses were only performed on those issues whose potential impact on system ranking was significant. For the plants studied, the sensitivity analyses addressed the effects of significant increases of pipe failure probability. This was accomplished by letting the piping system failure probabilities approach 1.0. This causes $I^{\mathrm{w}}$ values to be the same as $I^{B}$ values, and the new $\mathrm{I}^{\mathrm{W}}$ ranking to be the same as the $\mathrm{I}^{\mathrm{B}}$.
In general, it has been concluded that 1) the method has been demonstrated to be useful for identifying generic systems in nuclear power plants to be inspected, and 2) the insights gained are useful in focusing attention on important matters and design details and, therefore, can serve as a foundation for future studies. The extent to which generic insights can be drawn from the eight plant analyses, and the degree to which this information and plant-specific results can then be applied to other operating plants often resides in the nature of the specific issue being addressed.

Generic conclusions will remain unclear until a systematic evaluation of the sensitivity of the results to plani specific design factors and operating procedures can be made. What can be stated is that this study provided a resource to address some of the present-day regulatory considerations of the U.S. Nuclear Regulatory Commission (NRC). Specifically, detailed information is presented that can assist the NRC in developing the methods and data to set priorities for inspection activities.

In future work to validate current results, detailed plant system analyses, improved piping-failure analyses, cost and benefit analyses, and other analytical methods will be used to analyze the major systems in the selected plants. Those results will be used to develop improved plans for comprehensive inservice inspection requirements for pressure boundary systems and components at LWRs. 


\section{Acknowledgments}

This work was supported by the U.S. Nuclear Regulatory Commission under contract DE-AC06-76RLO 1830. The authors wish to acknowledge the direction and support provided by Dr. Joe Muscara, the NRC program manager, and Dr. Steve Doctor, the PNL program manager. The authors also would like to express appreciation to T. T. Taylor for his reviews and comments on this report. 


\section{Previous Reports in Series}

Doctor, S. R., A. A. Diaz, J. R. Friley, M. S. Good, M. S. Greenwood, P. G. Heasler, R. L. Hockey, R. J. Kurtz, F. A. Simonen, J. C. Spanner, T. T. Taylor, and T. V. Vo. 1993. Nondestructive Examination (NDE) Reliability for Inservice Inspection of Light Water Reactors. NUREG/CR-4469, PNL-5711, Vol. 15. Pacific Northwest Laboratory, Richland, Washington.

Doctor, S. R., A. A. Diaz, J. R. Friley, M. S. Good, M. S. Greenwood, P. G. Heasler, R. L. Hockey, R. J. Kurtz, F. A. Simonen, J. C. upanner, T. T. Taylor, and T. V. Vo. 1992. Nondestructive Examination (NDE) Reliability for Inservice Inspection of Light Water Reactors. NUREG/CR-4469, PNL-5711, Vol. 14. Pacific Northwest Laboratory, Richland, Washington.

Green, E. R., S. R. Doctor, R. L. Hockey, and A. A. Diaz. 1992. Development of Equipment Parameter Tolerances for the Ultrasonic Inspection of Steel Components: Application to Components up to 3 inches Thick. NUREG/CR-5817, Vol 1. Pacific Northwest Laboratory, Richland, Washington.

Doctor, S. R., M. S. Good, P. G. Heasler, R. L. Hockey, F. A. Simonen, J. C. Spanner, T. T. Taylor, and T. V. Vo. 1992. Nondestructive Examination (NDE) Reliability for Inservice Inspection of Light Water Reactors. NUREG/CR-4469, PNL-5711, Vol. 13. Pacific Northwest Laboratory, Richland, Washington.

Doctor, S. R., M. S. Good, P. G. Heasler, R. L. Hockey, F. A. Simonen, J. C. Spanner, T. T. Taylor, and T. V. Vo. 1992. Nondestructive Examination (NDE) Reliability for Inservice Inspection of Light Water Reactors. NUREG/CR-4469, PNL-5711, Vol. 12. Pacific Northwest Laboratory, Richland, Washington.

Doctor, S. R., M. S. Good, E. R. Green, P. G. Heasler, F. A. Simonen, J. C. Spanner, T. T. Taylor, and T. V. Vo. 1991. Nondestructive Examination (NDE) Reliability for Insenvice Inspection of Light Water Reactors. NUREG/CR-4469, PNL-5711, Vol. 11. Pacific Northwest Laboratory, Richland, Washington.

Heasler, P. G., T. T. Taylor, J. C. Spanner, S. R. Doctor, and J. D. Deffenbaugh. 1990. Ultrasonic Inspection Reliability for Intergranular Stress Corrosion Cracks: $A$ Round Robin Stuciy of the Effects of Personnel, Procedures, Equipment and Crack Characteristics.
NUREG/CR-4908. Pacific Northwest Laboratory, Richland, Washington.

Spanner, J. C., S. R. Doctor, T. T. Taylor/PNL and J. Muscara/NRC. 1990. Qualification Process for Ultrasonic Testing in Nuclear Inservice Inspection Applications. NUREG/CR-4882, PNL-6179. Pacific Northwest Laboratory, Richland, Washington.

Doctor, S. R., J. D. Deffenbaugh, M. S. Good, E. R. Green, P. G. Heasler, F. A. Simonen, J. C. Spanner, T. T. Taylor, and T. V. Vo. 1990. Nondestructive Examination (NDE) Reliability for Inservice Inspection of Light Water Reactors. NUREG/CR-4469, PNL-5711, Vol. 10. Pacific Northwest Laboratory, Richland, Washington.

Doctor, S. R., J. D. Deffenbaugh, M. S. Good, E. R. Green, P. G. Heasler, F. A. Simonen, J. C. Spanner, and T. T. Taylor. 1989. Nondestructive Examination (NDE) Reliability for Inservice Inspection of Light Water Reactors. NUREG/CR-4469, PNL-5711, Vol. 9. Pacific Northwest Laboratory, Richland, Washington.

Doctor, S. R., J. D. Deffenbaugh, M. S. Good, E. R. Green, P. G. Heasler, F. A. Sinonen, J. C. Spanner, and T. T. Taylor. 1989. Nondestructive Examination (NDE) Reliability for Inservice Inspection of Light Water Reactors. NUREG/CR-4469, PNL-5711, Vol. 8. Pacific Northwest Laboratory, Richland, Washington.

Doctor, S. R., J. D. Deffenbaugh, M. S. Good, E. R. Green, P. G. Heasler, F. A. Simonen, J. C. Spanner, and T. T. Taylor. 1988. Nondestructive Examination (NDE) Reliability for Inservice Inspection of Light Water Reactors. NUREG/CR-4469, PNL-5711, Vol. 7. Pacific Northwest Laboratory, Richland, Washington.

Doctor, S. R., J. D. Deffenbaugh, M. S. Good, E. R. Green, P. G. Heasler, G. A. Mart, F. A. Simonen, J. C. Spanner, T. T. Taylor, and L. G. Van Fleet. 1987. Nondestructive Examination (NDE) Reliability for Inservice Inspection of Light Water Reactors. NUREG/CR4469, PNL-5711, Vol. 6. Pacific Northwest Laboratory, Richland, Washington.

Doctor, S. R., D. J. Bates, J. D. Deffenbaugh, M. S. Good, P. G. Heasler, G. A. Mart, F. A. Simonen, J. C. Spanner, T. T. Taylor, and L. G. Van Fleet. 1987. 
Previous Reports

Nondestructive Examination (NDE) Reliability for Inservice Inspection of Light Water Reactors. NUREG/CR4469, PNL-5711, Vol. 5. Pacific Northwest Laboratory, Richland, Washington.

Doctor, S. R., D. J. Bates, J. D. Deffenbaugh, M. S. Good, P. G. Heasler, G. A. Mart, F. A. Simonen, J. C. Spanner, A. S. Tabatabai, T. T. Taylor, and L. G. Van Fleet. 1987. Nondestructive Examination (NDE) Reliability for Inservice Inspection of Light Water Reactors. NUREG/CR-4469, PNL-5711, Vol. 4. Pacific Northwest Laboratory, Richland, Washington.

Collins, H. D. and R. P. Gribble. 1986. Siamese Imaging Technique for Quasi-Vertical Type (QVT) Defects in Nuclear Reactor Piping. NUREG/CR-4472, PNL-5717. Pacific Northwest Laboratory, Richland, Washington.

Doctor, S. R., D. J. Bates, R. L. Bickford, L. A. Charlot, J. D. Deffenbaugh, M. S. Good, P. G. Heasler, G. A. Mart, F. A. Simonen, J. C. Spanner, A. S. Tabatabai, T. T. Taylor, and L. G. Van Fleet. 1986. Nondestructive Examination (NDE) Reliability for Inservice Inspection of Light Water Reactors. NUREG/CR4469, PNL-5711, Vol. 3. Pacific Northwest Laboratory, Richland, Washington.

Doctor, S. R., D. J. Bates, L. A. Charlot, M. S. Good, H. R. Hartzog, P. G. Heasler, G. A. Mart, F. A. Simonen, J. C. Spanner, A. S. Tabatabai, and T. T. Taylor 1986. Evaluation and Improvem.2nt of NDE Reliability for Inservice Inspection of Light Water Reactors. NUREG/CR-4469, PNL-5711, Vol. 2. Pacific Northwest Laboratory, Richland, Washington.

Doctor, S. R., D. J. Bates, L. A. Charlot, H. D. Collins, M. S. Good, H. R. Hartzog, P. G. Heasler, G. A. Mart, F. A. Simonen, J. C. Spanner, and T. T. Taylor. 1986. Integration of Nondestructive Examination (NDE) Reliability and Fracture Mechanics, Semi-Annual Report, April 1984 - September 1984. NUREG/CR-4469, PNL5711, Vol. 1. Pacific Northwest Laboratory, Richland, Washington.

Good, M. S. and L. G. Van Fleet. 1986. Status of Activities for Inspecting Weld Overlaid Pipe Joints. NUREG/CR-4484, PNL-5729. Pacific Northwest Laboratory, Richland, Washington.
Heasler, F. G., D. J. Bates, T. T. Taylor, and S. R. Doctor. 1986. Performance Demonstration Tests for Detection of IntergranularStress Corrosion Cracking. NUREG/CR-4464, PNL-5705, Pacific Northwest Laboratory, Richland, Washington.

Simonen, F. A. 1984. The Impact of Nondestructive Examination Unreliabilityon Pressure Vessel Fracture Predictions. NUREG/CR-3743, PNL-5062. Pacific Northwest Laboratory, Richland, Washington.

Simonen, F. A. and H. H. Woo. 1984. Analyses of the Impact of Inservice Inspection Using Piping Reliability Model. NUREG/CR-3869, PNL-5140. Pacific Northwest Laboratory, Richland, Washington.

Taylor, T. T. 1984. An Evaluation of Manual Ultrasonic Inspection of Cast Stainless Steel Piping.

NUREG/CR-3753, PNL-5070. Pacific Northwest Laboratory, Richland, Washington.

Bush, S. H. 1983. Reliability of Nondestructive Examination, Volumes $1, I I$, and III. NUREG/CR-3110-1, -2, and -3; PNL-4584. Pacific Northwest Laboratory, Richland, Washington.

Simonen, F. A. and C. W. Goodrich. 1983. Parametric Calculations of Fatigue Crack Growth in Piping. NUREG/CR-3059, PNL-4537. Pacific Northwest Laboratory, Richland, Washington.

Simonen, F. A., M. E. Mayfield, T. P. Forte, sad D. Jones. 1983. Crack Growth Evaluation for Small Cracks in Reactor-Coolant Piping. NUREG/CR-3176, PNL-4642. Pacific Northwest Laboratory, Richland, Washington.

Taylor, T. T., S. L. Crawford, S. R. Doctor, and G. J. Posakony. 1983. Detection of Small-Sized Near-Surface Under-Clad Cracks for Reactor Pressure Vessels.

NUREG/CR-2878, PNL-4373. Pacific Northwest Laboratory, Richland, Washington.

Busse, L. J., F. L. Becker, R. E. Bowey, S. R. Doctor, R. P. Gribble, and G. J. Posakony. 1982. Characterization Methods for Ultrasonic Test Systems.

NUREG/CR-2264, PNL-4215. Pacific Northwest Laboratory, Richland, Washington. 
Morris, C. J. and F. L. Becker. 1982. State-of-Practice Review of Ultrasonic In-senvice Inspection of Class I System Piping in Commencial Nuclear Power Plants. NUREG/CR-2468, PNL-4026. Pacific Northwest Laboratory, Richland, Washington.

Becker, F. L., S. R. Doctor, P. G. Heasler, C. J. Morris, S. G. Pitman, G. P. Selby, and F. A. Simonen. 1981. Integration of NDE Reliability and Fracture Mechanics, Phase I Report. NUREG/CR-1696-1, PNL-3469. Pacific Northwest Laboratory, Richland, Washington.

Taylor, T. T. and G. P. Selby. 1981. Evaluation of ASME Section XI Reference Level Sensitivity for Initiation of Ultrasonic Inspection Examination.

NUREG/CR-1957, PNL-3692. Pacific Northwest Laboratory, Richland, Washington. 


\section{Acronyms}

\begin{tabular}{|c|c|c|c|}
\hline $\mathrm{AC}$ & Alternating Current & ISI & Inservice Inspection \\
\hline ADS & Automatic Depressurization System & LOCA & Loss-of-Coolant Accident \\
\hline A-E & Architect-Engineer & LP & Low Pressure \\
\hline AFWS & Auxiliary Feedwater System & LPI & Low-Pressure Injection System \\
\hline ANS & American Nuclear Society & LWR & Light Water Reactor \\
\hline ASME & American Society of Mechanical Engineers & MFW & Main Feedwater System \\
\hline ATWS & Anticipated Transients Without Scram & NDE & Nondestructive Evaluation \\
\hline $\mathrm{B} \& W$ & Babcock \& Wilcox & NRC & Nuclear Regulatory Commission \\
\hline BWR & Boiling Water Reactor & NSSS & Nuclear Steam Supply System \\
\hline $\mathrm{CC}-1$ & Calvert Cliffs, Unit 1 & PCS & Power Conversion System \\
\hline $\mathrm{CCW}$ & Component Cooling Water & PNL & Pacific Northwest Laboratory \\
\hline CDS & Condensate System & PORV & Power-Operated Relief Value \\
\hline $\mathrm{CE}$ & Combustion Engineering & PRA & Probabilistic Risk Assessmient \\
\hline $\mathrm{CPC}$ & Charging Pump Cooling & PSAR & Preliminary Safety Analysis Report \\
\hline CR-3 & Crystal River, Unit 3 & PWR & Pressurized Water Reactor \\
\hline DC & Direct Current & $\mathrm{RCIC}$ & Reactor Core Isolation Cooling \\
\hline $\mathrm{DH}$ & Decay Heat & RCP & Reactor Coolant Pump \\
\hline ECCS & Emergency Core Cooling System & RCS & Reactor Coolant System \\
\hline ES & Engineered Safeguard & RPS & Reactor Protection System \\
\hline ESW & Emergency Service Water System & RPV & Reactor Pressure Vessel \\
\hline & Final Safety Analysis Report & RSSMAP & $\begin{array}{l}\text { Reactor Safety Study Methodology Applica- } \\
\text { tion Program }\end{array}$ \\
\hline $\mathrm{FW} / \mathrm{CDS}$ & $\mathrm{F} \cdot \mathrm{dwater} /$ Condensate System & $\mathrm{SG}$ & Steam Generator \\
\hline FWS & Feedwater System & & \\
\hline GE & General Electric & & Generator Tube Rupture \\
\hline HP & High Pressure & S\&L & Sargent \& Lundy Engineers \\
\hline HPI/R & High-Pressure Injection or Recirculation & SLC & Standby Liquid Control \\
\hline $\mathrm{HPCl}$ & High-Pressure Coolant Injection & SIT & Safety Injection Tanks \\
\hline HPI & High-Pressure Injection & SPC & Suppression Pool Cooling \\
\hline IDCOR & Industry Degraded Core Rulemaking & S\&W & Stone \& Webster \\
\hline IPE & Individual Plant Examination & SWS & Service Water System \\
\hline IREP & Interim Reliability Evaluation Program & W & Westinghouse \\
\hline
\end{tabular}




\subsection{Introduction}

A multi-year program entitled Evaluation and Improvement of Nondestructive Examination Reliability for the Inservice Inspection of Light Water Reactors (NDE Reliability Program) was established at the Pacific Northwest Laboratory (PNI) for the Nuclear Regulatory Commission (NRC) to determine the reliability of current inservice inspection (ISI) techniques and to develop recommendations that would ensure a suitably high inspection reliability if fully implemented. Goals of the NDE Reliability Program are to assess current ISI techniques and requirements of all pressure boundary systems and components, determine if improvements are needed and if necessary, develop recommendations for revising the ASME Code and regulatory requirements. In meeting the program objectives many activities have been conducted to develop the necessary technical data bases to formulate positions. One of the important aspects of conducting ISI is to have an inspection plan that is optimized to provide effective inspections at the right locations with the proper inspection frequency to reliably detect and accurately size any flaws of importance to structural integrity.

ASME Section XI currently prescribes priorities for the inspection of pressure boundary systems and components. These priorities are set in accordance with the Class 1, 2, and 3 designations used in the original design and construction of the plant. For example, the reactor pressure vessel is a Class 1 component and receives the highest level of inspection (volumetric examination), whereas a Class 3 piping system would receive a much lower level inspection (visual examination).

In evaluating approaches that could be used to provide tiie technical rationale for improved inspection plans, PNL has developed and applied a method that uses the results of probabilistic risk assessment (PRA) to establish risk-based systems for ISI requirements (Vo et al. 1989a). In the PNL program, the feasibility of developing risk-based generic ISI requirements are being developed in two phases. Phase I focuses on identifying generic inspection requirements for the risk-important systems. It consists of activities to identify and prioritize systems relevant to plant safety. In this phase, PNL establishes the extent to which generic insights drawn from the selected plants can be extrapolated to different classes of LWRs. The results of these activities will be consolidated into a program plan for com- prehensive component inspection that will take place in Phase II.

PRA-based information is being used in a number of regulatory programs sponsored by the NRC. One of the promising programs involves the use of PRAs in inspections of nuclear power plants. In that program, work focuses on the use of PRA-based information to assist the resident inspector in identifying risk-important systems, components, and procedures (Vo et al. 1989b). The NRC Region I office has been using PRA-based information to assist in inspections through the use of PRA-assisted team inspections and PRA checklists. Their conclusions were that the PRA-based information provides an effective tool in planning and performance of inspections.

The results of this report should be viewed as an important contribution to the area of risk-based inspection requirements, which is subject of growing interest to the NRC, the electric power industry, and professional organizations, such as the ASME. In this regard, priorities for ISI as given in ASME Section XI have historically been based on qualitative considerations of risk. However, current requirements were adopted many years ago without the benefit of the PRA methods which are now available to quantify risks.

In recognition of a need to review and update ISI requirements, ASME has formed a Research Task Force on Risk-Based Inspection Guidelines. This task force will review available methods and data that have been developed and applied in various industry (i.e., aerospace, civil, petrochemical, and others), and will make recommendations for possible changes to ASME Section XI. The NDE Reliability Program at PNL is currently interacting with this task force, by providing data (such as given in this report), which can support recommendations for improved inspection requirements.

This document presents the PNL Phase-I results of evaluations for plants selected for the study. Chapter 2.0 presents the overall method for plant system prioritization and selection. The plants selected for the feasibility study are presented in Chapter 3.0. The analyses and results of these plants are given in Chapter 4.0. The results establishing the feasibility of developing generic risk-based rankings of pressure boundary systems for inspection are summarized in Chapter 5.0. 


\subsection{Introduction}

Finally, the summary and conclusions of the study are discussed in Chapter 6.0. 


\subsection{Overall Methodology}

This chapter presents methods used for identifying and prioritizing the most risk-important systems for inspection. The Inspection Importance parameter developed from previous PNL study was also used to prioritize and identify systems. This involves the calculation of certain risk-importance parameter(s) for each system (e.g., Birnbaum Importance Measure) from information in the PRAs and the estimation of system pipe-failure probabilities. Recently developed PRAs selected from among the four reactor vendors in the United States were used to evaluate risk importance measures. Historical pipe-failure data were used to estimate system pipe-failure probabilities. The systems of interest in this study are those required to perform under normal and accident conditions, or that have potential influence on plant safety.

Section 2.1 defines the Inspection Importance Measure. Equations for calculating the Birnbaum Importance Measure for plant systems and data for system failure probabilities (caused by pipe failure) are summarized in Sections 2.2 and 2.3 , respectively. The present methodology is essentially the same methodology described in a previous PNL publication (Vo et al. 1989a).

\subsection{Inspection Importance}

The Weld Inspection Importance Measure (Vo et al. 1989a) was used to rank systems for this study. The Weld Inspection Importance Measure ( $\left.\mathrm{I}^{\mathrm{W}}\right)$ for a given system is defined as the product of the Birnbaum times the pipe failure probability $\left(P_{\delta}\right)$ for that system:

$$
I^{\omega}=I^{B} * P
$$

In this application, $\mathrm{I}^{\mathrm{w}}$ can be interpreted to be a measurement of the risk that an accident caused by pipe failure will occur. Physically, $I^{\mathrm{w}}$ is an approximation of the core melt risk due to system and/or component failures caused 'y pipe failures. Equation 2.1 may be more broad applied to pipe cracking, wall thinning, and other failure modes for pressure boundary systems and components as well as weld failures. Therefore, $I^{\mathbf{w}}$ in this report is referred to more generally as an Inspection Importance Measure rather than specifically as the Weld Inspection Importance Measure.

\subsection{Birnbaum Importance Measure}

The concept of core damage is the central focus of the Birnbaum Importance Measure. Core-damage frequency was used in this study as the bottomline risk measure to prioritize the plant systems. The term core damage in the context of this report refers to an accident during which a combination of equipment failures and personnel errors lead to an uncovering of the reactor core and sustained loss of core cooling.

In PRA analyses, accident sequences that can result in core damage are delineated using event trees to model success and failure of all the functions necessary to maintain core cooling. These accident sequences and their associated probabilities and/or frequencies are used to calculate the system importances. If the risk measure is defined to be the accident sequence (or cut set) core damage freçuency then the Birnbaum Importance Measure for component $i\left(I_{i}{ }^{B}\right)$ can be expressed as:

$$
I_{i}^{D}=R_{i}^{*}-R_{t}^{-}
$$

where $R_{t}^{+}=$cut set frequency with component i assumed failed

$$
R_{i}^{-}=\text {cut set frequency with component } \mathrm{i}
$$
assumed working perfectly.

The sum of the $\mathrm{I}^{\mathrm{B}}$ for components is then the $\mathrm{I}^{\mathrm{B}}$ for the given system (a series system is assumed). The interpretation of Birnbaum Importance Measure is the change in risk that is associated with a system failure. When risk is measured by core damage frequency, the $I^{B}$ of a system is equivalent to the conditional probability of core damage given a system failure ( $R_{l}^{*}$ is numerically equal to the normalized conditional probability and $R_{i}^{-} \ll R_{i}^{+}$). In order to obtain more information concerning the Birnbaum Importance Measure for a given system, Equation (2.2) was manipulated to obtain useful relationships among other importance measures (e.g., the risk increase and the risk reduction importance measures). 


\subsubsection{Risk Increase}

The risk increase is defined (Vesely et al. 1983) to be the increase in risk if the component or system were assumed not to be there or to be failed. On an interval scale the risk increase, $A$, of component $i$ is defined as:

$$
A_{i}=R_{i}^{+}-R_{0}
$$

where $R_{t}^{+} \quad$ is the increased risk level without component $i$ or with component $i$ assumed failed

$R_{\text {. }} \quad$ is the present risk level

\subsubsection{Risk Recuction}

Similarly, the risk reduction is defined to be the decrease in risk if the component $i$ was assumed to be optimized or was assumed to be made perfectly reliable. In terms of an interval scale, the risk reduction, $D_{i}$ is:

$$
D_{1}=R_{\bullet}-R_{i}^{-}
$$

where $R_{0} \quad$ is the present risk level

$R_{i}^{-} \quad$ is the decreased risk level with the component optimized or assumed to be perfectly reliable.

By adding and subtracting the present risk level $R_{0}$ to the right side of Equation (2.2) it can be seen that:

$$
I_{i}=A_{i}+D_{i}
$$

Thus, the Birnbaum importance is the sum of the well known risk increase and reduction importances of component $i$ on an interval scale. Evaluation of system prioritization using the Birnbaum Importance Measure is readily accomplished by utilizing Equation 2.5 and the results of the PRA, (i.e., the sum of $A$ and $D$ for all system components is then I for the given system.)
The risk increase and the risk reduction importances convey information in a different manner than the Birnbaum Measure. In general, for highly reliable systems, $\mathbf{R}_{i}^{+}$is much larger than $\mathbf{R}_{\mathrm{o}}$ or $\mathbf{R}_{\mathbf{i}}^{-}$. For these systems, $R_{i}^{+}$and $A_{i}$ are approximately equal to $I_{i}{ }^{B}$.

Calculation of the risk importances as a standard application part of a PRA is straightforward. Most of the information needed to calculate the risk importances is available from a PRA. The success requirements, the initiating event frequencies, the system and component unavailabilities, the assumed human actions, and the system dependencies for each sequence are quantified when performing the PRA. The risk reduction is calculated by reevaluating the Boolean equations substituting zero for the unavailability of the event of interest. The risk increase is calculated by substituting a value of unity to the unavailability of the component of interest. For subsystems or systems, similar types of manipulations and evaluations would be performed.

\subsection{Piping System Failure Probability}

The piping system failure probabilities estimated in a previous study (Vo et al. 1989a) were used. In summary, the estim: "es were based on the historical pipe failure frequency data in commercial U.S. nuclear power plants repo.ted in NUREG/CR-4407 (Wright et al. 1987). For the systems of interest, the probability of piping system failure or its unavailability was estimated. For this particular application, the piping system unavailability was estimated. A pipe failure is assumed to be detected by periodic monitoring or testing of the system. In mathematical terms, the pipe-failure probability of system $\left(P_{i}\right)$, is defined as:

$$
P_{1}=\lambda_{f}
$$

where $\lambda_{i}$ is the estimated pipe failure rate for system $i$ and $t$ is the assumed test interval, typically 10 years for most piping systems.

The above approach excluded the probability of piping system failure by indirect effects (e.g., caused by failures of other systems in the zone of interest) due to their small contributions. Pipe failure in the present context implies a total pipe break or leak of sufficient magnitude that the system cannot perform its intended 
safety function. As a point of clarification "pipe" failures as discussed within this report will often take on an expanded definition beyond strictly piping in its usual sense, and will also include the vessels, steam generator tubing and other pressure boundary components that are associated with the piping systems of interest.

Table 2.1 shows the estimated unavailabilities for various PWR piping systems. Using the pipe failure frequencies for BWR systems reported in NUREG/CR4407, the estimated unavailabilities for various BWR piping systems are presented in Table 2.2. To estimate the piping system failure probabilities, the numbers in Tables 2.1 and 2.2 should be multiplied by a factor of two. In addition, the failure probabilities over the inspection interval can be normalized by dividing by $t$ to yield the failure probabilities per unit time. The tabulated probabilities are generic values as averaged for all PWR and BWR plants. Meaningful plant-specific failure probabilities could not be estimated due to the sparse nature of the historical occurrence of pipe failures.

Table 2.1. Estimated Unavailabilities for PWR Systems ${ }^{(a)}$

\section{System}

System Unavailability

Steam Generator (SG)

Due to Pipe Failures
Table 2.2. Estimated Unavailabilities for BWR Systems ${ }^{(a)}$

System Unavailability

System Due to Pipe Failures

Feedwater/Condensate (FW/CD)

2.4E-03

High Pressure Coolant Injection (HPCI)

Emergency Service Water (ESW)

Reactor Coolant (RCS)

$1.2 \mathrm{E}-03$

$5.9 \mathrm{E}-04$

1.3E-04

Standby Liquid Control (SLC)

Reactor Core Isolation Cooling (RCIC)

$1.3 \mathrm{E}-04$

Power Conversion (PCS)

$1.3 \mathrm{E}-04$

Reactor Pressure Vessel (RPV) 5.0E-06

(a) Vo et al. 1989a.
$1.2 \mathrm{E}-02$

9.5E-04

$3.8 \mathrm{E}-04$

$3.8 \mathrm{E}-04$

4.7E-05

4.7E-05

4.7E-05

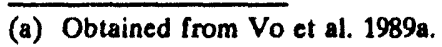




\subsection{Plants Selection Process for Feasibility Study}

This chapter discusses the plant selection process used for this study. The discussion includes the criteria used to select the plants, and the identification of plants with similar designs. The selection process began with a review of commercial LWRs designed by the four reactor vendors in the United States. There are approximately 118 nuclear power plants currently operable or under construction in the United States (ANS 1988). This excludes the Fort St. Vrain (a high-temperature gas-cooled reactor), or plants with indefinite operation date (e.g., TMI-2, etc). Currently, two types of nuclear power plants play the major role in nuclear power generation in the United States: pressurized water reactors (PWRs) and boiling water reactors (BWRs). These plants use light water as both coolant and moderator. These power plants are highly complex systems, and it is not practical to treat them in great detail in this report. Consequently, descriptive material about these power plant concepts are summarized in the following paragraphs. For more complete descriptions of nuclear power plants, interested readers are urged to consult the references, power plant Preliminary Safety Analysis Reports (PSARs), or the Final Safety Analysis Reports (FSARs).

\subsection{Selection Criteria}

The characteristics addressed in the selection process included 1) the reactor vendor, 2) the vendor's plant type, 3) the architect-engineer (A-E), and 4) the availability of a state-of-the-art PRA. In some cases, it is not possible to identify features that may influence the inspection process because detailed vendor-specific and/or plant-specific information was not readily available. The primary objective criteria was to select a range of plant characteristics that would be representative of all plants.

\subsubsection{Reactor Vendor Consideration}

Of the 118 plants in the United States, approximately 46 percent were PWRs designed by Westinghouse. The operating power for these plants ranges from $436 \mathrm{MWe}$ to $1250 \mathrm{MWe}$. The Combustion Engineering design is about 13 percent, with operating power range from $478 \mathrm{MWe}$ to $1221 \mathrm{MWe}$. The Babcock and Wilcox design contributed about 8 percent, with an average operating power of approximately $800 \mathrm{MWe}$. And finally, approximately 33 percent of plants are BWR designs by General E"ectric with an operating power ranging from $504 \mathrm{MWe}$ to $1142 \mathrm{MWe}$. The number of plants by each vendor are shown below.

\begin{tabular}{||l|c|}
\hline \multicolumn{1}{|c|}{ Reactor Supplier } & $\begin{array}{c}\text { Number of } \\
\text { Plants }\end{array}$ \\
\hline Westinghouse & 54 \\
\hline Combustion Engineering & 15 \\
\hline Babcock \& Wilcox & 10 \\
\hline General Electric & 39 \\
\hline \multicolumn{1}{|c|}{ Total } & 118 \\
\hline
\end{tabular}

Babcock and Wilcox, Combustion Engineering, and Westinghouse are the three vendors supplying PWR nuclear steam supply systems (NSSS) in the United States. These three NSSSs are somewhat similar with the exception that the Babcock and Wilcox system uses once-through steam generators for their boilers while the other vendors employ recirculating boiler (vertical U-tube) steam generators. The NSSS consists of the reactor vessel, a pressurizer, and two or more primary coolant loops with associated reactor coolant pumps and steam generators. To achieve high core outlet temperatures without boiling, the coolant must be maintained at high pressure, typically about 2200 psia. This mandates that the reactor be contained in a thickwalled steel vessel. The NSSS is totally enclosed within a containment building to prevent radiation leakage to the environment in case of an accident. Except for the steam generators, the secondary system is external to the containment building and consists of the turbinegenerator, condenser, fe ..twater heaters, feed pumps, and piping.

The BWRs designed by General Electric operate with a reactor vessel pressure that is considerably lower than for PWRs. Although the two systems have comparable core outlet temperatures (of about $600^{\circ} \mathrm{F}$ ), the BWR is operated at the coolant saturation pressure. As a result, the BWR reactor vessel is substantially thinner than that of a PWR. On the other hand, the placement of the steam separation equipment results in the BWR vessel having a substantially larger volume. The NSSS for BWRs differs from PWRs in that steam is produced 
within the core and fed directly to the turbine-generator. Consequently, this system uses a direct cycle as opposed to the indirect cycles used with other nuclear power plants. An advantage of BWRs is that the direct cycle eliminates the need for steam generators. An additional feature is that most of the energy transfer in the core is by latent heat as opposed to sensible heat in other nuclear power plants. This allows smaller flow rates. These advantages are offset by the radioactive contamination of the steam which requires additional shielding for the piping, turbine, and feedwater heaters.

\subsubsection{Vendor Plant Type}

For a given reactor vendor, the specific reactor or plant types were considered for the Westinghouse and General Electric designs. For the PWRs designed by Combustion Engineering and Babcock and Wilcox, a preliminary review of plant FSARs indicated that no typespecific classification cxists for those plants. The following paragraphs summarize reactor types classified on the basis of plant operation developed by the U.S. reactor vendors.

To address the most significant difference in plant design configuration, Westinghouse has divided their plants into low-pressure (LP) and high-pressure (HP) versions. The reference plant (HP or LP) is defined in terms of 25 separatc plant systems. Each system is defined to the extent necessary to maximize technical guidance with respect to system operation in response to an emergency transient and to maximize the generic applicability of that technical guidance. The HP version is applicable to plants designed with a safety injection system shutoff pressure greater than the reactor coolant system pressurizer power-operated relier valve (PORV) pressure setpoint. The HP plants utilize the charging pumps as safety injection pumps. The HP reference plant is basically a four-loop plant with system design features similar to current Westinghouse-design plants.

The LP version is designed with a safety injection system shutoff pressure less than the reactor coolant system PORV pressure setpoint. LP plants do not utilize the charging pumps as safety injection pumps. The LP reference plant is basically an "n-loop" plant system with features similar to earlier Westinghouse two-loop plants.
Of the 54 PWRs designed by Westinghouse, approximately 48 are categorized as the HP plants, and approximately 6 are categorized as the LP plants. All $6 \mathrm{LP}$ plants operate at low power (on the order of $500 \mathrm{MWe}$ ) and have been commercially operated for almost 20 years.

The General Electric BWR has evolved through six stages (e.g., BWR/1 through BWR/6). BWR/1 used internal steam separation. It was followed by the $B W R / 2$, the first large direct cycle reactor. The major improvements in the BWR $/ 3$ design were the application of the first jet pump and the improved emergency core cooling spray (ECCS) and reflood systems. The BWR $/ 4$ design increased the core power density 20 percent. In the BWR/5 design, the ECCS systems were improved, and valve flow control was implemented. The later designs (BWR/6) included increased power production. Also the recirculation lines were reduced in size, either through the use of jet pumps or elimination of recirculation lines by placing the recirculation pump impellers within the reactor vessel.

The General Electric BWRs can be characterized as three types: 1) the Type 1 plant is basically a BWR with system design features similar to earlier BWR/1 and BWR/2 plants; Type 2 is a BWR system with design features similar to $B W R / 3$ and $B W R / 4$; and Type 3 is basically a BWR with design features similar to current BWR $/ 5$ and $B W R / 6$ plants. Of the 39 BWRs designed by General Electric, approximately 10 are classified as Type 3 plants, 27 are classified as Type 2 plants, and 2 are classified as Type 1 plants.

It appears that, for the Westinghouse and General Electric plants, the designs and operation of plant systems are essentially the same for plants from the same vendor's plant type. For PWRs designed by Combustion Engincering and Babcock and Wilcox, the designs and operation of plant systems are, in general, essentially the same for all plants from the same vendor. Differences in fuel design, power shaping, and operational history are minor in comparison with support system designs.

\subsubsection{Architect-Engineer Consideration}

Because of design differences involving ancillary support systems for the various engineered safety features and 
the differences in details of containment design, the selection process considered the A-E. At least twelve A-E firms have been involved in the design of nuclear plants in the United States (ANS 1988). The Bechtel Corporation, Sargent and Lundy, and Stone and Webster have designed approximately 61 percent of the nuclear plants in the United States. The number of plants by each of these three are:

\begin{tabular}{||l|c|}
\hline \multicolumn{1}{|c|}{ A-E } & $\begin{array}{c}\text { Number of } \\
\text { Plants }\end{array}$ \\
\hline Bechtel Corporation & 45 \\
\hline Sargent \& Lundy & 17 \\
\hline Stone \& Webster & 14 \\
\hline
\end{tabular}

Site-specific requirements and differing utility requirements often lead to significant differences in support system designs (e.g., AC power, DC power, service water, etc.) The collective results showed variability in design detail from plant to plant. However, the support systems would be expected to be similar for plants for the same vendor, vendor type, and architect-engineer as long as the design parameters are essentially the same, such as coolant pump seal cooling, diesel generator dependencies, etc. Support system functional abilities are essentially the same for all plants from the same product line of a NSSS vendor. However, because the support system designs are not standardized and since the differences in design could impact the models of core damage frequency, care must be taken in extrapolating the results of one plant to another among the same NSSS vendor, vendor type, and A-E.

The selection process also considered differences in containment design. The distinctly different containment designs were an important factor in selection since it was known that containment design differences have a major effect on core damage frequency and, in turn, plant risk. Containment design parameters vary substantially among A-Es and may vary between plants sharing a common site. Because these designs are not standardized, care must be taken in extrapolating the results of one plant to another from the same NSSS supplicr and of the same containment design. Extrapo- lating within a containment group is of moderate validity, but plant-specific details are needed. Extrapolating from one containment group to another is not valid.

Generally, the containment volumes are roughly similar within each of the six containment groups (PWR: large dry, subatmospheric, ice condenser; BWR: Mark I, Mark I, Mark III) and each group has roughly similar volume-to-power ratios although the actual volumes differ in detail, and considerable variations exist in large, dry containments. Within the three BWR containment groups, the volumes vary less from plant to plant than for the PWR groups.

Containment failure modes differ significantly from one containment to another, but within a given containment group these will be more nearly sirnilar than from one group to the next. However, plant-specific features such as penetrations, liner-concrete characteristics, rcinforcement design, and basemat-building connection make each containment different. For BWRs, failure modes are more similar within each group than for the PWRs but can be influenced by structural details. Spray removal effectiveness, ice bed decontamination, and suppression pool decontamination would all be expected to be similar for different plants as long as the design parameters are essentially the same, such as spray height, spray flow rate, and vent submergence. For PWRs, failure modes can be greatly influenced by containment types and structural details. However, for the same containment type, the designs would be expected to be similar for different plants as long as the design parameters are essentially the same.

The generic insights presented above are broadly indicative of items that may be applicable within a class of plants or to operating U.S. LWRs as a group. This includes the identification of similarities that may exist in the plant of similar design. These insights cannot be assumed to apply to a given plant without consideration of plant design and operational practices because of design differences that exist in U.S. plants. There could be significant differences among plants due to plantspecific design and procedures differences. Such factors must be evaluated before using these results for attempting to apply the results to other plants. 


\subsubsection{Availability of PRA}

Since the Three Mile Island accident in 1979, over 20 full-scope PRAs have been performed on U.S. plants. The total core damage frequencies for the studies are generally similar. However, the individual contributor frequencies in each study are slightly different. The differences are attributed to design configuration, data selection, or model development. The principal accident contributors are summarized below.

For BWRs, the principal contributors to the likelihood of a core damage accident, considering only internally initiated events, are sequences related to station blackout or anticipated transients without scram (ATWS). However, for some plants, the importance of ATWS sequences or long-term loss of decay heat removal sequences (as well as sequences associated with ATWS events) appears to have been reduced because of modifications to the plants, improved operator understanding, and credit given for alternative means of injecting water to the core. In addition, accident sequences associated with the long-term loss of suppression pool cooling were found less important in recent PRA studies because of improved procedures for coping with accident sequences, including venting of the wetwell above the suppression pool.

The important sequences contributing to the frequency of core damage accidents at PWRs include those initiated by a variety of electrical power system disturbances (loss of single AC bus, loss of off-site power, and complete station blackout), small loss-of-coolant accidents (LOCAs), loss of coolant support systems such as the service water or component cooling system, ATWS, and interfacing-system LOCAs in which reactor coolant is lost into systems that subsequently fail and release the radioactive water outside the containment boundary. The differences among the studies arise from plant differences and modeling improvements for thermalhydraulic considerations, and operator performance that has been gained since the Reactor Safety Study (WASH-1400, NRC 1975). More importantly, design changes, imprroved procedures, and better operator training led to the most significant differences in the results of the various studies.

More recently, the NRC has required utilities to have an individual plant evaluation (IPE) as part of the licensing process. A method has recently been developed under the Industry Degraded Core Rulemaking (IDCOR) program sponsored by the nuclear industry and being carried out by the Atomic Industrial Forum. IDCOR has developed IPE methodologies for both PWRs and BWRs. Test applications of the IPE methodology have been completed for some plants, for instance, for Surry. The IDCOR method not only provides insights concerning the core-damage-frequency importance of events and plant systems but also identifies those systems that may be unique to the plant and thus may affect the comparability of PRA results among plants. When the IPE results for all plants are available, these may be compared to validate the generic applicability of the results of this study.

\subsubsection{Perspectives}

Based on the information presented, the following perspective is provided with respect to extrapolating the results among plants.

1. For PWRs, with an exception of differences in containment designs, Westinghouse-design plants of the same type and A-E may have a similar system functional design. Extrapolation for a given plant to another of the same type and A-E is possible. However, care must be taken for those plants with unusual support system designs (e.g., dependency of the charging pump cooling on the component cooling water system at Zion-1).

2. For Babcock and Wilcox and Combustion Engineering plants, extrapolation for a given plant to another of the same NSSS vendor and A-E can be done with reasonable confidence if care is taken to account for unusual plant-specific differences.

3. For BWRs, with an exception of differences in containment designs, it appears that the designs are more similar within each group than for the PWRs. Extrapolating information about a given plant to another of the same type and the same A-E could be accomplished. Similarly, care must be taken for plants with unusual designs.

Generally, BWR/3 and BWR/4 plant types have similar functional design in the sense of support system operation. Extrapolating these types to another plants is possible; however, some plant-specific information are 
needed. For example, at some BWRs, containment failure is expected to cause the failure of the low-pressure coolant injection systems that take suction from the suppression pools due to saturation of the pool. Diesel generators in some plants are dependent on the station batteries and emergency service water system (e.g., Peach Bottom-2). This is in contrast to other plants that have dedicated batteries for diesel generators and/or self-cooled diesels, thus making the diesel generators independently operable.

Similarly, BWR/5 and BWR/ 6 plant types are somewhat generic and extrapolating between them is possible, however, if care is taken for unusual differences. At some BWRs, the reactor core cooling isolation system will be isolated by a long-term station blackout on high exhaust pressure because of the rising containment backpressure. The venting containment concept has been adopted by a number of plants to improve the availability of these systems.

Several issues associated with the analyses performed in this chapter have been examined for applicability to other plants. Based on the information presented, with the exception of differences in the containment designs, it appears that plants with the same NSSS vendor, type and A-E may have be similar in system design and functionality. However, the qualitative results are highly plant specific; therefore, these results may not be used directly to extrapolate to another plant. For rigorous analysis, plant-specific analysis is needed, but this chapter provides a structure and framework that can be used to improve the efficiency and quality of future analyses.

\subsection{Plants Selected for Study}

Because the scope of the feasibility study does not permit evaluations of all LWRs in the United States, the analyses have focused on inspection requirements for a few well documented plants. Using the discussion in the preceding section, seven plants (in addition to Oconee-3 from the earlier study) were selected for study. These plants are listed in Table 3.1.

The PRA results of the selected plants were compared with the results of other PRA studies of similar plants. Differences were found because the PRAs were developed by different sponsorships and occurred at different times during the development of the PRA methodology. Although the comparison is limited to the dominant accident contributors; a comparison of this type can yield insights into differences between studies.

The Surry-1 PRA was compared with the Millstone-3 PRA. Millstone- 3 is a Westinghouse PWR housed in a subatmospheric containment with emergency core cooling and containment systems similar to those of Surry-1. The PRA was developed by the Northeast Utilities.

The Zion-1 PRA was compared with the IDCOR Zion PRA. The IDCOR Zion PRA was sponsored by the electric utility industry for the Industry Degraded Core Rulemaking Program (IDCOR). The Sequoyah PRA was compared with the RSSMAP Sequoyah PRA. The RSSMAP Sequoyah PRA was developed for the Reactor Safety Study Methodology Application Program (RSSMAP). The Crystal River PRA was compared with the IREP ANO-1 PRA. The ANO-1 PRA was developed for the Interim Reliability Evaluation Program (IREP).

Calvert Cliffs-1 was selected for study because it is the only Combustion Engineering plant with a completed and available PRA. To be generic, the Calvert Cliffs results were compared with the Generic System 80 PRA. The Generic System 80 PRA does not address a specific plant, but was a proprietary study performed by Combustion Engineering to address the NRC Severe Accident Policy Statement for standardized design of future plants. The objectives were to calculate a baseline core damage frequency for a generic System 80 plant, to determine the dominant core damage contributors, and to assess potential areas for design improvement in the future plants.

For BWRs (Peach Bottom-2 and Grand Gulf-1), the PRA results were compared with the Browns Ferry PRA that resulted from the IREP program and the RSSMAP Grand Gulf-1 PRA. Browns Ferry is a General Electric BWR/4 with Mark I containment and the emergency core cooling and containment systems are similar to those of Peach Bottom-2. 
Table 3.1. Plants Selected for Feasibility Study

\begin{tabular}{l}
$\quad$ Plant Name \\
\hline Surry-1 \\
Zion-1 \\
Sequoyah-1 \\
Oconee-3 \\
Crystal River-3 \\
Calvert Cliffs-1 \\
Peach Bottom-2 \\
Grand Gulf-1
\end{tabular}

Vendor/Type/A-E/Containment

W/HP/S\&W/Subatmospheric W/HP/S\&L/Large, Dry W/HP Utility/Ice Condenser B\&W/-/Bechtel-Utility/Large, Dry B\&W/-/Gilbert/Large, Dry CE/-/Bechtel/Large, Dry GE/BWR4/Bechtel/Mark I GE/BWR6/Bechtel/Mark III
PRA Source

NUREG/CR-4550, Vol. 1

NUREG/CR-4550, Vol. 3

NUREG/CR-4550, Vol. 5

NSAC/60-SY

FPC/SAI

NUREG/CR-3511

NUREG/CR-4550, Vol. 4

NUREG/CR-4550, Vol. 6

(a) Completed (NUREG/CR-5272).

The results of the comparison indicate that the total core damage frequencies are similar from all studies for a given plant. However, the individual contributors in each study may differ slightly. The differences are attributed to design configuration, data selection, model development, or initiating event selection. The differences among these studies reflect the improved knowledge of thermal-hydraulic considerations and operator performance that has been gained since the Reactor
Safety Study (NRC 1975). More importantly, design changes, improved procedures, and better operator training lead to the most significant differences in the various studies.

For the plants selected for analyses, the effort focused on internal events that contribute to severe core damage (Level I). This type of analysis will be discussed in the next chapter. 


\subsection{Analyses Of Selected Plants}

This chapter presents analyses of seven plants (five PWRs and two BWRs) to determine system inspection priorities. The plants selected are identified in Table 3.1. Because of differences in reactor design, separate analyses were performed for the PWRs and BWRs. Analyses and results are presented in Sections 4.1 and 4.2 , respectively. To evaluate the differences of system ranking that result between plants, plant-specific insights are provided and discussed for each plant analyzed.

\subsection{Analyses Of Pressurized Water Reactors}

This section addresses the piping system inspection priorities for the five selected PWRs. For each PWR, the analysis includes a brief description of each plant, a summary of accident sequences identified from the PRA, and the system prioritization and selection results.

\subsubsection{Surry Nuclear Power Station Unit 1}

The Surry Nuclear Power Station Unit 1 (Surry-1) is one of a two-unit station, located on the James River near Williamsburg, Virginia. Surry-1 is a Westinghouse-designed three-loop pressurized water reactor rated at 788 MWe capacity with a subatmospheric containment. The balance of plant and the containment building were designed and constructed by Stone and Webster Engineering Corporation. Surry-1 is operated by Virginia Electric and Power Company; commercial operation started in 1972.

\subsubsection{Surry-1 Core Damage Frequency}

The total core damage frequency from internally initiated events was estimated to be $2.6 \mathrm{E}-05$ per plant year (/py) (Bertucio et al. 1986a) with 95 percent and 5 percent upper and lower bounds of 6.7E-05/py and 7.1E-06/py, respectively. The core-damage frequency was dominated by transient-initiated accident sequences. This accounts for approximately 68 percent of the mean of the total core damage frequency. The lesser contributions are from LOCA initiated sequences (both inside and outside containment) which comprise 32 percent of the total core damage frequency.

Of the contribution from transients, station blackout sequences as a group are the largest contributor to core damage frequency ( 38 percent). Station blackout is defined as a loss of all $\mathrm{AC}$ power (except vital AC supplied through DC inverters). This is caused by loss of off-site power and the subsequent failure of both diesel generators. The largest sequence frequency attributed to a station blackout was involved in reactor pump seal LOCA due to the failure of all seal cooling. In this sequence, high-pressure injection and containment systems are unavailable due to the extended unavailability of $\mathrm{AC}$ power. Other core damage sequences resulting from station blackout are the extended unavailability of $\mathrm{AC}$ power and eventual station battery depletion, or failure of the auxiliary feedwater, system in the short term due to failure of the turbine-driven pump.

Core damage sequences resulting from degraded electrical power supplies comprise another 2.5 percent of the total core damage frequency. The dominant sequences in this group involve loss of a $480 \mathrm{~V} \mathrm{AC} \mathrm{elec-}$ trical bus, followed by failure of a pressurizer relief valve to close, and failure of long-term recirculation core cooling due to failure of high-pressure recirculation system or the low-pressure recirculation system. The remaining sequences in this group are initiated by a loss of off-site power, followed by failure of the auxiliary feedwater system and the inability to open both power-operated relief valves (PORVs), thus preventing feed-and-bleed cooling.

LOCA sequences, both inside and outside containment, comprise about one-third of the total core damage frequency. The highest LOCA sequence frequency involves a very small LOCA (equivalent diameter of a break less than $1 / 2$ inch) with failure of high-pressure injection. Other contributors in this group include small-, intermediate-, or large-size LOCAs followed by failure of high-pressure injection or recirculation core cooling. Interfacing system LOCAs comprise 4 percent of the total core damage frequency.

The remaining core damage sequences are those involving failure of the reactor protection system to scram the reactor following a transient -- anticipated transients without scram (ATWS) sequences. These sequences comprise about 6 percent of the total core damage frequency.

Table 4.1 summarizes the contributions to the frequency of core damage from the major sequences for each 
Table 4.1. Dominant Accident Sequences at Surry-1

Sequence

$\mathrm{T}_{1}(\mathrm{SL})-\mathrm{D}_{1} \mathrm{CF}_{1}$

$S_{3} D_{1}$

$\mathrm{T}_{4 \mathrm{~J}} \mathrm{Q}-\mathrm{H}^{1}$

$\mathrm{T}_{4 \mathrm{H}} \mathrm{Q}-\mathrm{H}_{1}$

$\mathrm{T}_{1} \mathrm{~L}(\mathrm{ST}) \mathrm{D}_{1} \mathrm{CF}_{1}$

$\mathrm{T}_{1} \mathrm{~L}(\mathrm{LT}) \mathrm{D}_{1} \mathrm{CF}_{1}$

$T_{1} L P$

TKRD $_{4}$

EVENT-V

$\mathrm{S}_{2} \mathrm{H}_{1}$

$\mathrm{T}_{4} \mathrm{~J} \mathrm{Q}-\mathrm{H}_{2}$

$\mathrm{S}_{1} \mathrm{H}_{1}$

$\mathrm{S}_{1} \mathrm{D}_{1}$

$\mathrm{S}_{2} \mathrm{D}_{1}$

$\mathrm{T}_{4 \mathrm{H}} \mathrm{Q}-\mathrm{H}_{2}$

TKRZ

$\mathrm{AD}_{5}$

$\mathrm{AH}_{1}$

$\mathrm{S}_{2} \mathrm{H}_{2}$

$\mathrm{T}_{1} \mathrm{Q}-\mathrm{D}_{1} \mathrm{CF}_{1}$
Description

Station blackout leading to RCP seal LOCA, followed by failure to restore AC power within $0.5 \mathrm{hr}$ of seal LOCA.

Very small LOCA - Failure of high pressure coolant injection.

Loss of $480 \mathrm{~V}$ Bus $\mathrm{J}$ - Stuck open PORV - Failure to isolate - Failure of low pressure recirculation.

Loss of $480 \mathrm{~V}$ Bus H - Stuck open PORV - Failure to isolate - Failure of low pressure recirculation.

Station blackout - (No seal LOCA) Battery depletion at $4 \mathrm{hr}$ - Nonrecovery AC powa: :ritinin $3 \mathrm{hr}$ of battery depletion.

Station blackout - Failure of AFW to start - Nonrecovery AC power with $0.5 \mathrm{hr}$.

Loss of off-site power - Failure of AFW - Failure to feed and bleed via two PORVs.

ATWS - Failure of manual scram. - Failure of emergency boration.

Interfacing LOCA.

Small LOCA - Failure of low pressure coolant recirculation.

Loss of $480 \mathrm{~V}$ Bus $\mathrm{J}$ - Stuck open PORV - Failure to isolate - Failure of high pressure recirculation.

Medium LOCA - Failure of low pressure coolant recirculation.

Medium LOCA - Failure of coolant injection.

Small LOCA - Failure of coolant injection.

Loss $480 \mathrm{~V}$ Bus H - Stuck open PORV - Failure to isolate - Failure of high pressure recirculation.

ATWS - Failure of manual scram. - Unfavorable MTC results in RCS overpressure.

Large LOCA - Failure of accumulators.

Large LOCA - Failure of low pressure coolant recirculation.

Small LOCA - Failure of high pressure coolant recirculation.

Station blackout - Stuck open PORV (unable to isolate - Nonrecovery

$\mathrm{AC}$ power in $1 \mathrm{hr}$.

Total Core Damage Frequency
Mean Fre-

quency

(per plant

year)

$6.6 \mathrm{E}-6$

2.6E-6

$1.9 \mathrm{E}-6$

$1.6 \mathrm{E}-6$

$1.3 E-6$

$1.3 E-6$

$1.1 \mathrm{E}-6$

$1.1 \mathrm{E}-6$

$9.0 \mathrm{E}-7$

8.9E-7

8.1E-7

7.7E-7

7.1E-7

7.1E-7

$6.8 \mathrm{E}-7$

4.8E-7

3.9E-7

3.2E-7

2.6E-05 
initiating event. Values shown in this table were based on point-estimated sequence frequencies. Together, these sequences contributed about 99 percent of the total core damage frequency.

\subsubsection{Surry-1 System Importance Analysis}

Utilizing the method described in Chapter 2.0 (e.g., Equation 2.1 of Section 2.1) and the results of the Surry-1 PRA, the Inspection Importance for Surry-1 systems were calculated. The Inspection Importance Measure $\left(I^{W}\right)$ for a given system was defined as the product of the system Birnbaum Importance $\left(\mathrm{I}^{\mathrm{B}}\right)$ multiplied times the estimated pipe failure probability $\left(P_{i}\right)$ for that system. The calculations were based on the total core damage frequency (Level-I PRA). The following paragraphs summarize the Surry-1 system $I^{W}$ calculations. Details of the calculations are presented in Appendix A.

The analyses were divided into two steps. The first step in the analysis involves the calculation of Birnbaum Importance Measure for each system from information in the PRA. In the second step, the Inspection Importance Measures for Surry-1 systems are calculated. A LOTUS-based computer code was developed for the analysis.

The Surry-1 PRA contains nine initiating event categories. These range from LOCAs of various sizes inside the containment building, transients involving degraded electrical power supplies, ATWSs, to interfacing system LOCAs. These categories of initiating events together result in 125 dominant accident sequences or cut sets. Of these cut sets, there are 62 cut-set elements that represent failure modes for various plant systems. The frequencies of these cut sets together sum to the total core damage frequency at Surry-1.

Each accident sequence leading to core damage consist of an initiating event and one or more additional elements, each representing either front-line system failures or a recovery element, such as "failure to restore off-site power." For instance, an accident is initiated by a small break in the reactor coolant piping, with a break diameter in the range $1 / 2$ to 2 inches (small LOCA initiating event), followed by failure of the lowpressure recirculation system that provides suction to the high-pressure recirculation system used to cool the core following the initial injection phase (cut set ele- ment). All containment systems are available but the continued heat-up and boil-off of the primary coolant leads to core damage. With a frequency of $8.9 \mathrm{E}-07 / \mathrm{py}$, this sequence contributes about 4 percent to the frequency of core damage.

The calculations began by assigning each of the elements of the cut sets to a preassigned system category number. For instance, all cut set elements associated with the failure of the high-pressure injection system were assigned to a system category 1 (see Appendix A). For each cut set, the calculations were performed for the risk increase, the risk reduction, and the Birnbaum Importance Measures. The risk increase represents the increase in the total cut set frequency if the probability of the event of interest was increased to a value of 1.0 . The risk reduction represents the decrease in the total cut set frequency calculated if the probability of the event of interest were decreased to a value of 0.0 . The Birnbaum Importance is the sum of the risk increase and the risk reduction. The Birnbaum Importance Measure can be interpreted as the change in risk that is associated with a total system failure. When risk is measured by core melt frequency, the Birnbaum Importance of a system is equivalent to the conditional probability of core melt given a system failure.

Calculations of the risk increase or risk reduction are straightlorward. The risk reduction is calculated by reevalual ing the accident sequence substituting zero for the unavailability of the component belonging to the system of interest. The risk increase is calculated by substituting a value of unity for the component unavailability. Evaluation of system prioritization using the Birnbaum Importance Measure is readily accomplished by utilizing Equation 2.5 (i.e., the sum of risk increase and risk decrease for components is then for the given system). The results of the system Birnbaum Importance for Surry-1 are presented in Table 4.2.

It is worthwhile to note that in addition to the CodeType-ISI systems listed in Table 4.2, other systems that are required for the operation of the plant $(A C$ and $D C$ power sources, reactor protection systems, etc.) were also identified and prioritized, but were eliminated from further study since they do not have major pressure boundary functions. 
Table 4.2. Birnbaum Importance Ranking for Surry-1 Systems ${ }^{(a)}$

\begin{tabular}{|c|c|c|}
\hline System & $\mathbf{I}^{\mathbf{B}}$ & Rank \\
\hline Reactor Pressure Vessel (RPV) & 1.0 & 1 \\
\hline Low-Pressure Injection (LPI) & $1.6 \mathrm{E}-02$ & 2 \\
\hline High-Pressure Injection (HPI) & $1.4 \mathrm{E}-02$ & 3 \\
\hline Auxiliary Feedwater (AFW) & $8.2 \mathrm{E}-03$ & 4 \\
\hline Service Water (SWS) ${ }^{(\mathrm{b})}$ & $2.2 \mathrm{E}-03$ & 5 \\
\hline Reactor Coolant (RCS) & $6.1 \mathrm{E}-04$ & 6 \\
\hline Power Conversion (PCS) & $5.1 \mathrm{E}-06$ & 7 \\
\hline Steam Generator (SG) & $5.1 \mathrm{E}-06$ & 8 \\
\hline
\end{tabular}

(a) Only systems of interest to Code-Type-ISI are listed The ranking for the RPV system was assumed to be one for this analysis.

(b) Including contribution of CCW system.

Table 4.3. Inspection Importance Ranking for Surry-1 Systems

\begin{tabular}{||c|c|c||}
\hline System & I $^{\mathrm{W}}$ & Rank \\
\hline HPI & $1.3 \mathrm{E}-05$ & 1 \\
\hline LPI & $6.1 \mathrm{E}-06$ & 2 \\
\hline RPV & $5.0 \mathrm{E}-06$ & 3 \\
\hline AFW & $3.9 \mathrm{E}-07$ & 4 \\
\hline SWS & $1.0 \mathrm{E}-07$ & 5 \\
\hline SG & $5.1 \mathrm{E}-08$ & 6 \\
\hline RCS & $2.9 \mathrm{E}-08$ & 7 \\
\hline PCS & $1.9 \mathrm{E}-09$ & 8 \\
\hline
\end{tabular}

The usefulness of system risk increase and risk reduction results are that they can be used as a guide to prioritize resources in a risk-based inspection program. The features having the highest risk increase are those most important to plant safety. For those features having high risk reduction, activities can focus on modifications of plant operation or designs to reduce the risk to the minimum level. Based on the results of this analysis, the risk increases for Code-Type-ISI systems at Surry-1 with regard to core damage frequency are approximately the same as indicated in Table 4.2 because risk reduction values are much smaller than risk increase values. The systems having the greatest risk reduction values are the RCS, HPI, LPI, and the AFW systems.

From the system Birnbaum Measure results presented in Table 4.2 and the PWR system pipe failure probabilities presented in Table 2.1 (Section 2.3 of Chapter 2), the $\mathrm{I}^{\mathrm{w}}$ for systems were calculated. The $\mathrm{I}^{\mathrm{w}}$ results for various systems at Surry-1 are presented in Table 4.3, ranked in order of decreasing impacts. The HPI is identified as the most important system with respect to pipe failure. The high importance is due to the relatively high pipe failure probability and its important function in providing primary coolant injection and recirculation to the reactor core following an accident.

High risk importances are also noted for the LPI and RPV systems. The high ranking of the LPI system is due to its important function in providing emergency coolant injection and recirculation following a loss of coolant accident and its relatively high system pipe failure probability. For the RPV, the high importance is primarily due to its important function in preventing the reactor core from becoming uncovered following an accident. Failure of the RPV always was assumed to result in core damage.

The AFW and the SWS systems also have relatively high risk with respect to pipe failure. The high importance for the AFW is due to the relatively frequent demand for this system as compared to demand for other systems. The importance of the SWS system is primarily due to its important function in providing cooling to the important front-line systems. The remaining systems (e.g., the RCS and PCS including the steam generator) have lesser importance measures, primarily due to their relatively higher system reliabilities or lower pipe failure probabilities.

\subsubsection{Sensitivity Analyses}

Because of the scope of this study, detailed investigation of the PRAs or of plant-specific system pipe failure 
probabilities were not possible. Consequently, the uncertainties of component unavailabilities, initiating event frequencies, and system pipe failure probabilities and their associated modeling were not addressed. These parameter values were addressed in the PRA of previous studies. In addition, consideration of the functional dependencies and common cause effect on systems are based on the results evaluated by the Surry1 PRA. The mean parameter values estimated by the PRA were used to calculate the system importances.

Sensitivity analyses were only performed on those issues whose potential impact on system ranking was significant. For the Surry-1 study, the sensitivity analyses addressed the effects of significant increases of pipe failure probability. This was accomplished by letting the system pipe failure probabilities approach 1.0. This causes $I^{\mathrm{W}}$ values to be the same as $\mathrm{I}^{\mathrm{B}}$ values, and the new $I^{\mathrm{W}}$ ranking to be the same as the $\mathrm{I}^{\mathrm{B}}$ ranking shown in Table 4.2. The system that led to largest increase in ranking was the RPV, a rank of 1 , an increase of 2 in system ranking. The system having the greatest reduction in ranking was the HPI, a decrease of 2 in system ranking. Other systems remain at the same relative ranking.

The following plant-specific insights were obtained from the Surry-1 PRA. They may affect the system ranking results between Surry-1 and other plants:

\section{Service Water/Component Cooling Water System Availability}

Surry-1 has a unique service water system (i.e., it is gravity fed through the intake canal) that could cause complications because the pumps that normally provide makeup water to the intake canal are unavailable during a station blackout. In addition, there is potential for biofouling of the piping system that serves the important front-line or support equipment. However, this was shown by the Surry-1 PRA not to be a dominant core damage contributor.

Surry-1 is not as susceptible to loss of component cooling water scenarios as some other plants. The reason for this is that at Surry-1, there are two diverse and independent methods for providing reactor coolant pump seal cooling. The component cooling water system can provide seal cooling via the thermal barrier heat exchanger, or the charging system can provide seal cooling via seal injection flow. In addition, the charging system has its own dedicated cooling water system that is independent of the component cooling water system. The only common support systems are AC and DC power. Seal LOCAs, therefore, become important at Surry-1 only in station blackout sequences.

\section{Steam Binding of AFW Pumps}

Operating experience of AFW pumps at Surry indicated that a problem with steam binding of AFW pumps had occurred due to back-leakage of main feedwater through the system check valves. The back-leakage resulted in steam accumulation on the AFW lines and unavailability of two pumps. Since the event, the affected check valves were rebuilt and plant changes were made, including removal of the insulation from the AFW pump discharge lines to facilitate steam condensation. In addition, a check of pump outlet pipe temperature is made once every shift. However, due to the potential for common-cause multiple pump failures this failure mode has been included in the system model.

\subsubsection{Zion Nuclear Power Plant Unit 1}

Zion Nuclear Power Plant Unit 1 (Zion-1) is one of a two-unit station, located near Waukegan, Illinois, Zion-1 is a Westinghouse-designed four-loop PWR rated at $1040 \mathrm{MWe}$ capacity with a large, dry containment. The balance of the plant and the containment building were designed and constructed by Sargent \& Lundy Engineers. Zion-1 is operated by Commonwealth Edison Company, and started commercial operation in 1973.

\subsubsection{Zion-1 Core Damage Frequency}

The total core damage frequency-from internally initiated events was estimated to have a point estimate of $1.5 \mathrm{E}-04 /$ py (Berry et al. 1984). No error bounds associated with the core damage frequency were developed. Accidents initiated by loss of component cooling water or service water system are the largest single group, making up about 79 percent of the total core damage frequency; LOCA initiated events represent about 18 
percent of the core damage frequency, and loss of electrical supplies (on-site and off-site) contribute the remaining 3 percent of the total core damage frequency.

At Zion-1, as modeled, the loss of component cooling water sequence is by far the largest contributor to the total core damage frequency. Loss of component cooling water results in unavailability of the centrifugal pumps and loss of cooling to the reactor coolant pump thermal barriers. This leads to failure of both methods of pump seal cooling, resulting in a seal LOCA. Loss of component cooling also leads to failure of the safety injection system, thereby causing a loss of all emergency core cooling in response to the LOCA. The dominant cause of failure of the $\mathrm{CCW}$ is a pipe rupture. Other failure mechanisms related to the $\mathrm{CCW}$ were insignificant. This sequence led to core damage unless core cooling is restored to the safety injection pumps within about 45 minutes of its initial loss.

LOCA sequences, both inside and outside containment, comprise about one-fifth of the total core damage frequency. The highest LOCA sequence frequency involves a small LOCA, followed by failure of the highpressure recirculation system that cools the core by providing flow from the containment sump. Other contributors in this group include large and intermediate LOCAs followed by failure of low-pressure injection or recirculation core cooling. Interfacing system LOCAs comprise a small percentage of the total core damage frequency.

Of the contribution from transients, station blackout sequences as a group comprise 2 percent of the total core damage frequency. The core damage resulting from station blackout was caused by failure of the turbine-driven auxiliary feedwater pump to provide feedwater or reactor pump seal LOCA due to the extended loss of seal cooling. One percent of the total core damage frequency is due to the loss of off-site power, followed by partial failure of the on-site AC power system. Core damage in these sequences is caused by failure of auxiliary feedwater followed by failure of feed-and-bleed cooling.

Table 4.4 summarizes the contributions to the frequency of core damage from the major sequences for each initiating event. Values shown in this table were based on point-estimated sequence frequencies. Together, these sequences contributed about 99 percent of the total core-damage frequency.

\subsubsection{Zion-1 System Importance Analysis}

At present, the Zion-1 PRA contains five initiating event categories. They ranged from LOCAs of various sizes inside the containment building, loss of component cooling water or service water, to transients involving degraded electrical power supplies. These categories of initiating events together yield 84 cut sets. The frequencies of these cut sets together sum to a total core damage frequency of $1.5 \mathrm{E}-04 / \mathrm{py}$ at Zion-1.

Using the method discussed in the preceding section, the risk increase, the risk reduction, the Birnbaum Importance, and the Inspection Importance Measures for systems at Zion-1 were calculated. Again, the calculations were based on the total core damage frequency (Level I PRA). The results of the calculation indicate that systems that have the greatest risk increase with regard to core damage frequency are the reactor pressure vessel, the SWS, and the reactor coolant systems. The systems found to cause the greatest reduction in core damage frequency, if their probabilities are significantly reduced, are the SWS and the high-pressure injection systems.

The results of the system Birnbaum Importance ranking for the Zion-1 plant are presented in Table 4.5. It is important to note that, in the Zion-1 PRA analyses, accident sequences that resulted from failures of the power conversion system, including the steam generators, were excluded from the analysis because they are quantitatively insignificant compared with SWS failure. Therefore, the rankings for these systems were assumed to be the same as for the Surry-1 plant for the purpose of this analysis.

The $\mathrm{I}^{\mathrm{w}}$ for systems were then calculated using the Birnbaum Measure results in Table 4.5 and the PWR system pipe failure probabilities presented in Table 2.1 (Section 2.3 of Chapter 2). The $\mathrm{I}^{\mathrm{w}}$ for systems are presented in Table 4.6, ranked in order of decreasing impacts.

At Zion, as modeled, the SWS (including the $\mathrm{CCW}$ system) is identified as the most important system with respect to pipe failure. The high importance is because loss of this system results in failure of the safety and 
Table 4.4. Dominant Accident Sequences at Zlon-1

\begin{tabular}{|c|c|c|}
\hline Sequence & Description & $\begin{array}{l}\text { Mean Fre- } \\
\text { quency (per } \\
\text { plant year) }\end{array}$ \\
\hline 1 & CCW Failure, causing failure of all charging and Si pumps, seal LOCA. & $1.2 \mathrm{E}-4$ \\
\hline 2 & Small LOCA, failure of recirculation. & $1.6 \mathrm{E}-5$ \\
\hline 3 & Large LOCA, failure of recirculation cooling. & $4.9 \mathrm{E}-6$ \\
\hline 4 & Medium LOCA, failure of recirculation cooling. & $4.9 \mathrm{E}-6$ \\
\hline 5 & $\begin{array}{l}\text { Loss of off-site power; failure of AFWS; failure of feed and bleed; failure } \\
\text { to restore AC power in } 1 \mathrm{hr} \text { (recovery prior to } 4 \mathrm{hr} \text { ). }\end{array}$ & $2.1 \mathrm{E}-6$ \\
\hline 6 & Large LOCA, failure of low pressure injection. & $1.4 \mathrm{E}-6$ \\
\hline 7 & $\begin{array}{l}\text { Loss of off-site power; failure of AFWS; failure of feed and blecd; failure } \\
\text { to restore AC power in } 4 \mathrm{hr} \text { (recovered by } 8 \mathrm{hr} \text { ). }\end{array}$ & 5.7E-7 \\
\hline 8 & $\begin{array}{l}\text { Loss of off-site power; CCW/SWS Loss, failure to recover AC power in } \\
1 \mathrm{hr} \text { (recovery prior to } 4 \mathrm{hr} \text {.) }\end{array}$ & 3.2E-7 \\
\hline 9 & $\begin{array}{l}\text { Same as Sequence No. 8, only this represents the SWS common mode } \\
\text { portion of the rebaselined Zion-1 Review Sequence No. } 3 \text {. }\end{array}$ & $3.0 \mathrm{E}-7$ \\
\hline 10 & $\begin{array}{l}\text { Loss of off-site power; CCW/SWS Loss; failure to restore AC power in } \\
8 \mathrm{hr} \text {; failure of containment sprays and fan coolers. }\end{array}$ & 2.1E-7 \\
\hline 11 & $\begin{array}{l}\text { Loss of off-site power; CCW/SWS Loss; failure to restore AC power in } \\
4 \mathrm{hr} \text { (recovery prior to } 8 \mathrm{hr} \text {.) }\end{array}$ & $1.5 \mathrm{E}-7$ \\
\hline 12 & $\begin{array}{l}\text { Loss of off-site power, failure of SWS; failure to restore AC power in } 8 \mathrm{hr} \text {. } \\
\text { This sequence represents the SWS portions of the rebaselined Zion-1 } \\
\text { Review Sequence No. } 4 \text { and No. } 6 \text {. }\end{array}$ & $1.5 \mathrm{E}-7$ \\
\hline 13 & $\begin{array}{l}\text { Same as Sequence No. } 12 \text { above, only this is the CCW portion of the } \\
\text { rebaselined Zion-1 Review Sequence No. } 4 \text {. }\end{array}$ & $1.0 \mathrm{E}-7$ \\
\hline 14 & Interfacing Systems LOCA. & $1.0 \mathrm{E}-7$ \\
\hline 15 & $\begin{array}{l}\text { Failure of DC bus } 112 \text {, causing Loss of one PORV and toss of AC } \\
\text { bus 148, failure of Auxiliary Feedwater. }\end{array}$ & $5.0 \mathrm{E}-8$ \\
\hline 16 & $\begin{array}{l}\text { Same as Sequence No. 11, only this represents the SWS common mode } \\
\text { portion of the rebaselined Zion-1 Review Sequence No. } 2 \text {. }\end{array}$ & $4.8 \mathrm{E}-8$ \\
\hline 17 & Loss of off-site power; CCW failure to recover $\mathrm{AC}$ power in $8 \mathrm{hr}$. & 3.7E-8 \\
\hline & Total Core Damage Frequency & $1.5 \mathrm{E}-04$ \\
\hline
\end{tabular}


Table 4.5. Birnbaum Importance Ranking for Zion-1 Systems ${ }^{\left({ }^{(}\right)}$

\begin{tabular}{|c|c|c|}
\hline System & $\mathrm{I}^{\mathrm{B}}$ & Rank \\
\hline RPV & 1.0 & 1 \\
\hline SWS $^{(\mathrm{b})}$ & 1.0 & 2 \\
\hline RCS & $1.2 \mathrm{E}-02$ & 3 \\
\hline LPI & $3.5 \mathrm{E}-03$ & 4 \\
\hline HPI & $1.1 \mathrm{E}-03$ & 5 \\
\hline AFW & $1.2 \mathrm{E}-04$ & 6 \\
\hline PCS $^{(c)}$ & -- & 7 \\
\hline $\mathrm{SG}^{(\mathrm{c})}$ & -- & 8 \\
\hline
\end{tabular}

(a) Only systems of interest to Code-Type-ISI are listed. The ranking for the RPV system was assumed to be one for this analysis.

(b) Listed as SWS for consistency. Loss of SWS would cause a loss of CCW system.

(c) Obtaincd from Surry-1 results.

Table 4.6. Inspection Importance Ranking for Zion-1 Systems

\begin{tabular}{|c|c|c|}
\hline System & $\mathrm{I}^{\mathrm{w}}$ & Rank \\
\hline SWS & $4.7 \mathrm{E}-05$ & 1 \\
\hline RPV & $5.0 \mathrm{E}-06$ & 2 \\
\hline LPI & $1.3 \mathrm{E}-06$ & 3 \\
\hline HPI & $1.1 \mathrm{E}-06$ & 4 \\
\hline RCS & $5.8 \mathrm{E}-07$ & 5 \\
\hline AFW & $5.6 \mathrm{E}-09$ & 6 \\
\hline SG & -- & 7 \\
\hline PCS & -- & 8 \\
\hline
\end{tabular}

high-pressure injection pumps, and failure of the reactor coolant pump (RCP) seals. The result is an RCP seal LOCA with no source of high-pressure inventory makeup. As a note, the $\mathbf{I}^{\mathrm{w}}$ value for the SWS was based on the estimated pipe failure probability from PNL's earlier analysis which was lower than the value calculated from the Zion-1 PRA (e.g., 1.2E-04 for pipe rupture).

The reactor pressure vessel, low-pressure injection, and high-pressure injection systems follow in importance. The importances of these systems are primarily due to their important functions in preventing the uncovering of the reactor corc or providing coolant injection or recirculation following an accident. The reactor coolant, auxiliary feedwater, and the other major support systems have a lower importance compared with the other systems; this is primarily because of their lower pipe failure probabilities or higher in system reliabilities.

Zion-1 has a significantly higher core damage frequency than the other PWRs. This is because Zion-1 is more susceptible to loss of service water and loss of CCW than other plants. As mentioned throughout this section, the reactor coolant pump seal cooling can be provided by two methods (thermal barrier or seal injection flow). However, both methods are dependent on the $\mathrm{CCW}$ system. If a reactor coolant pump scal LOCA occurs before restoration of the $\mathrm{CCW}$, the safety injection pumps (as are the charging pumps) are unable to provide coolant injection because they too are dependent on component cooling water. Based on NRC information, Commonwealth Edison has committed to eliminating this susceptibility by providing an independent and redundant source of cooling for the charging pumps, and modifying the reactor coolant pump seals. When these changes are made, the core damage frequency for Zion-1 will be reduced to at least the level of the other PWRs.

A sensitivity analysis was performed in estimating the changes in $\mathrm{I}^{\mathrm{w}}$ ranking for Zion-1 systems. Similar to the preceding section, the system pipe failure probabilities were assumed to be 1.0 . This is basically the system Birnbaum Importance Measures (Table 4.5). The system that led to largest increase in ranking was the RCS, a rank of 3, an increase of 2 in system ranking. Other systems maintain the same relative rankings. 
The present CCW system failure mode is highly controversial. This is because the Zion-1 PRA analysis used a very conservative pipe rupture probability based on the WASH-1400 pipe rupture analysis for primary system piping (i.e., pipes exposed to high temperatures and pressures), time of recovery, and the more stringent $\mathrm{CCW}$ system success criterion requirements. The $\mathrm{CCW}$ system presents a very different environment for pipe fatigue. The CCW system is not pressurized to the level of the primary system, and the operating temperature is significantly lower. Although low pressure pipes do fail, it is easy to imagine how the low energy pipe rupture probability could be much less than that of pipes exposed to high energy environments; however, how much lower is not known. To provide a perspective of potential impact on this issue, an additional sensitivity analysis was also performed.

A sensitivity analysis was performed to reprioritize the system Inspection Importance at Zion-1. This was done by removing the pipe rupture failure mode from the sequence model. The new total core damage frequency was estimated to be about 3.6E-05/py. The results indicated that except reordering in rankings between the RPV and the SWS systems (e.g., the RPV ranks first, followed by the SWS), the remaining safety system rankings remain unchanged with respect to pipe failure. Small change in SWS ranking is primarily because of the importances of other SWS failure modes.

The following plant-specific insight was obtained from the Zion-1 PRA. It may affect the system ranking results between Zion-1 and other plants:

1. Service Water or Component Cooling Water System Unavailabilities

At Zion, component cooling water is needed for operation of the charging and high-pressure safety injection pumps and loss of CCW (or service water, which would render $\mathrm{CCW}$ inoperative) would result in loss of these high-pressure systems. This translated into a loss of reactor coolant pump scal injection and a loss of the capability to inject high pressure makeup to the primary system. Simultaneously, loss of CCW was assumed to mean a loss of cooling to the reactor coolant pump seal thermal barrier heat exchangers. Thus, the reactor pump shaft seals will lose both forms of cooling. The importance of the loss of CCW scenario is increased further by the fact that the CCW at Zion-1, although it has appropriate redundancy of pumps and valves, nevertheless sends its flow through a common header. As noted above, the modifications planned by the owner will eliminate this accident sequence from consideration.

\subsubsection{Sequoyah Nuclear Power Station Unit 1}

The Sequoyah Nuclear Power Station Unit 1 (Sequoyah-1) is a Westinghouse-designed four-loop PWR rated at $1128 \mathrm{MWe}$ capacity with an ice condenser containment. The balance of plant and the containment building were designed and constructed by the utility. Sequoyah-1 is located near Chattanooga, Tennessee. It is oper ted by the Tennessee Valley Authority, and started commercial operation in 1981.

\subsubsection{Sequoyah-1 Core Damage Frequency}

The mean value of the total core damage frequency for Sequoyah-1 from internally initiated events was estimatcd to be 1.0E-04/py (Bertucio et al. 1986b) with the 95 and 5 percent upper and lower bounds of $3.6 \mathrm{E}-04 / \mathrm{py}$ and $8.3 \mathrm{E}-06 / \mathrm{py}$, respectively. Accidents initiated by LOCA comprise more than half of the total core damage frequency ( 59 percent). Accidents involving loss of CCW or service water comprise an additional 31 percent of the total core damage frequency. Loss of clectrical supplies (on-site and off-site) contributes about 8 percent of the total core-damage frequency, and other accident initiators (c.g., ATWS) comprise about 1 percent of the total core damage frequency.

The LOCA sequences, both inside and outside containment, are the largest contributor to core-damage frequency. The highest LOCA sequence frequency involves a small LOCA, followed by failure of the highpressure recirculation system. Although containment heat removal systems are available, the continued heatup and boiloff of primary coolant results in core damage. Other LOCA sequences involve failures of the low-pressure injection or recirculation system and of the containment spray system.

The loss of CCW is the next important sequence. Loss of $\mathrm{CCW}$ results in the failure of $\mathrm{RCP}$ seals, creating a 
small LOCA. The loss of component cooling also results in the unavailability of the charging system, safety injection system, and the containment spray system due to loss of cooling water to these pumps. The inabili.y to deliver high-pressure makevp to the RCS in response to the RCP seal LOCA results in core damage.

Station blackout sequences as a group are the next largest contributor to the total core damage frequency. Station blackout is defined as a loss of power on the two $6.9 \mathrm{kV}$ AC shutdown boards at Unit 1, which leads to the loss of all AC power (except vital AC power, which is fed through inverters from the $125 \mathrm{~V} \mathrm{DC}$ buses). The most dominant core damage sequence is caused by a reactor coolant pump seal LOCA resulting from station blackout. High-pressure injection and containment sprays are also unavailable with the loss of $A C$ power. Other important station blackout sequences involve failure of the auxiliary feedwater system or failure of the power-operated relief valves to reclose (PORVs). The remaining core damage sequences are ATWS. These sequences involve transients followed by failure to scram the reactor and then failure to provide emergency boration.

Table 4.7 summarizes the contributions to the frequency of core damage from the major sequences for each initiating event. Values shown in this table were based on point-estimate sequence frequencies. Together, these sequences contributed about 99 percent of the total core damage frequency.

\subsubsection{Sequoyah-1 System Importance Analysis}

The Sequoyah-1 PRA contains six initiating event categorics. They ranged from LOCAs of various sizes inside containment building, transients involving degraded electrical power supplies, to loss of component cooling water or service water. These categories of initiating events combine together to make up 97 cut sets. The frequencies of these cut sets together sum to a total core damage frequency of $1.0 \mathrm{E}-04 / \mathrm{py}$ at Sequoyah-1.

The risk increase, the risk reduction, the Birnbaum Importance, and the Inspection Importance Measures for systems at Sequoyah-1 were calculated using the method described in the preceding section. The results of the calculation indicate that systems that have the greatest risk increase with regard to core damage frequency are the reactor pressure vessel, low-pressure injection, CCW, high-pressure injection, and the reactor coolant systems. The systems found to cause the greatest reduction in core damage frequency if their probabilities are significantly reduced are the reactor coolant, high-pressure injection, service water, and the low-pressure injection systems. The results of the system Birnbaum Importance ranking for the Sequoyah-1 plant are presented in Table 4.8 .

Using the above system Birnbaum Measure results and the PWR system pipe failure probabilities presented in Table 2.1 (Section 2.3 of Chapter 2.0), the $\mathrm{I}^{\mathrm{w}}$ for systems were then calculated. The $I^{\mathrm{w}}$ for systems are presented in Table 4.9, ranked in order of decreasing impacts.

The high-pressure and low-pressure injection/recirculation systems are identified as the most important systems with respect to pipe failure. The high importance is due to their important function of providing emergency coolant injection and recirculation following a loss of coolant accident and their relatively high system pipe failure probabilities. Additionally, the high importance is also due to the ice condenser containment design at Sequoyah-1. The ice condenser containment is smaller and has a lower design pressure relative to other PWR containment types. This leads to containment spray actuation in response to small LOCA at lower containment pressure than other PWRs. This, combined with a large spray pump capacity, causes faster depletion of the refucling water storage tank and an earlier switch to the recirculation mode. At Sequoyah-1, this switchover is a complex manual operation that must be done rather quickly and under stressful conditions.

The RPV and the SWS are identified as the next important systems. The importance of the RPV system is primarily due to its important function in preventing the reactor core from becoming uncovered following an accident. For the SWS system, loss of the SWS system could lead to core damage because of the dependency of the reactor coolant pump seal cooling, the charging system, and the safety injection system on this system. The reactor coolant, auxiliary feedwater, steam generator, and the power conversion systems follow in importance, primarily because of their lower pipe failure probabilities or system unavailabilities. 
Table 4.7. Dominant Accident Sequences at Sequoyah-1

Sequence

$\mathrm{S}_{2} \mathrm{H}_{2}$

$\mathrm{T}_{\mathrm{CCW}}$

$\mathrm{S}_{2} \mathrm{H}_{3}$

$\mathrm{S}_{2} \mathrm{H}_{3} \mathrm{~F}$

$\mathrm{T}_{1} \mathrm{D}_{3} \mathrm{WD}_{1} \mathrm{~F}$

$\mathrm{S}_{1} \mathrm{H}_{2}$

$T_{\text {DCII }} L_{1} P_{1}$

$\mathrm{T}_{\mathrm{DCl}} \mathrm{L}_{1} \mathrm{P}_{1}$

$T_{1} L_{1} D_{1} F$

$\mathrm{S}_{1} \mathrm{H}_{4}$

TKRZ

$\mathrm{T}_{2} \mathrm{~L}_{1} \mathrm{MP} \mathrm{P}_{1}$

$\mathrm{TKRD}_{4}$

$\mathrm{AD}_{5}$

$\mathrm{S}_{1} \mathrm{H}_{4} \mathrm{~F}$

$\mathrm{S}_{1} \mathrm{~F}$

$\mathrm{V}$

$T_{1} Q_{1} D_{1} F$
Description

Small LOCA with failure of high pressure recirculation.

Loss of all component cooling water (CCW) resulting in a seal LOCA followed by failure of high pressure injection and failure of containment sprays as a result of the $\mathrm{CCW}$ failure.

Small LOCA with failure of the LPR system to provide flow to the high pressure recirculation system.

Small LOCA with failure of the LPI system in the LPI miniflow mode or the LPR system and failure of containment spray recirculation.

Loss of off-site power with failure of seal injection flow and all sequence cooling water resulting in seal LOCA, high pressure injection failure, and containment spray failure.

Intermediate LOCA with failure of high pressure recirculation. to achieve successful opening of PORVs and block valves to feed and bleed.

Loss of 125 VDC bus I followed by failure of AFW and failure to achieve successful opening of PORVs and block valves to feed and bleed.

Loss of off-site power with failure of auxiliary feedwater, failure of high pressure injection, and failure of containment spray.

Intermediate LOCA with failure of the LPI system in the miniflow mode, or low pressure recirculation.

Transient followed by failure to scram, failure of manual scram, and unfavorable for temperature coefficient which results in RCS overpressure.

Transient with initial loss of PCS and main feedwater, failure of auxiliary fecdwater, failure to recover main feedwater, and failure to achieve successful opening of PORVs for feed and bleed.

Transient followed by failure to scram, failure of manual scram, and failure of emergency boration.

Large LOCA with failure of cold leg accumulators.

Intermediate LOCA with failure of the LPI system in the miniflow mode, or low pressure recirculation and failure of containment spray.

Intermediate LOCA with failure of containment sprays resulting in containment heat removal failure.

Interfacing LOCA.

Loss of off-site power followed by failure of a PORV to reclose, failure of high pressure injection, and failure of containment spray.
$1.6 \mathrm{E}-6$

$1.1 \mathrm{E}-6$

Mean Frequency (per plant year)

2.9E-5

2.7E-5

9.7E-6

7.7E-6

$2.9 \mathrm{E}-6$

$1.1 \mathrm{E}-6$

8.3E-7

7.9E-7

$6.8 \mathrm{E}-7$

$5.2 \mathrm{E}-7$

4.1E-7

$3.8 \mathrm{E}-7$

$3.8 \mathrm{E}-7$

3.3E-7 
Table 4.7. (continued)

\begin{tabular}{|c|c|c|}
\hline Sequence & Description & $\begin{array}{l}\text { Mean Fre- } \\
\text { quency (per } \\
\text { plant year) }\end{array}$ \\
\hline $\mathrm{AH}_{1}$ & Large LOCA with failure of low pressure recirculation. & $2.0 \mathrm{E}-7$ \\
\hline AF & $\begin{array}{l}\text { Large LOCA with failure of containment sprays resulting in failure of } \\
\text { containment heat removal. }\end{array}$ & $1.9 \mathrm{E}-7$ \\
\hline $\mathrm{AH}_{1} \mathrm{~F}$ & $\begin{array}{l}\text { Large LOCA, with failure of low pressure recirculation and containment heat } \\
\text { removal. }\end{array}$ & $1.9 \mathrm{E}-7$ \\
\hline $\mathrm{AD}_{6}$ & Large LOCA with failure of low pressure injection. & $1.6 \mathrm{E}-7$ \\
\hline
\end{tabular}

Total Core Damage Frequency

1.0E-04

A sensitivity analysis was performed to calculate the system Inspection Importance at Sequoyah-1. This was performed by letting pipe failure probabilities of all systems of interest approach 1.0, this led to the result presented in Table 4.8, which is the same as the Birnbaum system importances.

The following important plant-specific design insights were obtained from the Sequoyah-1 PRA. They may affect the comparability of results between Sequoyah-1 and other plants with respect to Weld Inspection Importance.

\section{Containment Design}

The design features of Sequoyah's ice condenser containment lead to containment spray actuation at a lower pressure setpoint than at a corresponding large dry containment design, resulting in containment spray actuation over a larger break-size spectrum. This, combined with a large spray pump capacity, causes all small LOCA sequences to require containment sump water recirculation for emergency core cooling system operation. The process of switching emergency core cooling system and containment sprays from injection mode to the recirculation mode at Sequoyah involves a series of operator actions, must be accomplished in a short time period, and is only partially automatic.
Table 4.8. Birnbaum Importance Ranking for Sequoyah-1 ${ }^{(a)}$

\begin{tabular}{|c|c|c|}
\hline System & $\mathrm{I}^{\mathrm{B}}$ & Rank \\
\hline RPV & 1.0 & 1 \\
\hline LPI & $4.9 \mathrm{E}-02$ & 2 \\
\hline SWS $^{(\mathbf{b})}$ & $3.6 \mathrm{E}-02$ & 3 \\
\hline HPI & $2.2 \mathrm{E}-02$ & 4 \\
\hline RCS & $4.4 \mathrm{E}-02$ & 5 \\
\hline AFW & $6.4 \mathrm{E}-04$ & 6 \\
\hline PCS & $3.4 \mathrm{E}-08$ & 7 \\
\hline SG & $3.4 \mathrm{E}-08$ & 8 \\
\hline
\end{tabular}

(a) Only systems of interest to Code-Type-ISI are listed. The ranking for the RPV system was assumed to be one for this analysis.

(b) SWS failure as a contribution to $\mathrm{CCW}$ failure.

2. Susceptibility to Component Cooling Water Faults

Sequoyah-1 is particularly susceptible to faults in the CCW system (or SWS) because of its role in reactor coolant pump seal cooling and component cooling. Reactor coolant pump seal cooling can be provided by two methods (i.e., CCW to the thermal barrier or seal injection flow from the charging pumps). Both methods are dependent 
Table 4.9. Inspection Importance Ranking for Sequoyah-1

\begin{tabular}{|c|c|c|}
\hline System & $I^{\mathrm{w}}$ & Rank \\
\hline HPI & $2.1 \mathrm{E}-05$ & 1 \\
\hline LPI & $1.9 \mathrm{E}-05$ & 2 \\
\hline RPV & $5.0 \mathrm{E}-06$ & 3 \\
\hline SWS & $1.7 \mathrm{E}-06$ & 4 \\
\hline RCS & $2.1 \mathrm{E}-07$ & 5 \\
\hline AFW & $3.0 \mathrm{E}-08$ & 6 \\
\hline SG & $3.4 \mathrm{E}-10$ & 7 \\
\hline PCS & $1.3 \mathrm{E}-11$ & 8 \\
\hline
\end{tabular}

on the $\mathrm{CCW}$, which is also required for the operability of the safety injection system that would be expected to respond to a seal LOCA.

\subsubsection{Crystal River Nuclear Power Plant Unit 3}

The Crystal River Nuclear Power Plant Unit 3 (Crystal River-3) is a Babcock and Wilcox-designed PWR rated at $821 \mathrm{MWe}$ capacity with a large, dry containment. The balance of plant was designed and constructed by the Gilbert Architect-Engineer Company. It is located near Red Level, Florida. Crystal River-3 is operated by the Florida Power Corporation, and started commercial operation in 1977.

\subsubsection{Crystal River-3 Core Damage Frequency}

The mean value of the total core damage frequency for Crystal River-3 from internally initiated events was estimated to be 5.7E-05/py (Florida Power Corporation 1987). Accidents initiated by loss of station blackout comprise 51 percent of the total core damage frequency. Accidents involving loss of service water comprise additional 30 percent of the total core damage frequency. Small LOCA contributes about 3 percent of the total core damage frequency, and other transient or accident initiators (e.g., loss of main feedwater, steam generator tube rupture, etc.) comprise the remaining 16 percent of the total core damage frequency.

The station blackout sequences (initiated by a loss of off-site power, and followed by failure of both diesel generators) are the largest contributor to the total core damage frequency. The most dominant corc damage sequences are caused by a loss of steam generator cooling (by the loss of MFW system and loss of EFW motor-driven pump) and ultimately HPI cooling resulting from station blackout. The turbine-driven EFW pump can maintain RCS heat removal with the station batteries providing vital instrumentation and control power until $\mathrm{AC}$ power is restored. However, the time available for restoration of the power is limited by the capacity of the batteries. Core uncovering due to reactor coolant system inventory boiloff will occur $50 \mathrm{~min}$ utes after total loss of decay heat removal unless AC power is recovered. Other core damage sequences resulted from degraded electrical power supplies. The dominant sequences in this group involve loss of a $4160 \mathrm{~V}$ ES bus, followed by unavailabilities of the makeup pumps by either a maintenance outage, hardware failure, or failure of the suction source to the makeup pump.

The loss of service water is the next important sequence. Because of the plant-specific nature of the SWS, loss of service water results in the loss of cooling to the makeup pumps, which have no alternative cooling source. If flow is not restored within 12 hours, primary inventory will decrease to the point where adequate core cooling can no longer be maintained, and core uncovering begins.

The highest LOCA sequence frequency involves a small LOCA, followed by failure of high-pressure recirculation cooling. During the recirculation cooling mode, water is drawn from the containment sump by the low-pressure decay heat removal (DH) pumps. The DH pumps then supply the high-pressure makeup pumps, which recirculate water to the RCS. A major failure of the high-pressure recirculation cooling system involve failures in the low pressure (DH) portion of the flow path. The continued system heatup and boiloff of primary coolant results in core damage. Other LOCA sequences involve failures of the low-pressure recirculation system following a large LOCA. Failure of low- 
pressure recirculation is caused by containment sump failure or failure of both decay heat pumps.

The remaining core damage sequences are initiated by steam generator tube rupture, loss of main feedwater, and transients requiring primary pressure relief. The most important sequence is initiated by the steam generator tube rupture, followed by a failure of long term decay heat removal and the operator failing to refill the borated water storage tank.

$\mathrm{Tabl}: 4.10$ summarizes the contributions to the frequency of core damage from the major sequences for each initiating event. Values shown in this table were based on point-estimated sequence frequencies.

\subsubsection{Crystal River-3 System Importance Analysis}

The Crystal River-3 PRA is highly modularized. It contains 10 initiating event categories. They ranged from LOCAs of various sizes, transients involving degraded electrical power supplies, loss of off-site power to loss of service water. These categories of initiating events all together make up 87 cut sets. The frequencies of these cut sets sum to a total core damage frequency of 5.7E-05/py.

Using the internal core damage sequences from the Crystal River-3 PRA, the risk increase, the risk reduction, the Birnbaum Importance, and the Inspection Importance Measures for systems at Crystal River-3 were calculated. The result of the calculations indicate that systems that have the greatest risk increase with regard to core damage frequency are the reactor pressure vessel, low-pressure injection, high-pressure injection, and the service water systems. The systems found to cause the greatest reduction in core damage frequency if their probabilities are significantly reduced are the high-pressure injection and the SWS. The results of the system Birnbaum Importance ranking for the Crystal River-3 plant are presented in Table 4.11 .

Using the above system Birnbaum Measure results and the PWR system pipe failure probabilities presented in Table 2.1 (Section 2.3 of Chapter 2), the I ${ }^{W}$ for systems were then calculated. The $:^{\mathrm{W}}$ for systems are presented in Table 4.12, ranked in order of decreasing impacts.
The low-pressure and high-pressure injection/recirculation systems are identified as the most important systems with respect to pipe failure. The high importance is due to their important function of providing emergency coolant injection and recirculation following an accident and their relatively high system pipe failure probabilities.

The RPV and the SG are identified as the next most important systems. The importance of the RPV system is primarily due to its important function in preventing the reactor core from becoming uncovered following an accident. For the SG system, the importance is due to its high tube rupture probability. The service water, auxiliary feedwater, reactor coolant, and the power conversion systems follow in importance, primarily because of their lower pipe failure probabilities.

A sensitivity analysis was performed to reprioritize the system Inspection Importance at Crystal River-3. This was performed by letting pipe failure probabilities of all systems of interest approach 1.0. This led to a result identical to Table 4.11 , which is the same as the system Birnbaum Importances.

The following important plant-specific design or PRA insights for Crystal River-3 plant were identified. They may affect the comparability of results between Crystal River-3 and other plants with respect to Weld Inspection Importance.

\section{Loss of Makeup Sequences}

The Crystal River-3 high-pressure injection system is also known as the makeup and purification system. This system normally operates in the makeup mode, supplying makeup flow to the primary coolant system and seal injection flow to the RCPs. Loss of makcup was assumed to result in failure of all cooling and injection to the RCP seals, and a primary system leak sufficiently large to result in loss of inventory necessary to remove decay heat. However, based on plant information, a loss of makcup requires approximately 12 hours to reduce the RCS inventory to the point where core uncovering begins. Experimental information indicates that the RCP seals will likely remain intact in this situation. In addition, in the Crystal River-3 PRA no credit is taken for restoring components from maintenance or repairing failed 
Table 4.10. Dominant Accident Sequences at Crystal River-3

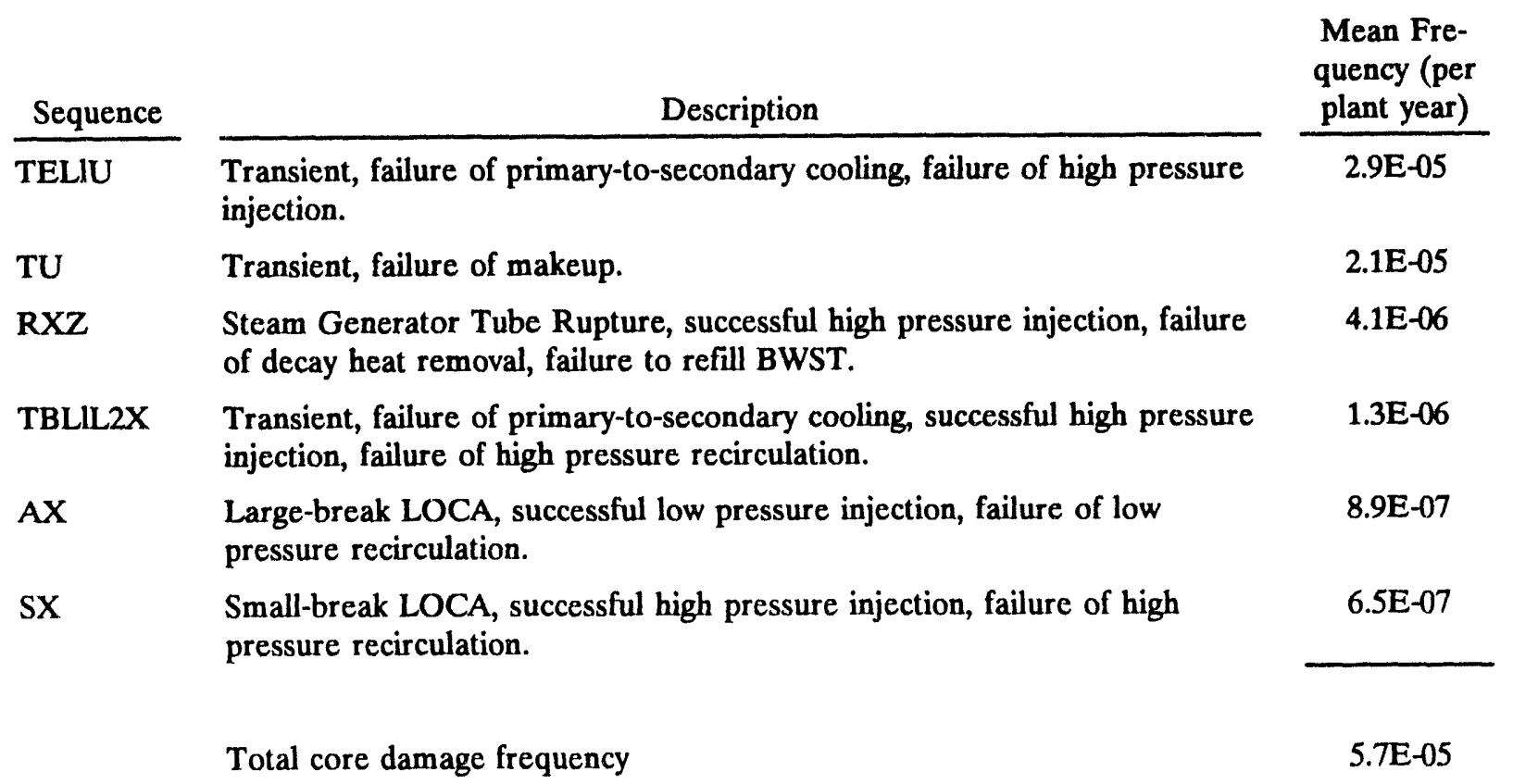

during the 12 hours. This potential conservatism constitutes a large portion of the core damage frequency due to loss of makeup sequences.

\section{Loss of Service Water System}

The SWS at Crystal River-3 includes the nuclear services closed cycle cooling system (service water), the decay heat closed cycle cooling system, and the nuclear services and decay heat sea water (raw water) systems. These systems together provide primary cooling to several of the plant's essential heat removal components. The most important effect of loss of service water relates to the unavailability of the motor-driven EFW pump, which affects the ability to achieve or maintain a stable cooling mode. In addition, loss of service water results in the loss of cooling to the makeup pumps, which have no alternative cooling source.

3. Steam Generator Tube Rupture Events

The steam generator tube rupture (SGTR) event chosen for the Crystal River-3 PRA study was the complete severance of a single tube, resulting in a leakage rate of about $400 \mathrm{gpm}$ at normal RCS and secondary-system conditions. With a conservative SGTR frequency and sequence unavailability estimates, this significantly increases the importance of the SGTR sequences.

\subsubsection{Calvert Cliffs Nuclear Power Plant Unit 1}

The Calvert Cliffs Nuclear Power Plant Unit 1 (Calvert Cliffs-1) is a Combustion Engineering-designed PWR rated at $825 \mathrm{MWe}$ capacity with a large, dry containment. The balance of plant was designed and constructed by Bechtel Corporation. It is located near Lusby, Maryland. Calvert Cliffs- 1 is operated by the Baltimore Gas \& Electric Company, and started commercial operation in 1975.

\subsubsection{Calvert Cliffs-1 Core Damage Frequency}

The mean value of the total core damage frequency for Calvert Cliffs-1 from internally initiated events was estimated to be 1.3E-04/py and consisted almost entirely of sequences with frequencies greater than 1.0E-06/py (Payne 1984). The most significant 
Table 4.11. Birnbaum Importance Ranking for Crystal River-3(a)

\begin{tabular}{|c|c|c|}
\hline System & $\mathrm{I}^{\mathrm{B}}$ & Rank \\
\hline RPV & 1.0 & 1 \\
\hline LPI & $8.4 \mathrm{E}-02$ & 2 \\
\hline SWS $^{(\mathrm{b})}$ & $2.1 \mathrm{E}-02$ & 3 \\
\hline HPI & $1.3 \mathrm{E}-02$ & 4 \\
\hline RCS & $3.1 \mathrm{E}-03$ & 5 \\
\hline AFW & $3.0 \mathrm{E}-03$ & 6 \\
\hline SG & $4.8 \mathrm{E}-04$ & 7 \\
\hline PCS & $1.3 \mathrm{E}-06$ & 8 \\
\hline
\end{tabular}

(a) Only systems of interest to Code-Type-ISI are listed. The ranking for the RPV system was assumed to be one for this analysis.

(b) Including contribution of $\mathrm{CCW}$ failure.

Table 4.12. Inspection Importance Ranking for Crystal River-3

\begin{tabular}{|c|c|c|}
\hline System & $1^{\mathrm{w}}$ & Rank \\
\hline LPI & $3.2 \mathrm{E}-05$ & 1 \\
\hline HPI & $1.2 \mathrm{E}-05$ & 2 \\
\hline RPV & $5.0 \mathrm{E}-06$ & 3 \\
\hline SG & $4.8 \mathrm{E}-06$ & 4 \\
\hline SWS & $9.9 \mathrm{E}-07$ & 5 \\
\hline AFW & $1.4 \mathrm{E}-07$ & 6 \\
\hline RCS & $1.4 \mathrm{E}-07$ & 7 \\
\hline PCS & $4.9 \mathrm{E}-10$ & 8 \\
\hline
\end{tabular}

sequences contributing to the total core damage frequency are anticipated transients without scram (ATWS), 33 percent of the total core damage frequency; accidents involving small-small LOCA comprise additional 20 percent of the total core damage frequency; loss of a DC bus and loss of off-site power contribute 28 percent of the total core damage frequency; and other transient or accident initiators (e.g., transients requiring primary pressure relief, loss of power conversion, etc.) comprise the remaining 19 percent of the total core damage frequency.

The highest sequence frequency involves an ATWS followed by reduced secondary heat removal capacity (i.e., power conversion and/or auxiliary feedwater in a runback mode). The resulting imbalance between energy production and removal rates leads to the heatup of the primary system and an increase in system pressure. Primary system pressure boundary failure is expected to occur. Such pressure can result in system damage severe enough to make continued core cooling highly questionable.

A small LOCA (break size from 1.9 to 3 inches in diameter), followed by failure of high-pressure injection or recirculation (HPI/R) cooling is the next most important sequence. The dominant contributors to this sequence are failures of HPI/R pumps or failures of service water system resulting in loss of HPI/R pump seal cooling. Due to lack of primary makeup, the corc then uncovers and core melt occurs. No other LOCA sequences contribute significantly to the total core damage.

A failure of the DC bus (results in a trip of both units) followed by failures of the PCS and AFW systems contributes significantly to the core damage frequency. As a result of the lack of secondary heat removal, the core inventory boils off through the intermittent cycling of the PORVs. The dominant contributors to this sequence are failures in the operating AFW turbinedriven pump train combined with failure of the operator to start the other (locked-out) turbine-driven pump.

A loss of off-site power, followed by transient-induced LOCA or failure of AFW also results in core damage. The most dominant core damage sequences are caused by 1) a loss of HPI system resulting from a loss of both AC trains, or 2) a loss of AFW motor-driven pump duc to failure of on-site $A C$ power combined with failure of the AFW turbine-driven pump and operator to restore the off-site power. Duc to lack of secondary heat tcmoval, the primary system coolant heats up and boils, and core melt eventually occurs. 
The remaining core damage sequences are initiated by transients that require primary pressure relief, loss of the power conversion system, etc. The most important sequence in this group is initiated by a loss of PCS, followed by a loss of AFW. The dominant contributors to this sequence are failure of the common suction line valve resulting in failure of all operating AFW pumps combined with failure of the operator to realign the AFW suction to an alternative supply and start the locked-out turbine-driven pump.

Table 4.13 summarizes the contributions to the frequency of core damage from the major sequences for each initiating event. Values shown in this table were based on point-estimated sequence frequencies.

\subsubsection{Calvert Clifis-1 System Importance Analysis}

The Calvert Cliffs-1 PRA contains six major initiating event categories. They ranged from small LOCAs, transients involving degraded electrical power supplies, loss of off-site power, transients requiring primary relief to loss of power conversion system. These categories of initiating events together make up to 385 cut sets. The frequencies of these cut sets together sum to a total core damage frequency of $1.3 \mathrm{E}-04 / \mathrm{py}$.

Using the internal core damage sequences from Calvert Cliffs-1 PRA, the risk increase, the risk reduction, the Birnbaum Importance, and the Inspection Importance Measures for systems at Calvert Cliffs-1 were calculated. The result of the calculations indicate that systems that have the greatest risk increase with regard to core damage frequency are the reactor pressure vessel, auxiliary feedwater, high-pressure injection, and the service water systems. The systems found to cause the greatest reduction in core damage frequency if their probabilities are significantly reduced are the service water and the auxiliary feedwater systems.

The results of the system Birnbaum Importance ranking for the Calvert Cliffs-1 plant are presented in Table 4.14. As a note, due to differences in design and operation at Calvert Cliffs-1, the LPI system is considered only as a possible recovery action and therefore, it is not prioritized. More discussions of this system are provided later in this section.

Using the above system Birnbaum Measure results and the PWR system pipe failure probabilities presented in
Table 2.1 (Section 2.3 of Chapter 2.0 ), the $I^{\mathrm{W}}$ for systems were then calculated. The $I^{W}$ for systems are presented in Table 4.15, ranked in order of decreasing impacts.

The high-pressure injection (or recirculation) and the auxiliary feedwater systems are identified as the most important systems with respect to pipe failure. The high importance is due to the relatively frequent demands for these systems compared to demand for other systems, and the relatively high failure probabilities associated with the other terms involved in sequences with these systems. From Table 4.15, it is essential to note that the LPI does not appear in the list of risk importance systems. The specific reasons for this are outlined below:

1. The primary function of the LPI system is to provide the borated water to the RCS to cool the core following LOCAs (particularly for large LOCA). Since large LOCA is not a dominant accident initiator at Calvert Cliffs-1, the system that is designed to mitigate LOCA should not be a high-risk-important system.

2. Because of plant design and procedures, the LPI system is not normally used in the recirculation mode. At Calvert Cliffs-1, the HPI is a preferred system for plant normal operation, transients and accidents, the LPI can be used but, depending on the way in which the recirculation signal was generated, some complicated operator actions might be involved. In the Calvert Cliffs-1 PRA, the LPI system was considered as a possible recovery action, and thus no specific failure related to LPI system was modeled.

The RPV and the SWS are identified as the next important systems. The importance of the RPV system is primarily due to its important function in preventing the reactor core from uncovering following an accident. The high importance of the SWS system is primarily due to its important function in removing heat from various plant essential components. The steam generator, reactor coolant, and the power conversion systems follow in importance, primarily because of their higher system reliabilities compared to the other systems. 
Table 4.13. Dominant Accident Sequences at Calvert Cliffs-1

Sequence

ATWS

TDCL

$\mathrm{S}_{2} \mathrm{H}$

$\mathrm{S}_{2} \mathrm{FH}$

$\mathrm{T}_{2} \mathrm{~L}$

$\mathrm{T}_{4} \mathrm{KU}$

$\mathrm{T}_{4} \mathrm{ML}$

$\mathrm{T}_{1} \mathrm{Q}-\mathrm{D}^{\prime \prime} \mathrm{CC}^{\prime}$

$\mathrm{T}_{1} \mathrm{~L}$

$-$

$\mathrm{T}_{4} \mathrm{KQ}$

$\mathrm{T}_{3} \mathrm{KQ} / \mathrm{U}$

$\mathrm{T}_{3} \mathrm{ML}$

$\mathrm{S}_{2} \mathrm{D}^{\prime \prime}$

$\mathrm{T}_{1} \mathrm{LCC}$

TB

TBVW

TBUl

TBUIVW

TBU

TBUV
Description

Anticipated transient without scram.

Loss of 125 VDC bus 11 followed by failure of AFW system.

Small-small LOCA followed by failure of high-pressure safety recirculation system

Small-small LOCA followed by high pressure safety injection system and containment spray (recirculation) system.

Initiating by loss PCS followed by failure of AFW system.

Transient initiator followed by failure of the RPS and CVCS system.

Transient initiator followed by failure of the PCS system and the AFW system.

Loss of off-site power followed by relief valves fails to release, and failures of HPI and containment spray (injection) and air cooling systems.

Loss of off-site power followed by failure of the AFW system.

Station blackout sequences.

Transient initiator followed by failure of the RPS and primary relief valves systems.

Transient (requiring primary relief) initiator followed by failure of the RPS and cues (or relief valves fail to reclose).

Transient (requiring primary relief) initiator followed by failure of the PCS and AWF systems.

Small-small LOCA initiator followed by failure of the HPI system.

Loss of off-site power initiator followed by failure of the AFW, containment air recirculation and cooling, and containment spray (injection) systems.

Station blackout with HPCS initially available but lost in six to eight hours.

Station blackout with HPCS initially available but lost in six to eight hours. RHR not available with LOSP recovery. No HPCS.

Station blackout with RCIC initially available but lost in six to eight hours. No HPCS RHR not available with LOSP recovery.

Station blackout with the immediate loss of both HPCS and RCIC.

Station blackout with immediate loss of both HPCS and RCIC. RHR not available with LOSP recovery.
$2.0 \mathrm{E}-5$

$1.1 \mathrm{E} .6$

2.4E.6

9.4E-7

Mean Frequency (per plant year)

2.8E-5

2.1E-5

$1.4 \mathrm{E}-5$

1.1E-5

7.1E-6

$6.7 \mathrm{E}-6$

$6.3 \mathrm{E}-6$

5.3E-6

4.9E-6

4.4E-6

$4.3 \mathrm{E}-6$

$6.0 \mathrm{E}-6$

$1.7 \mathrm{E}-6$

$1.6 \mathrm{E}-6$

$1.0 \mathrm{E}-6$

9.5E-8

2.1E-8 
Table 4.13. (continued)

\begin{tabular}{|c|c|c|}
\hline Sequence & Description & $\begin{array}{l}\text { Mean Fre- } \\
\text { quency (per } \\
\text { plant year) }\end{array}$ \\
\hline TBUX & $\begin{array}{l}\text { Station blackout with loss of all three power divisions. RCIC is lost because } \\
\text { of battery failure. }\end{array}$ & $3.8 \mathrm{E}-6$ \\
\hline TBUX & $\begin{array}{l}\text { ATWS with MSIVs closed, both SLC pumps available, and ADS inhibited. } \\
\text { No HPCS. }\end{array}$ & $1.7 \mathrm{E}-7$ \\
\hline TCSX & $\begin{array}{l}\text { ATWS with MSIVs closed, SLC failed, HPCS initially available, HPCS is lost } \\
\text { in } 10 \text { to } 15 \text { minutes. }\end{array}$ & $1.2 \mathrm{E}-8$ \\
\hline TQUX & $\begin{array}{l}\text { Turbine trip transient with PCS initially available. High pressure injection } \\
\text { unavailable, no operator depressurization, no RHR, no venting, and no } \\
\text { SPMU. }\end{array}$ & $2.6 \mathrm{E}-7$ \\
\hline \multirow[t]{2}{*}{ TQUV } & $\begin{array}{l}\text { Turbine trip transient with PCS initially available. High pressure injection } \\
\text { unavailable, depressurization, low pressure injection unavailable, no RHR, } \\
\text { no venting, and no SPMU. }\end{array}$ & $7.9 \mathrm{E}-8$ \\
\hline & Total Core Damage Frequency & $1.3 \mathrm{E}-04$ \\
\hline
\end{tabular}

A sensitivity analysis was also performed to reprioritize the system Inspection Importance at Calvert Cliffs-1. This was performed by letting pipe failure probabilities of all systems of interest approach 1.0. This led to the result identical to those in Table 4.14, which is the same as the Birnbaum system importances.

The following important plant-specific design or PRA insights for Calvert Cliffs-1 plant were identified. They may affect the comparability of results between Calvert Cliffs-1 and other plants with respect to Inspection Importance.

\section{Low-Pressure Injection/Recirculation System}

The LPI system is designed for use to replace the coolant loss during the LOCAs and to remove the residual decay heat from the core. This protects the core from becoming uncovered, and experiencing heat up, and subsequent core melt. The LPI system is operated in two modes: injection and recirculation.

In the injection phase, the LPI system operates in conjunction with the safety injection tanks (SITS) system to keep the core covered and cooled during large LOCAs. The SITs consists of four pressurized tanks that supply additional water during the initial phase of the LOCA when the primary pressure reaches 200 psig. For small LOCAS, the HPI system can perform this function alone. For small-small LOCAs, the HPI system must be used in conjunction with the AFW system. This is because additional heat removal is necessary to decrease the primary system pressure to below the shutoff head of the HPI pumps (e.g., about 1275 psia).

In the recirculation phase, either the HPI or LPI can perform the reactor heat removal functions. However, at Calvert Cliffs-1, the HPI system is the preferred system (for all LOCA sizes). This is because the LPI system is designed to shutoff on switchover to the recirculation phase and requires operator action to restart. Operation of the LPI system in the recirculation mode is treated as a recovery action. Thus, it is excluded from the list of important systems. This significantly increases the importance of the HPI and other systems. 
Table 4.14. Birnbaum Importance Ranking for Calvert Cilfra-1 ${ }^{(a)}$

\begin{tabular}{|c|c|c|}
\hline System & $1^{\mathrm{B}}$ & Rank \\
\hline RPV & 1.0 & 1 \\
\hline AFW & $2.7 \mathrm{E}-01$ & 2 \\
\hline SWS $^{(\mathrm{b})}$ & $6.7 \mathrm{E}-02$ & 3 \\
\hline HPI & $4.8 \mathrm{E}-02$ & 4 \\
\hline RCS & $1.1 \mathrm{E}-03$ & 5 \\
\hline PCS & $4.3 \mathrm{E}-05$ & 6 \\
\hline SG & $4.3 \mathrm{E}-05$ & 7 \\
\hline
\end{tabular}

(a) Only syste ins of interest to Code-Type-ISI are listed. The ranking for the RPV system was assumed to be one for this analysis.

(b) Including contribution of salt water and CCW failure

Table 4.15. Inspection Importance Ranking for Calvert Clifrs-1

\begin{tabular}{|c|c|c|}
\hline System & $I^{\mathrm{w}}$ & Rank \\
\hline HPI & $4.6 \mathrm{E}-0.5$ & 1 \\
\hline AFW & $1.3 \mathrm{E}-05$ & 2 \\
\hline RPV & $5.0 \mathrm{E}-06$ & 3 \\
\hline SWS & $3.1 \mathrm{E}-06$ & 4 \\
\hline SG & $4.3 \mathrm{E}-07$ & 5 \\
\hline RCS & $5.2 \mathrm{E}-08$ & 6 \\
\hline PCS & $1.6 \mathrm{E}-08$ & 7 \\
\hline
\end{tabular}

\subsection{Analyses of Boiling Water Reactors}

This section analyzes the two selected BWRs. Similar to the analyses of PWRs, this includes a brief plant description, a summary of accident sequence results from the PRA, and the system prioritization and selection results.

\subsubsection{Peach Bottom Atomic Power Station Unit 2}

The Peach Bottom Atomic Power Station Unit 2 (Peach Bottom-2) is a General Electric BWR-4 product line with a net electrical capacity of $1051 \mathrm{MWe}$ and a Mark I containment. The balance of plant was designed and constructed by Bechtel Corporation. Peach Bottom-2 is located in southeastern Pennsylvania, and is operated by the Philadelphia Electric Company. Peach Bottom-2 started commercial operation in 1974.

\subsubsection{Peach Bottom-2 Core Damage Frequency}

The mean value of the total core damage frequency for Peach Bottom-2 from internally initiated events was estimated to be $8.2 \mathrm{E}-06 /$ py with the 95 and 5 percent upper and lower bounds from the propagation of parameter value uncertainties being $2.4 \mathrm{E}-05 / \mathrm{py}$ and $1.3 \mathrm{E}-06 /$ py, respectively (Kolaczkowski et al. 1986). Two accident types are the principal contributors to the total core damage frequency at Peach Bottom-2, station blackout and anticipated transients without scram.

These two accident types contribute over 90 percent to the total core damage frequency. All other accident types individually represent less than 1 percent of the total core damage frequency.

Station blackout sequences are the largest contributor. Station blackout is defined as loss of all AC power (except vital AC supplied through the DC inverters). This is caused by loss of off-site power and subsequent failure of the diesel generators. The important equipment failure contributions to most of station blackout sequences include common-cause failure of multiple divisions of DC power sources (batteries), failure to recover off-site power, failure to restore any of the four diesel generators, and the combination of diesel generator hardware failures and unavailability due to maintenance.

The most single dominant sequence involves common cause failure of the station batteries. The battery failure prevents - the starting of the diesel generators while at the same time it prevents operation of the high pressure coolant injection system (HPCI) and the reactor core isolation cooling system (RCIC) and prevents depressurization of the reactor via the automatic depressurization system. With no sources of 
coolant makeup available, core damage will begin in $\mathbf{3 0}$ to $\mathbf{4 0}$ minutes. An additional equipment contribution that is important for station blackout sequences is the failure of the emergency service water (ESW) pumps and ESW booster pumps. This failure is caused by the prior failure of the two diesel generators (e.g., \#2 and \#3). The loss of ESW flow results in the loss of jacket cooling to the other diesel generators (\#1 and \#4) and they subsequently fail. The result is a total loss of AC power for sequences initiated by a loss of off-site power.

ATWS sequences are also significant contributors to core damage frequency. All ATWS sequences involve mechanical failures of the control rod system and closure of the main steam isolation valve either as part of the initiating event or shortly thereafter due to reactor water level imbalance. The ATWS sequences are dominated by two types of accidents. The first type involves successful start of the standby liquid control system (SLC) but failure of the HPCI system. RCIC system is not considered sufficient to maintain water level under these conditions. The second type of ATWS sequence involves failure of the SLC system but successful start of the HPCI system. However, without SLC, HPCI fails in approximately 15 minutes because of the high temperature of the suppression pool. Subsequent failure of the operator to depressurized leads to core damage.

Depressurization by the operator will allow the low-pressure systems to provide coolant makeup. This will provide additional time for the operator to recover the SLC or the control rod drive system. However, if recovery is not imminent, containment pressure will rise, resulting in the unavailability of the low-pressure injection systems. If the containment remains pressurized and does not fail, the pressure rises to the point where the safety relief valves are forced closed as a result of containment backpressure. If containment fails, the sump will saturate, thereby failing the low-pressure coolant injection and low-pressure core spray pumps. Subsequent failure of the operator to align condensate or high-pressure service water systems leads to immediate core damage.

LOCAs with loss of low-pressure coolant injection systems represent 1 percent of the total core damage frequency. Transients with loss of coolant injection make up most of the final 1 percent of core damage frequency. Table 4.16 summarizes the contributions to the frequency of core damage from the major sequences for each initiating event. Values shown in this table were based on point-estimated sequence frequencies.

\subsubsection{Peach Bottom-2 System Importance Andysis}

The Peach Bottom-2 PRA contains five major initiating event categories. They range from LOCAs of various sizes, loss of off-site power, transients involving degraded electrical power supplies, loss of off-site power, transients leading to reactor trip with and without power conversion system, to loss of various $A C$ and DC electrical buses. These categories of initiating events taken together make up 99 cut sets. The frequencies of these cut sets sum to a total core damage frequency of 8.2E-06/py.

Using the internal core damage sequences from Peach Bottom-2 PRA, the risk increase, the risk reduction, the Birnbaum Importance, and the Inspection Importance Measures for systems at Peach Bottom-2 were calculated. The result of the alculations indicate that systems that have the greatest risk increase with regard to core damage frequency are the reactor pressure vessel and the emergency service water systems. The systems found to cause the greatest reduction in core damage frequency, if their probabilities are significantly reduced, are the emergency service water and the high pressure cooling injection systems. The results of the system Birnbaum Importance for the Peach Bottom-2 plant are presented in Table 4.17.

Using the above system Birnbaum Measure results and the BWR system pipe failure probabilities presented in Table 2.2 (Section 2.3 of Chapter 2.0), the $\mathrm{I}^{\mathrm{W}}$ for the systems were then calculated. The 1 for systems are presented in Table 4.18, ranked in order of decreasing impact.

The reactor pressure vessel and the emergency service water are identified as the most important systems. The importance of the RPV system is primarily due to its important function in preventing the reactor core from becoming uncovered following an accident. The high importance of the EWS system is primarily due to its important function in providing heat removal to multiple front-line systems or other key support equipment during an emergency shutdown of the plant. 
Table 4.16. Dominant Accident Sequences at Peach Bottom-2

$\frac{\text { Sequence }}{\text { TBUX }}$

Description

Mean Frequency (per plant year)

Short term station blackout with sufficient coincident DC power failure such that

$4.2 \mathrm{E}-6$ core cooling immediately fails and vessel depressurization is not possible. Nonrecovery of AC power in 30 to 40 minutes.

TB Long-term station blackout with successful core cooling until battery depletion at $6 \mathrm{hr}$. Non-recovery of AC power within $3 \mathrm{hr}$ of battery depletion. Vessel repressurization occurs after battery depletion, because SRVs cannot be held open without DC power.

TCUX ATWS with SLC success but HPCI failure followed by failure of timely (hence, a core damage before containment failure type scenario).

TCSR ATWS with SLC failure and successful high then low pressure core cooling. Inadequate or not containment heat removal causes a containment vulnerable before core damage type scenario with eventual loss of core cooling.

TBUP Short-term station blackout with early core cooling failure (with and without multiple DC train failures) and a stuck-open relief valve which slowly depressurizes the vessel. Non-recovery of AC power in $0.5 \mathrm{hr}$.

TCSX ATWS with SLC failure and failure of depressurization following HPCI to $0.5 \mathrm{hr}$ because of high pool temperature. This leads to a core damage before containment failure scenario.

TBU Short-term station blackout with early core cooling failure (no multiple DC train failures). Nonrecovery of AC power in 30 to 40 minutes. Vessel depressurization is likely.

TBP Long-term station blackout with a stuck-open relief valve and with successful core cooling until battery depletion at $6 \mathrm{hr}$. Non-recovery of AC power within $3 \mathrm{hr}$ of battery depletion. Vessel depressurized because of stuck-open valve.

S1V Intermediate LOCA with HPCI success for $2 \mathrm{hr}$ until vessel depressurizes. Low pressure core cooling fails.

TCSAR ATWS with SLC failure, ADS is not inhibited, and low pressure core cooling is successful. Inadequate or no containment heat removal causes a containment failure before core damage scenario with eventual loss of core cooling.

TUV Transient with early loss of all core cooling, but with vessel depressurized.

4.9E-8

AV Large LOCA with early loss of core cooling.

$3.2 \mathrm{E}-8$

TUX Transient with early loss of high pressure core cooling and failure to depressurized. 
Table 4.17. Birnbaum Importance Ranking for Peach Bottom-2(a)

\begin{tabular}{|c|c|c|}
\hline System & $I^{B}$ & Rank \\
\hline Reactor Pressure Vessel (RPV) & 1.0 & 1 \\
\hline Emergency Service Water (ESW) & $3.1 \mathrm{E}-03$ & 2 \\
\hline Reactor Coolant (RCS) & $2.3 \mathrm{E}-04$ & 3 \\
\hline $\begin{array}{l}\text { High Pressure Coolant Injection } \\
(\mathrm{HPCI})\end{array}$ & $1.6 \mathrm{E}-05$ & 4 \\
\hline Standby Liquid Control (SLC) & $9.3 \mathrm{E}-06$ & 5 \\
\hline $\begin{array}{l}\text { Reactor Corc Isolation Cooling } \\
\text { (RCIC) }\end{array}$ & $3.8 \mathrm{E}-06$ & 6 \\
\hline $\begin{array}{l}\text { Powcr Conversion/Main Steam } \\
\text { (PCS/MSS) }\end{array}$ & $7.6 \mathrm{E}-07$ & 7 \\
\hline $\begin{array}{l}\text { Feedwater/Condensate } \\
\text { (FWS/CDS) }\end{array}$ & $6.7 \mathrm{E}-07$ & 8 \\
\hline
\end{tabular}

(a) Only systems of interest to Code-Type-ISI are listed.

Table 4.18. Inspection Importance Ranking for Peach Bottom-2

\begin{tabular}{|c|c|c|}
\hline System & $I^{\mathrm{w}}$ & Rank \\
\hline RPV & $5.0 \mathrm{E}-06$ & 1 \\
\hline ESW & $1.8 \mathrm{E}-06$ & 2 \\
\hline RCS & $3.8 \mathrm{E}-08$ & 3 \\
\hline HPCI & $1.9 \mathrm{E}-08$ & 4 \\
\hline FWS $/ C D S$ & $1.8 \mathrm{E}-09$ & 5 \\
\hline SLC & $1.2 \mathrm{E}-09$ & 6 \\
\hline RCIC & $4.9 \mathrm{E}-10$ & 7 \\
\hline PCS/MSS & $3.5 \mathrm{E}-10$ & 8 \\
\hline
\end{tabular}

The reactor coolant and the high pressure cooling injection systems follow in importance. The importance of the RCS is primarily due to its important function to maintain the primary system integrity, and the importance of the HPIC is primarily due to its important function of providing coolant makeup to the primary system following an accident. The feedwater and condensate, standby liquid control, reactor core isolation cooling, and the power conversion systems follow in importance primarily due to higher system reliabilities.

The sensitivity analysis was also performed to reprioritize the system Inspection Importance at Peach Bottom-2. This was performed by letting pipe failure probabilities of all systems of interest approach 1.0. This led to the results identical to those located in Table 4.17, which are the same as the Birnbaum system importances.

The following important plant-specific design or PRA insights for the Peach Bottom-2 plant were identified. They may affect the comparability of results between Peach Bottom-2 and other plants with respect to Inspection Importance.

\section{Emergency Service Water System Configuration}

Peach Bottom-2 has four diesel generators, and ESW is required for diesel generator cooling. The success criteria for the ESW system in the emergency heat sink mode assumed that both the ESW pumps (A and B) and one of the two booster pumps are required. The booster pumps have the same power supplies as pumps A and B. Thus, a failure of diesel generator \#2 and diesel generator \#3 fails all ESW and therefore fails the remaining two diesels. Failure of diesel generators $\# 2$ and \#3 is sufficient to cause station blackout if off-site power is lost. However, latest plant-specific information indicated that operation of the ESW booster pump is not required to provide sufficient flow for diesel generat or cooling. This fact may reduce the importance of the ESW system.

\section{Containment Failure As It Affects Core Damage}

Containment failure at Peach Bottom-2 (Mark I BWR) is expected to cause failure of the lowpressure coolant injection systems that pumps from the suppression pool, due to saturation of the pool. Venting reduces containment pressure and thus prevents containment failure. 
Peach Bottom-2 offers multiple, diverse systems capable of providing coolant injection into the reactor vessel. For instance, the HPCI, RCIC, and control rod drive pumps provide high-pressure makeup capability. Low-pressure coolant injection, low-pressure core spray, condensate, and high-pressure service water offer low-pressure makeup capability. The multiplicity and diversity of systems make loss of coolant injection due to failure of front-line systems a small contributor to core damage frequency.

\section{High-Capacity Standby Liquid Control System}

The SLC system provides a tackup method to establish and maintain the reactor subcritical. Peach Bottom-2 was modeled as having an "86 gpm equivalent" SLC system. This is achieved by doubling the enrichment of the boron in the SLC system while maintaining the original flow rate.

This larger capacity changes the ATWS scenario by allowing more time for operator action.

\subsubsection{Grand Gulf Nuclear Power Plant Unit 1}

The Grand Gulf Nuclear Power Plant, Unit 1 (Grand Gulf-1) is a General Electric BWR-6 with a net power production capability of $1250 \mathrm{MWe}$ and a Mark III containment. The balance of plant was designed and constructed by Bechtel Corporation. Grand Gulf-1 is located in Port Gibson, Mississippi, and is opcrated by the Mississippi Power and Light Company. Grand Gulf-1 started commercial operation in 1985.

\subsubsection{Grand Guit-1 Core Bamage Frequency}

The mean value of the total core damage frequency for Grand Gulf-1 from internally initiated events was estimated to be 2.9E-05/py with the 95 and 5 percent upper and lower bounds from the propagation of parameter value uncertainties being I.0E-04/py and 3.7E-06/py, respectively (Drouin et al. 1987). All of the important accident sequences (over 98 percent) for Grand Gulf-1 involve station blackout. All other accident sequences individually represent less than 1 percent of the total core damage frequency, including anticipated-transients without scram sequences. Transients with long-term loss of heat removal and LOCAs are not significant contributors to core damage frequency. The principal contributors and dominant accident sequences are summarized in the following paragraphs.

The dominance of station blackout in the estimated total core damage frequency emphasizes the importance of the AC power source unreliability at Grand Gulf-1. Station blackout is defined as loss of $\mathrm{AC}$ power to Divisions 1 and 2 of the electrical system. AC power to Division 3 dedicated to the high-pressure coolant injection system (referred to as high pressure core spray at Grand Gulf-1) may be available during some station blackout sequences. Station blackout is predominantly caused by a loss of off-site power and subsequent failure of diesel generators $\mathbf{A}$ and $\mathbf{B}$. The important failure contributions to most of station blackout sequences include failure to recover off-site power, failure to restore either diesel generator, and the combination of diesel generator hardware failures and unavailability due to maintenance.

The single most dominant sequence involves failure of diesel generators $\mathrm{A}$ and $\mathrm{B}$, but success of diesel generator $C$, which powers the HPIC system, and success of the RCIC system. However, due to extended unavailability of $\mathrm{AC}$ power leads to heatup of the suppression pool $\left(240^{\circ} \mathrm{F}\right.$ to $280^{\circ} \mathrm{F}$ in 6 to 8 hours). At these pool temperatures, it was assumed that the HPCI will experience seal failure, thus leading to unavailability. The RCIC system will be isolated shortly thereafter upon high turbine exhaust backpressure. If the $\mathrm{AC}$ power is not restored after RCIC isolation, core damage will occur.

Two accident sequence types combined to account for about one-fourth of the total core damage frequency. The first has a similar scenario to the one above, except that the HPCl system fails early either because of diesel generator failure or hardware failure in the HPCI system. The RCIC maintains water inventory in the reactor pressure vessel until it is isolated on high backpressure at approximately 8 hours. If the $A C$ power is not restored shortly after RCIC isolation, core-damage will occur. The other station injection blackout sequence type involves the failure of all injection systems very early in the accident. This is due to failure of station batteries or diesel generators, $\mathrm{HPCI}$, and RCIC systems. 
Table 4.19. Dominant Accident Sequences at Grand Gulf-1

\begin{tabular}{|c|c|c|c|}
\hline Sequence & \multicolumn{2}{|c|}{ Description } & $\begin{array}{l}\text { Mean Fre- } \\
\text { quency (per } \\
\text { plant year) }\end{array}$ \\
\hline $\mathbf{B}$ & \multicolumn{2}{|c|}{ Station blackout with HPCS initially available but lost in 6 to $8 \mathrm{hr}$. } & $2.0 \mathrm{E}-5$ \\
\hline TBVW & \multicolumn{2}{|c|}{$\begin{array}{l}\text { Station blackout with HPCS initially available but lost in } 6 \text { to } 8 \mathrm{hr} \text {. RHR not } \\
\text { available with LOSP recovery. }\end{array}$} & $1.1 \mathrm{E}-6$ \\
\hline TBUl & \multicolumn{2}{|c|}{ Station blackout with RCIC initially available but lost in 6 to $8 \mathrm{hr}$. No HPCS. } & $2.4 E-6$ \\
\hline TBUIVW & \multicolumn{2}{|c|}{$\begin{array}{l}\text { Station blackout with RCIC initially available but lost in } 6 \text { to } 8 \mathrm{hr} \text {. No HPCS. } \\
\text { RHR not available with LOSP recovery. }\end{array}$} & $9.5 \mathrm{E}-8$ \\
\hline TBU & \multicolumn{2}{|c|}{ Station blackout with the immediate loss of both HPCS and RCIC. } & $9.4 \mathrm{E}-7$ \\
\hline TBUVW & \multicolumn{2}{|c|}{$\begin{array}{l}\text { Station blackout with the immediate loss of both HPCS and RCIC. RHR not } \\
\text { available with LOSP recovery. }\end{array}$} & 2.1E-8 \\
\hline TBUX & \multicolumn{2}{|c|}{$\begin{array}{l}\text { Station blackout with a loss of all three power divisions. RCIC is lost because } \\
\text { of battery failure. }\end{array}$} & $3.8 \mathrm{E}-6$ \\
\hline TCUX & \multicolumn{2}{|c|}{$\begin{array}{l}\text { ATWS with MSIVs closed, both SLC pumps available, and ADS inhibited. No } \\
\text { HPCS. }\end{array}$} & 1.7E-7 \\
\hline TCSX & \multicolumn{2}{|c|}{$\begin{array}{l}\text { ATWS with MSIVs closed, SLC failed, HPCS initially available, and ADS } \\
\text { innibited. HPCS is lost in } 10 \text { to } 15 \text { minutes. }\end{array}$} & $1.2 \mathrm{E}-8$ \\
\hline TQUX & \multicolumn{2}{|c|}{$\begin{array}{l}\text { Turbine trip transient with PCS initially available. High pressure injection } \\
\text { unavailable, no operator depressurization, no RHR, no venting, and no SPMU. }\end{array}$} & $2.6 \mathrm{E}-7$ \\
\hline TQUV & \multicolumn{2}{|c|}{$\begin{array}{l}\text { Turbine trip transient with PCS initially available. High pressure injection } \\
\text { unavailable, depressurization, low pressure injection unavailable, no RHR, no } \\
\text { venting, and no SPMU. }\end{array}$} & 7.9E-8 \\
\hline & \multicolumn{2}{|l|}{ Total Core Damage Frequency } & $2.9 \mathrm{E}-05$ \\
\hline \multicolumn{2}{|c|}{$\begin{array}{l}\text { WS sequences account for the remaining } 1 \text { percent } \\
\text { the total core damage frequency. The important } \\
\text { uence is where the SLC system succeeds, but the } \\
\text { IC system fails. RCIC is unable to maintain the } \\
\text { ter level under this condition. Table } 4.19 \text { summariz- } \\
\text { the contributions to the frequency of core damage } \\
\text { m the major sequences for each initiating event. } \\
\text { lues shown in this table were based on point- } \\
\text { timated sequence frequencies }\end{array}$} & \multicolumn{2}{|c|}{$\begin{array}{l}\text { Using the internal core damage sequences from Grand } \\
\text { Gulf-1 PRA, the risk increase, the risk reauction, the } \\
\text { Birnbaum Importance, and the Inspection Importance } \\
\text { Measures for systems were calculated. The result of } \\
\text { the calculations indicate that systems that have the } \\
\text { greatest risk increase with regard to core damage fre- } \\
\text { quency are the reactor pressure vessel and the emer- } \\
\text { gency service water, reactor core isolation cooling, and }\end{array}$} \\
\hline
\end{tabular}


the high-pressure coolant injection systems. The systems which were found to cause the greatest reduction in core damage frequency if their failure probabilities are significantly reduced are the emergency service water and high-pressure coolant injection systems. The results of the system Birnbaum Importance for the Peach Bottom-2 plant are presented in Table 4.20.

Table 4.20. Birnbaum Importance Ranking for Grand Gulf-I ${ }^{(a)}$

\begin{tabular}{|c|c|c|}
\hline Systcm & $\mathrm{I}^{\mathrm{B}}$ & Rank \\
\hline $\mathrm{RPV}$ & 1.0 & 1 \\
\hline $\mathrm{ESW}^{(\mathrm{b})}$ & $3.2 \mathrm{E}-03$ & 2 \\
\hline $\mathrm{HPCl}^{(\mathrm{c})}$ & $1.7 \mathrm{E}-04$ & 3 \\
\hline $\mathrm{RCIC}$ & $1.6 \mathrm{E}-04$ & 4 \\
\hline SLC & $8.6 \mathrm{E}-06$ & 5 \\
\hline $\mathrm{RCS}$ & $5.8 \mathrm{E}-07$ & 6 \\
\hline $\mathrm{PCS} / \mathrm{MSS}$ & $1.6 \mathrm{E}-07$ & 7 \\
\hline FWS $/ \mathrm{CDS}$ & $6.1 \mathrm{E}-08$ & 8 \\
\hline
\end{tabular}

(a) Only systems of interest to Code-Type-ISI are listed.

(b) Referred to as the High-Pressure Core Spray system at Grand Gulf-1.

(c) Referred to as the Standby Service Water system at Grand Gulf-1.

Using the above system Birnbaum Measure results and the BWR system pipe failure probabilities presented in Table 2.2 (Section 2.3 of Chapter 2.0 ), the $\mathrm{I}^{\mathrm{W}}$ for systems were then calculated. The $\mathrm{I}^{\mathrm{W}}$ for systems are presented in Table 4.21, ranked in order of decreasing impact.

Similar to the Peach Bottom-2 results, the reactor pressure vessel and the emergency service water are identificd as the most important systems. The importances of these systems are primarily due to their important functions in preventing the reactor core from uncovering following an accident or providing adequate cooling to important front-line systems or key support equipment during an emergency operation.
Table 4.21. Inspection Importance Ranking for Grand Gulf-I

\begin{tabular}{|c|c|c|}
\hline System & $\mathbf{I}^{\mathrm{w}}$ & Rank \\
\hline RPV & $5.0 \mathrm{E}-06$ & 1 \\
\hline ESW & $1.9 \mathrm{E}-06$ & 2 \\
\hline HPCI & $2.0 \mathrm{E}-07$ & 3 \\
\hline RCIC & $2.0 \mathrm{E}-08$ & 4 \\
\hline SLC & $1.1 \mathrm{E}-09$ & 5 \\
\hline FWS/CDS & $1.5 \mathrm{E}-10$ & 6 \\
\hline RCS & $7.5 \mathrm{E}-11$ & 7 \\
\hline PCS/MSS & $2.1 \mathrm{E}-11$ & 8 \\
\hline
\end{tabular}

The high pressure cooling injection and the reactor core isolation cooling are the next important systems. The relatively high importance of these systems are primarily due to their important function to provide coolant to the reactor vessel during accident and their dependency on suppression pool temperature, particular under station blackout conditions. The HPCI fails because of scal failure caused by high suppression pool temperature. The RCIC fails because of isolation on high turbine exhaust pressure, caused by the increased containment pressure.

The standby liquid control, feedwater and condensate, reactor coolant and the power conversion systems follow in importance primarily due to a higher system reliabilities. An additional comment is needed to explain the low importance of the reactor coolant system. This is primarily due to the fact that the LOCA initiating event is not a dominant contributor at Grand Gulf-1 and Grand Gulf- 1 is a BWR/ 6 design. Thus, Grand Gulf-1 uses a motor-driven HPCI system rather than a steam-driven HPCI system for high pressure addition of coolant to the vessel, which improves the reliability of this system for mitigation of transients and small LOCA events. In addition, Grand Gulf-1 has a third train of low-pressure coolant injection that injects directly into the reactor core volume, and thus has one more train than Peach Bottom-2 for mitigation of large LOCAs. This multiplicity and diversity of systems make tran- 
sients and LOCAs with loss of coolant injection a small contributor.

The sensitivity analysis was also performed to reprioritize the system Inspection Importance at Grand Gulf-1. This was performed by letting pipe failure probabilities of all systems of interest approach 1.0. This led to the result identical to those in Table 4.20, which is the same as the Birnbaum system importances.

The following important plant-specific design or PRA insights for Grand Gulf-1 were identified. They may affect the comparability of results between Grand Gulf- 1 and other plants.

1. High-Pressure Coolant Injection Pump Seal Failure

The HPCI pump seals are assumed to fail when the pressure suppression pool (from which the HPCI would take suction) reaches $240^{\circ} \mathrm{F}$ to $280^{\circ} \mathrm{F}$. Pump seal failure is further assumed to fail the pump. During loss of $\mathrm{AC}$ power sequences, the HPCI failure results in loss of coolant injection even if the HPCI dedicated diesel generator operates. The unavailability of the HPCI system due to loss of integrity of high-pressure core spray seals under high suppression pool temperature is an area of uncertainty. This is because of insufficient information regarding the temperature at which the seals would fail and whether seal failure would result in pump failure. At Grand Gulf-1, venting of the suppression pool or improving the reliability of long-term decay heat removal function does not apply, as its containment design in such that the suppression pool will not discharge into the building containing the safety systems.

\section{Containment As It Affects Core Damage}

Containment failure at Grand Gulf -1 is not expected to cause failure of the coolant injection systems that pump from the suppression pool. The low-pressure systems are capable of pumping saturated water, and containment failure is not expected to damage the coolant injection systems. However, at Grand Gulf-1 the RCIC system will be isolated in a long-term station blackout on high exhaust pressure because of the rising containment backpressure. Alternative system designs or provisions to vent containment could improve the availability of this system under station blackout conditions. However, its effectiveness would be limited by depletion of the batteries. 


\subsection{Summary of the Results}

This chapter summarizes the results of PNL's analysis of pressure boundary systems and risk-based inspection priorities for the selected PWR and BWR systems.

\subsection{Summary of Inspection Impor- tance Results for PWR Systems}

Figure 5.1 presents the results of Inspection Importance for various systems for the six PWRs (including Oconee-3 from the earlier PNL study) selected for study. In this figure, the system having a lowest rank (e.g., one) represents the most important system that needs to be inspected. Based on core-damage frequency, it appears that most safety systems, in general, have approximately the same rank for the plants analyzed. The results also indicate that the front-line or the key support systems are quite important.

The low-pressure injection, the high-pressure injection, and the reactor pressure vessel systems are identified as the most important systems with respect to pipe failure. The importance of the low-pressure and the high-pressure injection systems are primarily due to their functions in providing emergency coolant injection and recirculation to the reactor pressure vessel following a transient or accident. The high importance of the reactor pressure vessel is primarily due to its function of preventing the reactor core from becoming uncovered following an accident.

As a note in Figure 5.1, the low-pressure injection system at Calvert Cliffs-1 is not shown as a risk-important system, because a large LOCA was not found to be a significant event at Calvert Cliffs-1. At Calvert Cliffs1 , because of differences in system design and operating procedures the low-pressure injection system is automatically shut down in the recirculation phase of a LOCA. This is because of the high-pressure injection system is designed to draw directly from the containment sump in the recirculation mode and is a preferred system (for all LOCA sizes). The low-pressure injection system can be used, but depending on the way in which the recirculation signal was generated, some complex operator actions might be involved. Operation of the low-pressure injection system in the recirculation mode is treated as a recovery action.

Examination of Figure 5.1 reveals that the service water, auxiliary feedwater, and the steam generator systems are also important. Among the PWRs selected for study, the service water systems at Zion-1 and Sequoyah rank the highest. The reason for this is that these plants have an apparent susceptibility to loss of service water and loss of component cooling water (CCW) that does not appear as dominant contributors in the other PWRs. At these plants, the CCW is needed for operation of the charging and high-pressure safety injection pumps. Loss of CCW (or loss of service water, which would render the CCW system inoperative) would result in loss of these high-pressure systems. Thus, loss of the component cooling of service water systems could cause a small LOCA and disable the systems needed to mitigate a small LOCA. For these plants, the high risk-importance of this system impacts the importance of other systems.

The importance of the auxiliary feedwater system is primarily due to its important function in providing feedwater to the steam generators to provide heat removal from the primary system following an undesired event. In addition, for a station blackout event, the auxiliary feedwater system is the only means of removing decay heat from the reactor core to prevent core damage. As indicated in Figure 5.1, the auxiliary feedwater systems at Calvert Cliffs- 1 and Surry-1 are higher in importance rankings than at the other PWRs. This is primarily due to the relatively frequent demand for these systems as compared with demand for other systems at these plants.

The steam generator system is also identified as an important system. The thin-walled steam generator tubing is an important part of a major barrier against fission product release to the environment. The steam generator tubing also acts as a barrier against steam release to containment in the event of LOCA. In general, this system has relatively the same importance ranking for all plants analyzed. As a note on Figure 5.1, at Oconee-3 and Crystal River-3 the slightly higher in importance ranking for this system is due to a high estimate of steam generator tube rupture (SGTR) frequency, and/or high failure probabilities associated with the other sequences involved with mitigating SGTR.

The reactor coolant and the power conversion are the least risk importance systems. These systems have about the same importance ranking for all the plants analyzed. However, examination of Figure 5.1 reveals 


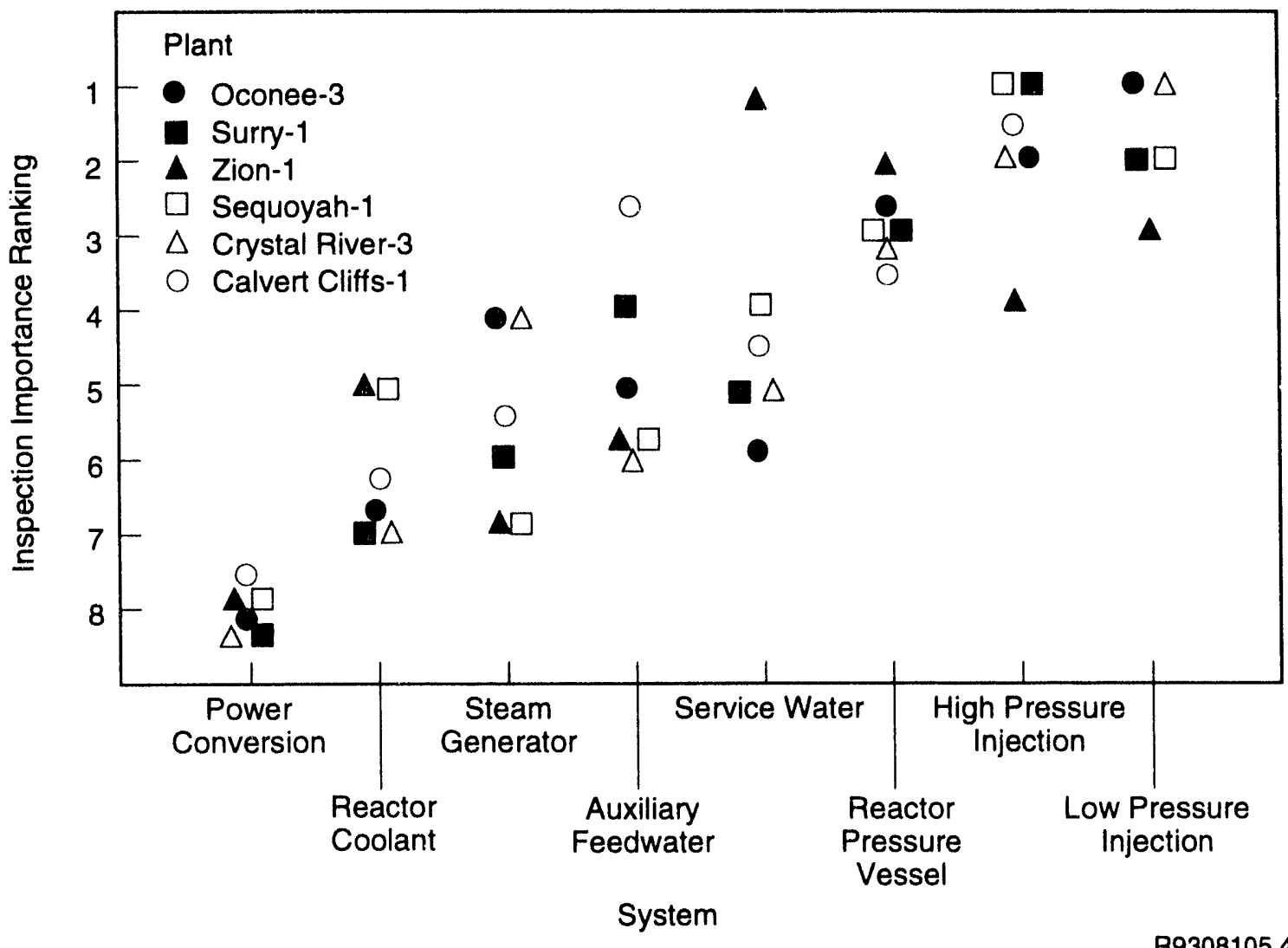

Figure 5.1. Inspection Importance Ranking for Various PWR Systems Based on Core Damage Frequency

that the reactor coolant system at Sequoyah-1 and Zion1 have relatively higher rankings when compared with the other PWRs. This is primarily due to a high possibility of an RCP-seal-failure LOCA event, and the high unavailabilities of systems needed to mitigate an RCP. seal-failure LOCA. A large fraction of this type of LOCA event resulted from a loss of CCW (or service water).

An additional comment is made concerning the reactor coolant system at Sequoyah-1. For the LOCA scenarios (excluding the RCP-seal-failure LOCA), Sequoyah-1 contributes more to the core-damage results because of its ice condenser containment design. In this containment design, the containment sprays are automatically actuated at a lower pressure setpoint than in a corresponding large dry containment design, resulting in containment spray actuation over a larger break size spectrum. This causes faster depletion of the refueling water storage supply and an earlier switch to the recirculation mode. The inclusion of this switchover, which at Sequoyah-1 is a complex manual operation that must be done rather quickly and under stressful conditions, significantly increases the importance of the LOCA sequences, and in turn increases the importance of the reactor coolant system.

Figure 5.2 presents the ranking results for various systems for the five PWRs (in addition to Oconee-3 from the earlier study) selected for the study based on the basis of the Birnbaum Importance Measures. Based on core-damage frequency, this importance measure can be 


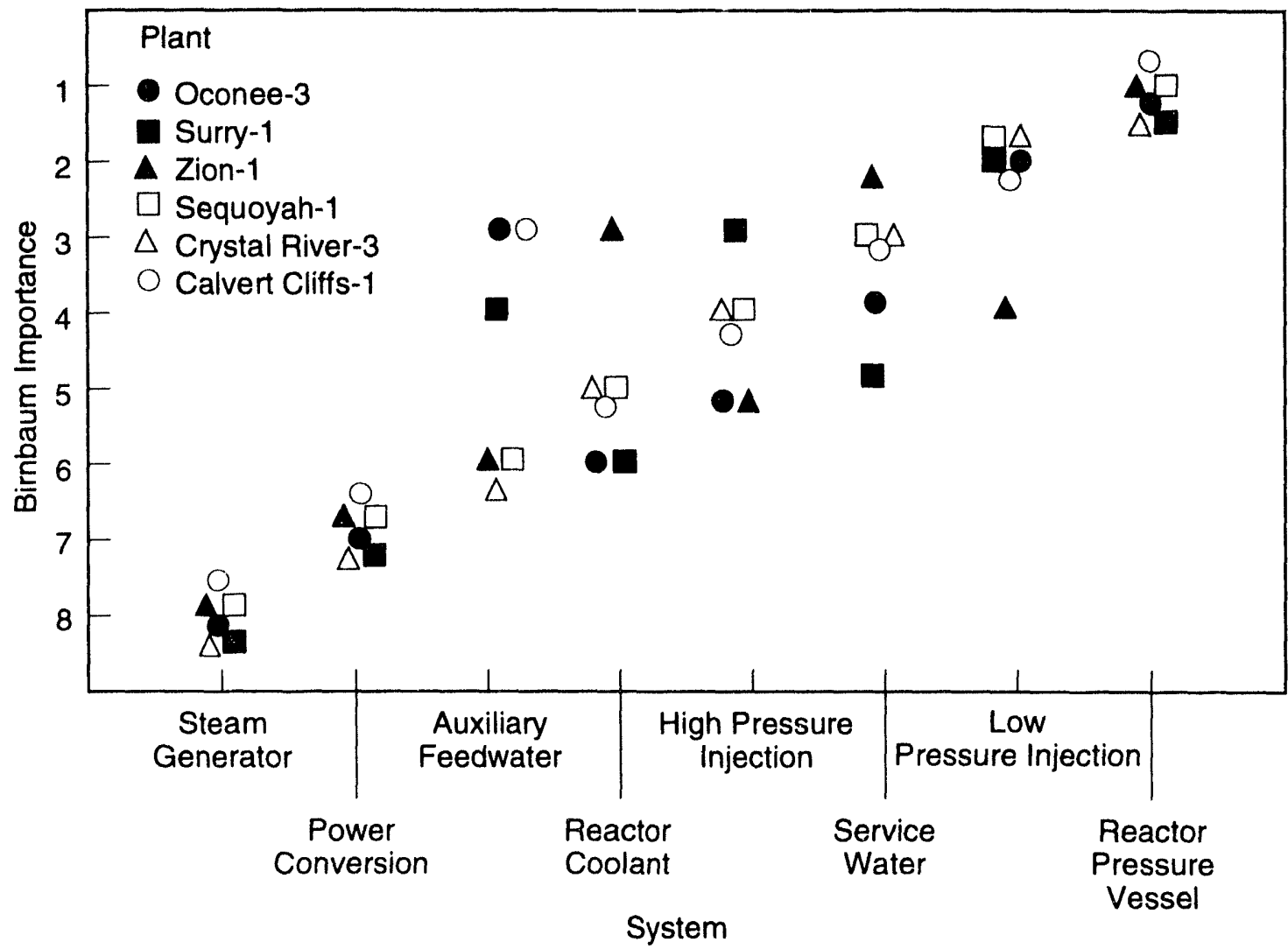

R9308105.3

Figure 5.2. Birnbaum Importance Ranking for Various PWR Systems Based on Core Damage Frequency

interpreted as a conditional probability of core damage given a total system failure. With the exception of some outlier systems similar to those discussed above (e.g., SWS, etc), on the average, the results indicate that the most important systems are the reactor pressure vessel, low-pressure injection, service water, auxiliary feedwater, high-pressure injection, and the reactor coolant systems, since failure of each of these systems would result in a high probability of core damage. Each of the other systems addressed are of lesser importance because of their lower conditional probability of core damage given a total system failure.

\subsection{Summary of Inspection Impor- tance Results for BWR Systems}

Figure 5.3 presents the results of the Inspection Importance analysis of various systems for the two BWRs (Peach Botiom-2 and Grand Gulf-1) selected for the study. Similar to PWRs, system having a lowest rank represents the most important system that needs to be inspected. Based on these results, it appears that most of the safety systems for the two selected BWRs have approximately the same rank. The reactor pressure vessel, the emergency service water, and the high-pressure cooling injection system are the most important systems with respect to pipe failure. Although the reactor pressure vessel is the most important system, it is not a major problem for these plants. Rather, all the 


\subsection{Summary}

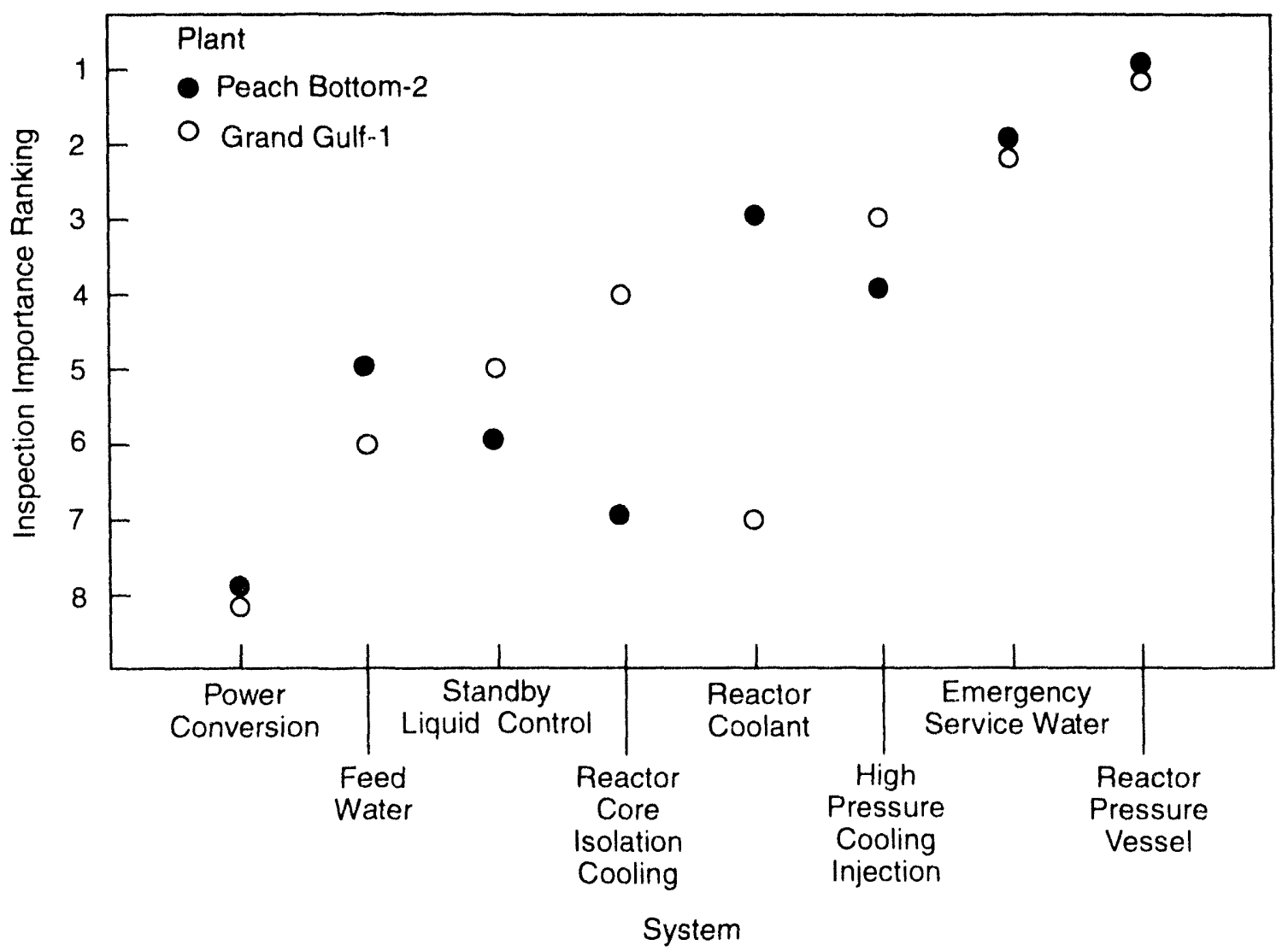

R9308105.1

Figure 5.3. Inspection Importance Ranking for Various BWR Systems Based on Core Damage Frequency

other systems have lower importance as potential contributors to core damage frequency.

The importance of the emergency service water system is primarily due to its important function in providing cooling water to multiple front-line systems or other key support equipment. Emergency service water at these two plants appears in almost all of the accident sequences, where it either directly fails a system or indirectly causes failure through a loss of diesel generator cooling. The importance of the high-pressure cooling injection system is due to its important function in providing coolant to the reactor vessel during accidents in which pressure remains high (e.g., a station blackout event). Examination of Figure 5.3 reveals that the importance measure for the high-pressure cooling injection system at Grand Gulf-1 is slightly higher than at
Peach Bottom-2. The reason for this is that at Grand Gulf-1, the high-pressure cooling injection is susceptible to failure due to high suppression pool temperature. Following a station blackout (about 6 to 8 hours), the suppression pool temperature is in a range of $240^{\circ} \mathrm{F}$ to $280^{\circ} \mathrm{F}$. At these pool temperatures, it was assumed that the high-pressure cooling injection will experience seal failure, thus leading to its unavailability.

The reactor coolant, reactor core isolation cooling, standby liquid control, feedwater, and the power conversion systems following importance. For the reactor coolant system, there is a notable different in rankings between Peach Bottom-2 and Grand Gulf-1 plants. At Grand Gulf-1, the ranking of the RCS is lower than at Peach Bottom-2. This is primarily due to the fact that the LOCA initiating event is not a dominant contributor 
at Grand Gulf-1, and Grand Gulf- 1 is a BWR/6 design. Thus, Grand Gulf-1 uses a motor-driven high-pressure core spray system rather than a steam-driven high-pressure core spray system for high pressure addition of coolant to the reactor vessel. This feature improves the reliability of this system at Grand Gulf-1. In addition, Grand Gulf-1 has a third train of low-pressure coolant injection that injects directly into the reactor core volume. Thus, Grand Gulf-1 has one more train than Peach Bottom-2 for mitigation of large LOCAs.

In contrast, the ranking of the RCIC system at Grand Gulf-1 is higher than at Peach Bottom-2. This is primarily due to differences in containment design and operating procedures. At Grand Gulf-1, the RCIC system is rendered inoperable by the high containment pressurc (i.c., RCIC system fails because of isolation on high turbine exhaust pressure, caused by the increased containment pressure). At Peach Bottom-2, the ability to vent steam from the suppression pool or containment during the course of accident scenario prevents the reactor building from being overpressured. Because of this, various coolant injection systems are not rendered inoperable by the presence of a harsh steam environment. The injection systems also remain accessible to plant personnel. This shows the importance of venting the containment for long-term decay heat removal at a Mark I BWR. The lower importance of the standby liquid control, feedwater, and the power conversion systems are primarily due to the multiplicity and diversity of these systems.

Figure 5.4 presents the rankings for various BWR systems based on the Birnbaum Importance Measures. Based on core-damage frequency, it appears that all safety systems have similar rankings, with some variation in rankings of the RCS and the RCIC systems due to differences in containment design as discussed above. On the average, the results indicate that the most important systems are the reactor pressure vessel, emergency service water, high-pressure cooling injection, reactor coolant, reactor core isolation cooling, and the standby liquid control systems, since failure of each of these systems would result in a high probability of core damage. Each of the other systems addressed are of lesser importance because of their lower conditional probability of core damage given a total system failure.

\subsection{Perspectives}

This section provides a general observation based on the results of plants selected for this study. It is essentia! to note that the results are site-specific; therefore, caution must be exercised when making statements about generic classes of plants, or extrapolating the results of this report to other plants.

As indicated in Figures 5.1 and 5.3, both PWR and BWR results indicate that the support systems in addition to front-line systems are quite important with respect to pipe failure. For instance, at PWR plants, where a single component cooling or service water system is required to provide both methods of reactor coolant pump seal cooling (thermal barrier and seal injection flow), loss of this system is a major contributor to core damage frequency. At plants with two independent cooling systems to support reactor coolant pump seal cooling, and RCP-seal failure LOCA only becomes important in station blackout events. The emergency service water system is important for BWRs because its failure could disable multiple front-line systems or key support systems that are required for an emergency shutdown of the plant.

Differences in containment design can also impact the rankings for safety systems. For PWRs, the pressure setpoint for containment spray actuation is a key factor. Plants with higher setpoints can accommodate largersize breaks without actuation of sprays. Operation of sprays was a determining factor for refueling water storage tank drainage, which forces the switch to the recirculation mode, and leads to increase the importance the emergency core cooling systems. For BWR Mark I containment, successful containment venting can greatly increase the operability of the emergency core cooling systems.

Comparing the results between Figures 5.1 and 5.2 (or Figures 5.3 and 5.4) indicates that the system failure probabilities used could have a significant impact on determining the rankings of safety systems. As recalled from Section 2.3 of this report, the generic piping system failure probabilities were estimated based on the observed pipe failure data in commercial U.S. nuclear power plants obtained from a previous study. Rigorous pipe, failure analysis (e.g., fracture mechanics 


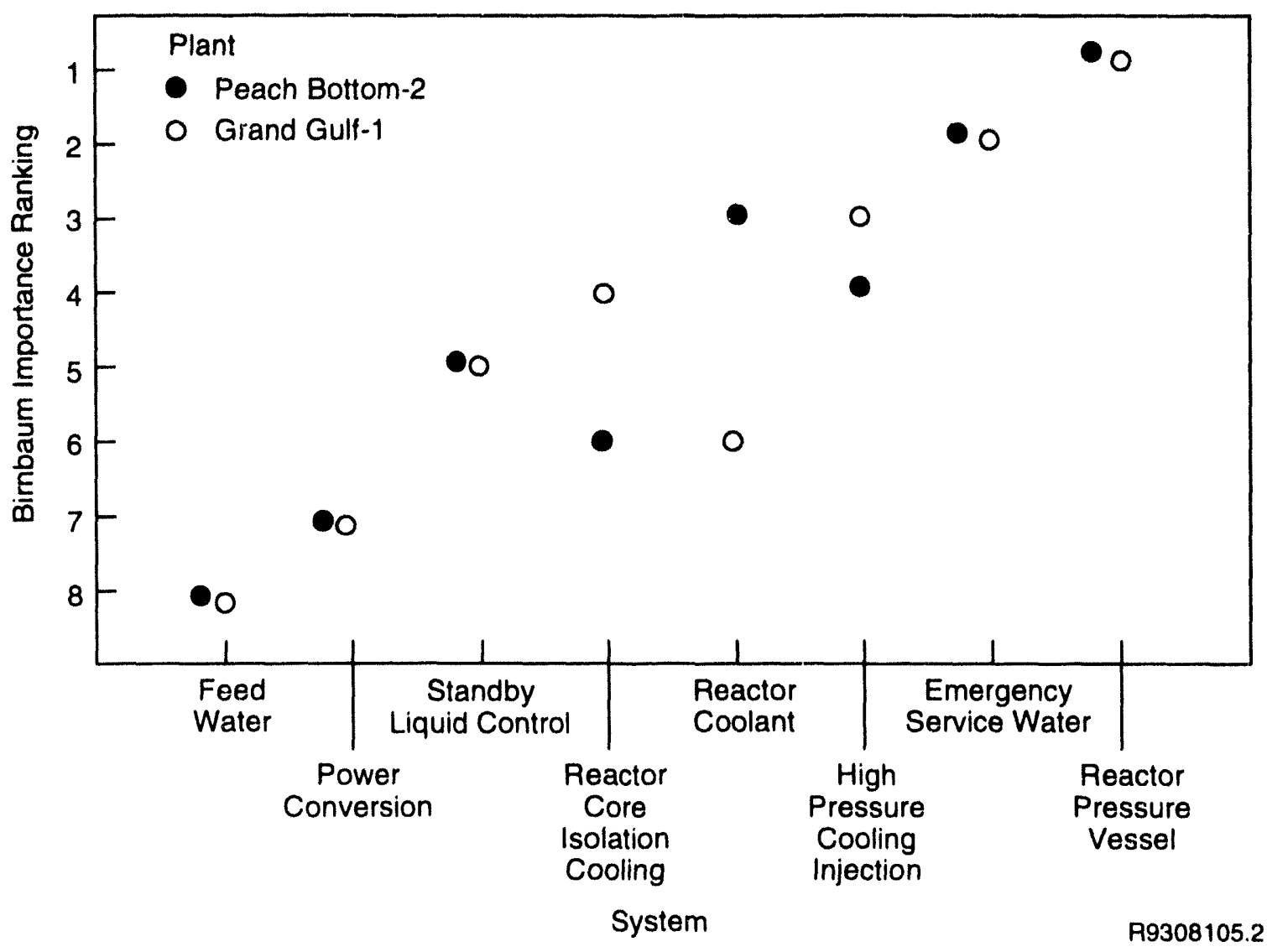

Figure 5.4. Birnbaum Importance Ranking for Various BWR Systems Based on Core Damage Frequency

calculations using actual plant-specific information) may shift the system importance results among plants selected for the study.

Attempts have been made to compare the PRA-based inspection priorities with current ASME Section XI inspection requirements for Class 1,2 , and 3 systems. This could only be done in a very cursory manner because these systems have in many cases sections that are Class 1,2 and 3 so that it makes comparisons complex and not straightforward.

Tables 5.1 and 5.2 present current typical ASME classification and inservice inspection requirements for the PWR and BWR systems listed in Figures 5.1, 5.2, 5.3, and 5.4. Two observations can be made when comparing these tables and figures.
First, the distribution of current ISI inspections among the systems seems to be uniform, with the exception of the Service Water System and Emergency Service Water Systems. This indicates that, at least for the systems that were evaluated, all are considered equally important for inspection purposes and receive a high degree of inspection. This seems to indicate that the Importance Ranking and current ASME ISI requirements generally agree.

Second, based on these calculated importance rankings, some rearrangement of inspection priorities might be appropriate. As an example, inspection emphasis might be shifted from some PCS piping to SWS and EWS piping. However, more detailed component analyses 
Table 5.1. Current ASME Classification and Inservice Inspection Requirements for Various PWR Systems

\begin{tabular}{||l|l|}
\hline System & $\begin{array}{l}\text { ASME Classification/(a) } \\
\text { ISI Examination }\end{array}$ \\
\hline $\begin{array}{l}\text { Low Pressure } \\
\text { Injection }\end{array}$ & $\begin{array}{l}\text { Class I and II } \\
\text { Volumetric and Surface }\end{array}$ \\
\hline $\begin{array}{l}\text { High Pressure } \\
\text { Injection }\end{array}$ & $\begin{array}{l}\text { Class I and II } \\
\text { Volumetric and Surface }\end{array}$ \\
\hline $\begin{array}{l}\text { Reactor Pressure } \\
\text { Vessel }\end{array}$ & $\begin{array}{l}\text { Class I } \\
\text { Volumetric and Surface }\end{array}$ \\
\hline Service Water & $\begin{array}{l}\text { Class III } \\
\text { Visual }\end{array}$ \\
\hline $\begin{array}{l}\text { Auxiliary Feed- } \\
\text { water }\end{array}$ & $\begin{array}{l}\text { Class, I, II, and III } \\
\text { Volumetric and Surface, } \\
\text { Visual }\end{array}$ \\
\hline Steam Generator & $\begin{array}{l}\text { Class I and II } \\
\text { Volumetric and Surface }\end{array}$ \\
\hline Reactor Coolant & $\begin{array}{l}\text { Class I and II } \\
\text { Volumetric and Surface }\end{array}$ \\
\hline Power Conversion & $\begin{array}{l}\text { Class I, II, and III } \\
\text { Surface, Visual }\end{array}$ \\
\hline
\end{tabular}

(a) Classifications represent typical Westinghouse PWR system designs and may vary slightly in specific plants.

of these systems would be required before recommendations for changing inspection requirements could be developed.

Examination of the Inspection Importance numerical results for systems (from Chapter 4.0) indicated that the importance measures for various PWR systems are higher than those of BWRs. The reason for this is that the core damage frequencies for the PWRs are higher than those of BWRs. The LOCA sequences, often dominant in the PWR core damage frequencies, are much less important in the case of the BWRs. That is because the BWRs have multiple and diverse high- and low-pressure emergency core cooling systems, each of which has multiple trains, and a readily available
Table 5.2. Current ASME Classification and Inservice Inspection Requirements for Varlous BWR Systems

\begin{tabular}{|l|l|}
\hline System & $\begin{array}{l}\text { ASME Classification/(a) } \\
\text { ISI Examination }\end{array}$ \\
\hline $\begin{array}{l}\text { Reactor Pressure } \\
\text { Vesscl }\end{array}$ & $\begin{array}{l}\text { Class I } \\
\text { Volumetric and Surface }\end{array}$ \\
\hline $\begin{array}{l}\text { Emergency } \\
\text { Service Water }\end{array}$ & $\begin{array}{l}\text { Class III } \\
\text { Visual }\end{array}$ \\
\hline $\begin{array}{l}\text { High Pressure } \\
\text { Cooling Injection }\end{array}$ & \begin{tabular}{l} 
Class I and II \\
'olumetric and Surface \\
\hline Reactor Coolant \\
Class I \\
Volumetric
\end{tabular} \\
\hline $\begin{array}{l}\text { Reactor Core } \\
\text { Isolation Cooling }\end{array}$ & $\begin{array}{l}\text { Class, I and II } \\
\text { Volumetric and Surface }\end{array}$ \\
\hline $\begin{array}{l}\text { Standby Liquid } \\
\text { Control }\end{array}$ & $\begin{array}{l}\text { Class I and II } \\
\text { Volumetric and Surface }\end{array}$ \\
\hline Feedwater & $\begin{array}{l}\text { Class I and II } \\
\text { Volumetric and Surface }\end{array}$ \\
\hline Power Conversion & $\begin{array}{l}\text { Class I, II, and III } \\
\text { Surface, Visual }\end{array}$ \\
\hline
\end{tabular}

(a) Classifications represent typical Westinghouse BWR system designs and may vary slightly in specific plants.

method of rapid depressurization. Moreover, LOCA events in a BWR can also be mitigated by the main feedwater system, which is both high pressure and high capacity. In contrast, PWRs generally have only one high-pressure and one low-pressure ECC system (both multitrain), plus a set of accumulators. The PWR emergency cooling system does have considerable redundancy, but not as much as that of a BWR.

Although station blackout events contribute a higher percentage of the core-damage frequency for the BWRs sclected for the study, when compared on an absolute rather than relative scale, station blackout is higher in absolute value for PWRs than for BWRs. This is bccause of the PWR's different susceptibilities (particularly the RCP-seal-failure LOCA) and the fact that, unlike 
the BWRs which have at least one injection system that can work during station blackout, PWRs cannot inject directly into the reactor coolant system during a station blackout scenario.

Conversely, BWRs have historically been considered more subject to ATWS events. This is partially due to the fact that some ATWS events in a BWR involve a pressure surge, which can cause a significant insertion of positive reactivity via void coefficient, and result in a rapid power surge. An ATWS event at a PWR is slower, giving more time for mitigation action. However, the two selected BWRs are not dominated by ATWS events. The reason for this is that both of these plants have implemented ATWS modifications, and therefore, the contribution of ATWS to total core damage frequency is lower.

Although not in the scope of this study, human interactions have been found to be extremely important contributors to safety of nuclear power plants. The ability of the operator to actuate alternative systems are crosstied and to recover failed functions can lead to a significant reduction in core-damage frequency. The kcy is having sufficient time and adequate written procedures to support the recovery action. There is significant variability in the quality of the procedures and training from plant to plant.

Sensitivity analyses were only performed on those issues whose potential impact on system ranking was signifi cant. For plants studied, the sensitivity analyses addressed the effects of significant increases of pipe failure probability. This was accomplished by letting the system pipe failure probabilities approach 1.0. This causes $I^{\mathrm{W}}$ values to be the same as $I^{\mathrm{B}}$ values, and the new $I^{\mathrm{w}}$ ranking to be the same as the $\mathrm{I}^{\mathrm{B}}$.

This analysis incorporates information regarding the PRA results and the pipe failure probabilities estimated based on the observed pipe failure data in commercial U.S. nuclear power plants obtained from a previous study. Consequently, the system rankings and their associated numerical results must be considered to be approximate and should be interpreted cautiously. 


\subsection{Summary and Conclusions}

In evaluating approaches that could be used to provide a technical basis for improved ISI plans, PNL has developed and applied a method that uses results of PRA to establish risk-based rankings of pressure boundary system and components. In the PNL program, the feasibility of developing risk-based generic ISI requirements is being accomplished in two phases. Phase I focuses on identifying and prioritizing the generic systems most relevant to plant safety. The overall objective of this phase is to establish the extent to which generic insights drawn from detailed evaluations of selected plants can be extrapolated to different classes of LWRs. Phase Il will focus on analyzing individual welds and components within specific systems. The following provides a summary of the PNL. Phase-I study:

In the Phase I analysis, both the Birnbaum Importance Measurc and Inspection Importance Measure developed by PNL in a previous study were used to identify and prioritize the critical systems for inspection. Physically, lise Inspection Importance Measure is an approximation of corc melt risk due to failures of systems and/or components caused by pipe failures.

Because the scope of the feasibility study does not permit evaluations of all LWRs in the United States, the analyses have focused on inspection for a few well selected plants. The selection criteria included the reactor vendor, the plant type, the A-E, and the availability of a PRA. The analyses began with a review of the commercial LWRs designed by the four reactor vendors. For a given reactor vendor, the specific reactor types were also considered. Because of differences in support system and containment designs, the selection process also considered impacts of A-E design practices. The overall objective was to select a cross section of plants that are representative of all operating reactors. Seven plants (in addition to Oconee-3, which was analyzed in an earlier study) were selected. These plants are listed in Table 3.1.

Figures 5.1 and 5.3 present the results of the Inspection Importance Measures for various safety systems for PWRs and BWRs, respectively. Based on core damage frequency, it appears that most safety systems, in general, have relatively the same rank for plants analyzed. The results also indicate that the key support systems, in addition to the front-line systems are quite important. However, the collective results of the plants se- lected for the study showed variability from plant to plant. Many of the differences in the results can be directly attributed to differences in the PRA results and in plant designs and operational practices.

For the purpose of comparison, the results are also presented on the basis of Birnbaum Importance Measure. This measure can be interpreted as a conditional probability of core damage given a total system failure. Figures 5.2 and 5.4 present the ranking results for various systems of PWRs and BWRs selected for the study. The results also indicate that the front-line and key support systems are important. Again, the collective results showed variability from plant to plant, particular for the key support systems (e.g., Service Water, Auxiliary Feedwater, etc.) due to differences in plant designs and operation.

It is interesting to note that all systems for both plant types, except service water system (PWR) and emergency service water system (BWR), are ranked as important to safety, are currently required to be volumetrically and/or surface examined by Section XI of the ASME Boiler and Pressure Vessel Code (Tables 5.1 and 5.2). The notable exception to the volumetric examination requirement is the service water systems which generally require only a visual examination. On the basis of this study, the service water systems would seem to be candidates for more extensive examination.

Based on the results presented, it appears that there are generic insights that can be extrapolated from the selected plants to specific classes LWRs. However, because the results are site-specific, caution must be exercised when making statements about generic classes of plants, or extrapolating this discussion to all LWRs Information and insights from this study will be compared in future work to results of additional plant-specific studies to validate the preliminary conclusions. The results of these future activities will be consolidated to develop a plan for comprehensive inservice inspection requirements that will be formulated in Phase II of the PNL study.

In general, it has been concluded that 1) the methodology developed by PNL has been demonstrated to be a useful tool for identifying generic systems in nuclear power plants that need to be inspected, 2) the insights gained about the important features are useful in focusing attention on important matters and design details 


\subsection{Summary and Conclusions}

and, therefore, can serve as a foundation for future study. The extent to which generic insights can be drawn from the eight plant analyses, and the degree to which this information and plant specific results can then be applied to other operating plants often resides in the nature of the specific issue being addressed.

Generic conclusions will remain unclear until a systematic evaluation of the sensitivity of the results to plantspecific design factors and operating procedures can be made. What can be stated is that this study provided a resource that can be used to address many present-day regulatory considerations that exist within the NRC's licensing, inspection, and research responsibilities.
Specifically, detailed information is presented that can be of great assistance to the NRC in major activities to develop the methodology and data to set priorities for inspection activities, and the coordination of research programs that address revisions to the ASME Code.

In future work, validating current results, detailed plant system analyses, improved piping failure analyses, cost and benefit analyses, and other analytical methods will be used to analyze the major systems in the selected plants. The results of these future activities will be used to develop improved plans for comprehensive inservice inspection requirements for pressure boundary systems and components at light-water reactors. 


\subsection{References}

ANS. 1988. Commercial Nuclear Power Stations in the United States-Operable, Under Construction or Ordered August 1, 1988. American Nuclear Society, LaGrange Park, Illinois.

Bertucio, R. C, M. D. Quilici, J. Young, and F. T. Harper. 1986a. Analysis of Core Damage Frequency From Internal Events: Surry, Unit 1. NUREG/ CR-4550, Volume 3, Sandia National Laboratory, Albuquerque, New Mexico.

Bertucio, R. C, D. L. Moore, J. T. Held, T. J. Leahy, F. T. Harper, and A. L. Camp. 1986b. Analysis of Core Damage Frequency From Internal Events: Sequoyah, Unit 1. NUREG/CR-4550, Volume 3, Sandia National Laboratory, Albuquerque, New Mexico.

Drouin, M. T., J. L. LaChance, B. J. Shapiro, F. T. Harper, and T. A. Wheeler. 1986. Analysis of Core Damage Frequency from Internal Events: Grand Gulf, Unit 1. NUREG/CR-4550, Volume 6, Sandia National Laboratory, Albuquerque, New Mexico.

Florida Power Corporation. 1987. Crystal River, Unit 3 Probabilistic Risk Assessment. Saint Petersburg, Florida.

Kolaczkowski, A. M., J. A. Lambright, W. L. Farrell, N. G. Cathey, B. Najafi, and F. T. Harper. 1986. Analysis of Core Damage Frequency From Internal Events: Peach Bottom, Unit-2. NUREG/CR-4550, Volume 4, Sandia National Laboratory, Albuquerque, New Mexico.

Payne, A. C., et al. 1984. Interim Reliability Program: Analysis of the Calvert Cliffs, Unit I Nuclear Power Plant. NUREG/CR-3511, Sandia National Laboratory, Albuquerque, New Mexico.
Vesely, W. E., T. C. Davis, R. S. Denning, and N. Saltos. 1983. Measures of Risk Importance and Their Applications. Battelle Columbus Laboratories, Columbus, Ohio.

Vo, T. V., B. F. Gore, L. J. Eschbach, and F. A. Simonen. 1989a. "PRA-Based Guidance for Piping Inservice Inspection." Nuclear Technology, September 1989, Volume 88, Number 1, American Nuclear Society, LaGrange Park, Illinois.

Vo, T. V., M. S. Harris, and B. F. Gore. 1989b. PRA Application Program for Inspection at Calvert Cliffs, Unit 1 Nuclear Power Plant. NUREG/CR-5187, Pacific Northwest Laboratory, Richland, Washington.

Vo, T. V., M. S. Harris, and B. F. Gore. 1989d. "Probabilistic Risk Assessment Based Inspection Guidance for Arkansas Nuclear One Unit 1." Nuclear Technology, 1989 Volume 84, Number 1, American Nuclear Society, LaGrange Park, Illinois.

Wheeler, T. A. 1986. Analysis of Core Damage Frequency from Internal Events: Zion, Unit 1.

NUREG/CR-4550, Volume 7, Sandia National Laboratory, Albuquerque, New Mexico.

Wright, R. E., J. A. Steverson, and W. F. Zuroff. 1987. Pipe Break Frequency Estimation for Nuclear Power Plants. NUREG/CR-4407, Idaho National Engineering Laboratory, Idaho Falls, Idaho.

U.S. Nuclear Regulatory Commission (NRC). 1975. Reactor Safety Study--An Assessment of Accident Risk in U.S. Commercial Nuclear Power Plants. WASH 1400, NUREG-75/014, Washington, D.C. 


\subsection{References}

ANS. 1988. Commercial Nuclear Power Stations in the United States-Operable, Under Construction or Ordered August 1, 1988. American Nuclear Society, LaGrange Park, Illinois.

Bertucio, R. C, M. D. Quilici, J. Young, and F. T. Harper. 1986a. Analysis of Core Damage Frequency From Intemal Events: Surny, Unit i. NUREG/ CR-4550, Volume 3, Sandia National Laboratory, Albuquerque, New Mexico.

Bertucio, R. C, D. L. Moore, J. T. Held, T. J. Leahy, F. T. Harper, and A. L. Camp. 1986b. Analysis of Core Damage Frequency From Internal Events: Sequoyah, Unit 1. NUREG/CR-4550, Volume 3, Sandia National Laboratory, Albuquerque, New Mexico.

Drouin, M. T., J. L. LaChance, B. J. Shapiro, F. T. Harper, and T. A. Wheeler. 1986. Analysis of Core Damage Frequency from Intermal Events: Grand Gulf, Unit 1. NUREG/CR-4550, Volume 6, Sandia National Laboratory, Albuquerque, New Mexico.

Florida Power Corporation. 1987. Crystal River, Unit 3 Probabilistic Risk Assessment. Saint Petersburg, Florida.

Kolaczkowski, A. M., J. A. Lambright, W. L. Farrell, N. G. Cathey, B. Najafi, and F. T. Harper. 1986. Analysis of Core Damage Frequency From Intemal Events: Peach Bottom, Unit-2. NUREG/CR-4550, Volume 4, Sandia National Laboratory, Albuquerque, New Mexico.

Payne, A. C., et al. 1984. Interim Reliability Program: Analysis of the Calvert Cliffs, Unit 1 Nuclear Power Plant. NUREG/CR-3511, Sandia National Laboratory, Albuquerque, New Mexico.
Vesely, W. E., T. C. Davis, R. S. Denning, and N. Saltos. 1983. Measures of Risk Importance and Their Applications. Battelle Columbus Laboratories, Columbus, Ohio.

Vo, T. V., B. F. Gore, L. J. Eschbach, and F. A. Simonen. 1989a. "PRA-Based Guidance for Piping Inservice Inspection." Nuclear Technology, September 1989, Volume 88, Number 1, American Nuclear Society, LaGrange Park, Illinois.

Vo, T. V., M. S. Harris, and B. F. Gore. 1989b. PRA Application Program for Inspection at Calvert Cliffs, Unit 1 Nuclear Power Plant. NUREG/CR-5187, Pacific Northwest Laboratory, Richland, Washington.

Vo, T. V., M. S. Harris, and B. F. Gore. 1989d. "Probabilistic Risk Assessment Based Inspection Guidance for Arkansas Nuclear One Unit 1." Nuclear Technology, 1989 Volume 84, Number 1, American Nuclear Society, LaGrange Park, Illinois.

Wheeler, T. A. 1986. Analysis of Core Damage Frequency from Internal Events: Zion, Unit 1. NUREG/CR-4550, Volume 7, Sandia National Laboratory, Albuquerque, New Mexico.

Wright, R. E., J. A. Steverson, and W. F. Zuroff. 1987. Pipe Braak Frequency Estimation for Nuclear Power Plants. NUREG/CR-4407, Idaho National Engineering Laboratory, Idaho Falls, Idaho.

U.S. Nuclear Regulatory Commission (NRC). 1975. Reactor Safety Study--An Assessment of Accident Risk in U.S. Commercial Nuclear Power Plants. WASH 1400, NUREG-75/014, Washington, D.C. 


\section{Appendix A}

\section{Surry-1 System Importance Calculations}

This appendix discusses the importance measures calculations performed for the Surry-1. The calculations were performed using a LOTUS spreadsheet with the cut sets shown in NUREG/CR-4550, Analysis of Core Damage Frequency from Internal Events: Surry, Unit 1 (Bertucio et al. 1986a).

The core damage frequency of Surry-1 was dominated by transient-initiated accident sequences. This accounts for approximately 68 percent of the mean of the total core damage frequency. The lesser contributions are from LOCA-initiated sequences (both inside and outside containment) comprise 32 percent of the total core damage frequency.

Of the contribution from transients, station blackout sequences as a group are the largest contributor to core damage frequency ( 38 percent). Station blackout is defined as a loss of all AC power (except vital AC supplied through DC inverters). This is caused by loss of off-site power and the subsequent. failure of both diesel generators. The largest sequence frequency attributed io a station blackout was involved in reactor pump seal LOCA due to the failure of all seal coolirig. In this sequence, high-pressure injection and containment systems are unavailable due to the extended unavailability of $\mathrm{AC}$ power. Other core damage sequences resulting from station blackout are the extended unavailability of $A C$ power and eventual station battery depletion, or failure of the auxiliary feedwater system in the short term due to failure of the turbine-driven pump.

Core damage sequences resulting from degraded electrical power supplies comprise another 25 percent of the total core damage frequency. The dominant sequences in this group involve loss of a $480 \mathrm{~V} \mathrm{AC}$ electrical bus, followed by failure of a pressurizer relief valve to close, and failure of long-term recirculation core cooling due to failure of high-pressure recirculation system or the low-pressure recirculation system. The remaining sequences in this group are initiated by a loss of off-site power, followed by failure of auxiliary feedwater system and the inability to open both poweroperated relief valves (PORVs), thus preventing feedand-bleed cooling.
LOCA sequences, both inside and outside containment, comprise about one-third of the total core damage frequency. The highest LOCA sequence frequency involves a very small LOCA (equivalent diameter of a break less than $1 / 2$ inch) with failure of high-pressure injection. Other contributors in this group include small-, intermediate-, or large-size LOCAs followed by failure of high-pressure injection or recirculation core cooling. Interfacing system LOCAs comprise 4 percent of the total core damage frequency.

The remaining core damage are ATWS (anticipated transients without scram) sequences. These sequences involve transients followed by failure to scram the reactor and then failure of emergency boration. ATWS sequences comprise about 6 percent of the total core damage frequency.

The Surry-1 PRA contains 125 cut sets as shown in Table A.1. These cut sets are a combination of 94 modules or individual events. The Surry-1 PRA contains nine initiating events as shown in Table A.2. Each initiating event and module were assigned to a plant system and a category number. The systems and their category number were:

System Category

$\begin{array}{lr}\text { High-Pressure Injection (HPI) } & 1 \\ \text { Low-Pressure Injection (LPI) } & 2 \\ \text { Auxiliary Feedwater (AFW) } & 3 \\ \text { Reactor Coolant (RCS) } & 4 \\ \text { Charging Pump Cooling (CPC) } & 5 \\ \text { Power Conversion (PCS) } & 6 \\ \text { Service Water (SWS) } & 7 \\ \text { AC Power } & 8 \\ \text { Reactor Protection System (RPS) } & 9 \\ \text { Human Error } & 10 \\ \text { DC Power } & 11 \\ \text { Component Cooling Water (CCW) } & 12\end{array}$




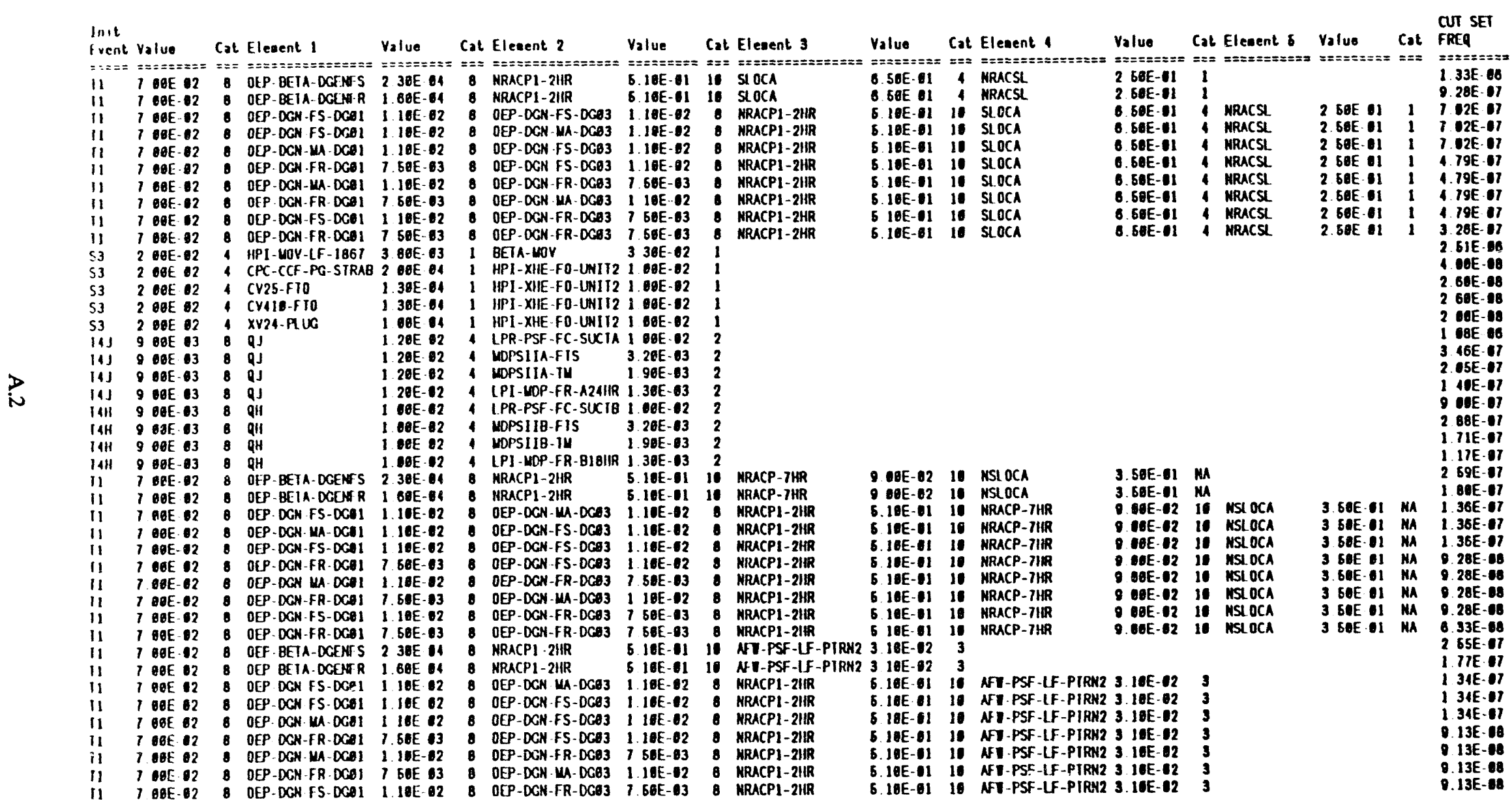


Table A.1. Surry-1 Cut Sets (cont'd)

Init

Value Cat Elenent 2

Value Cat Elenent 3

Value Cat Eleaent

Value

Cat Elesent 5 Valuo

Event $Y_{2} l$ lo

\begin{tabular}{|c|c|c|c|c|c|c|c|c|c|c|c|c|c|}
\hline 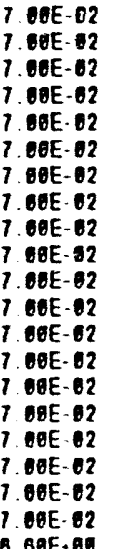 & 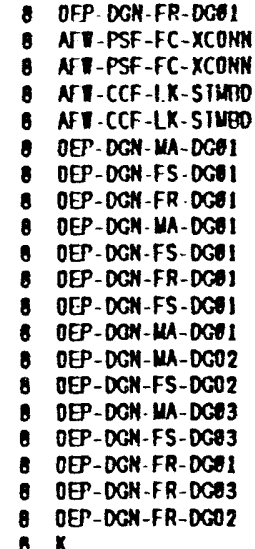 & 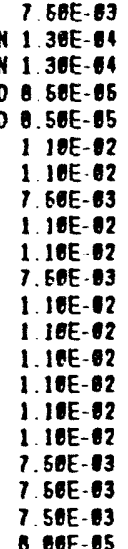 & $\begin{array}{l}8 \\
3 \\
3 \\
3 \\
3 \\
8 \\
8 \\
8 \\
: \\
: \\
: \\
: \\
8 \\
8 \\
: \\
: \\
: \\
:\end{array}$ & 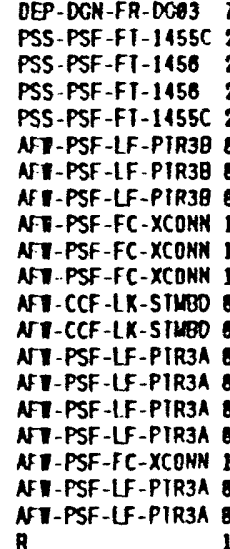 & 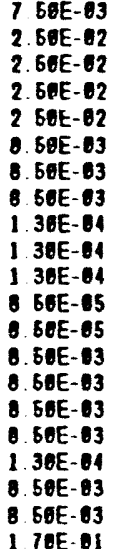 & $\begin{array}{l}0 \\
4 \\
1 \\
1 \\
3 \\
3 \\
3 \\
3 \\
3 \\
3 \\
3 \\
3 \\
3 \\
3 \\
3 \\
3 \\
3 \\
3\end{array}$ & 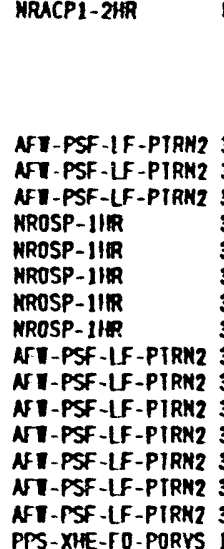 & 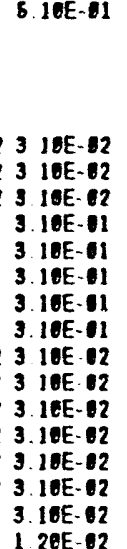 & $\begin{array}{r}3 \\
3 \\
3 \\
10 \\
10 \\
16 \\
10 \\
10 \\
3 \\
3 \\
3 \\
3 \\
3 \\
3 \\
3\end{array}$ & $\begin{array}{l}\text { PPS- WOV-FC-1536 } \\
\text { PPS- WOV-FC-1536 } \\
\text { PPS- WOV-FC-1536 } \\
\text { PPS- WOV-FC-1536 } \\
\text { PFS - MOV-FC-1536 } \\
\text { PPS - WOV-FC-1536 } \\
\text { PPS- WOV FC-1536 }\end{array}$ & 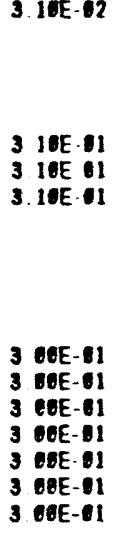 & $\begin{array}{l}4 \\
4 \\
4 \\
1\end{array}$ & $\begin{array}{l}\text { MROSP-1HR } \\
\text { WROSP-1HR } \\
\text { WROSP-IIR } \\
\text { NROSP-1HR } \\
\text { MROSP-1HR } \\
\text { WROSP-11HR } \\
\text { WROSP-1HR }\end{array}$ \\
\hline
\end{tabular}

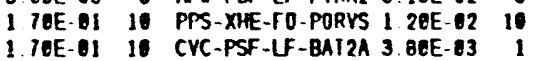

6. 60E.60

LPI-CKY-RP-SI85 1 20E-01 2 I.PI-CKY-LK-51243 4.4EE-83

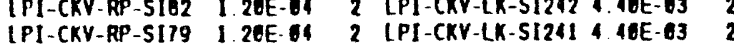

IPI-CKV-FT-SI243 1 30E-04 \& LPI-CKV-RP-SIBS $120 E$ O4 2

IPI-CKV-FT-SIOS 1 .30E-04 2 L LPI-CKV-RP-SI243 $1.20 E-042$

LPI-CXY-FI-S1242 1. 30E 012 2 LPI-CKY-RP-S182 1.20E-O4 2

IFI-CKV-FT-S182 1.30E-04 2 LPI-CKV-RP-S1242 1.20E-04 2

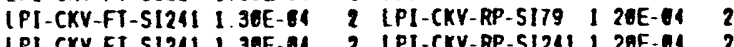

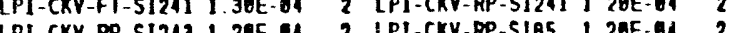

LPI-CKY-RP-SI243 $120 E-642$ IPI-CKY-RP-SIBS $1206-121$

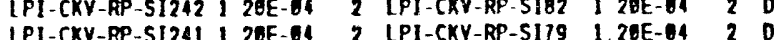

5 LEE 12

$\begin{array}{ll}\text { 6 ERE-11 } & 2 \\ 5.0 Q E-11 & 2\end{array}$

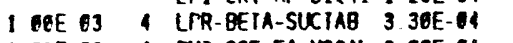

$1.06 E-034$ RNI-CCF-FA- MSCAL 3 BQE-64

1 OOE.03 LPR-PSF-FC-SUCIA 1 10E-02 2 LPI-PSF-LF-PIRNB $3206-032$

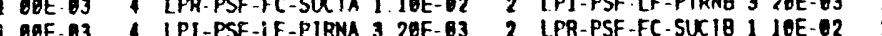

9 GOE 03 Q $120 E$ O2 1 HRP-PSF-LF-SUCTA 5 SOE-03

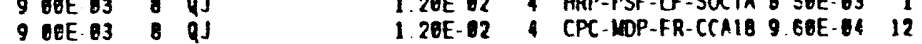

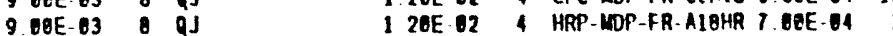

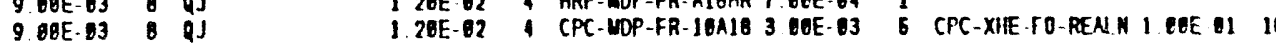

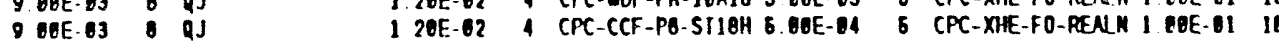

1. 60 E3 1 LPR-BETA-SUCTAB 3 36E-61 2

1 GOE.83 I RWT-CEF-TA-KSCN. 3 BOE-OI

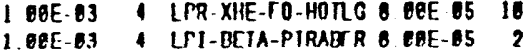

3 IOE $1110 \quad 18900$

3 IOE 1110900

3 IOE 01 is 1 29E- 10

3. IEE- 11 10 $129 E-08$

1
1
1

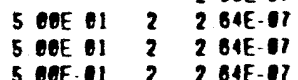

$2.04 E-O 1$
$1.56 E-O B$

$156 E-98$

S6E- 98

1 SGE 100

1 S6E-
1 S6E
1

720609

7.2009

3 20E- 300

$330 \mathrm{E}-9$

3 OOE 17

1 SOE-TI

3 B2E-CO

G(E-)

$1 . M E-O 1$

$166 \mathrm{E}-10$

3 $24 \mathrm{E}-00$

3 उOE. $O 1$

3 OOE $O 1$

1.0E-106 
Table A.1. Surry-1 Cut Sets (cont'd)

Init
Erent valuo

Cat Elenent 1

Valuo Cat Elewent 2

Value Cat Eleaent 3

Value Cat Eleaent 1

Value

Cat Elewent 5 value

\begin{tabular}{|c|c|c|c|c|c|c|c|c|c|c|c|c|c|}
\hline & & & & & & & & & & & & & \\
\hline S1 & BEE-63 & 4 & & & & & & & & & & & \\
\hline 51 & 1800.03 & 1 & CPE-CCF-MO-SIRAB & $B E$ & & 5 & & & & & & & \\
\hline si & $180 E-63$ & $i$ & IIFI-BETA-1087 & $1.20 E-$ & & 1 & & & & & & & \\
\hline 52 & $1000-63$ & $i$ & HPI- KSF-FL-PSUCI & & & $i$ & & & & & & & \\
\hline s2 & 1 EE- 83 & 4 & CPC-CCF-PQ-SIRAA & $2 \mathrm{BEE}$ & & 5 & & & & & & & \\
\hline 52 & 168083 & $i$ & HPI-BEIA-186TCD & $1200-$ & -84 & $i$ & & & & & & & \\
\hline TAH & 2 OBE-63 & : & QIII & $1.08 \mathrm{E}-$ & & 1 & IIRP-PSF-LF-SUCIB & $560 E-03$ & 1 & & & & \\
\hline TAN & 9 BAE- 63 & 8 & an & $1.00 E-$ & & 1 & CPC-MDP-FR-CCB1B & $9.60 E-04$ & 12 & & & & \\
\hline $\mathrm{TAH}$ & $960 E-63$ & 8 & Qii & 1. BOE- & & 1 & HRP-MOP-FR-BIBHR & $1.06-04$ & 1 & & & & \\
\hline TAII & $980 E-03$ & 8 & Qil & i $60 \mathrm{E}$. & & 4 & CPC - WDP-FR-18B1B & 3. $66 \mathrm{E}-63$ & 5 & CPC-XHE-FO-REN N & $1160 E-61$ & 10 & \\
\hline INH & $9.60 E-63$ & 8 & gil & $180 E$. & & $i$ & CPC-CCF-PB-SIIBII & $500 E-04$ & 5 & CPC-XHE-FO-RENN & 1 CEE 01 & is & \\
\hline 1 & $340 E .80$ & & $x$ & O.OOE. & & & R & 1.76E-61 & 10 & $z$ & 1. $40 E-02$ & 4 & \\
\hline$\lambda$ & $800 E-84$ & $i$ & $A C C-P S F-I F-A C C B$ & 3 96E. & & 2 & & & & & & & \\
\hline$A$ & & 1 & ACC-PSF-LF-ACCC & $3.96 E-$ & & 2 & & & & & & & \\
\hline$A$ & $5.60 E-04$ & 1 & LTR-BEIA-SUCIAB & 3 3EE & & 2 & & & & & & & \\
\hline A & 8 BEE- 84 & $i$ & RNI-CCF-FA-NSCAL & $3 \mathrm{BOE}$ & & 1 & & & & & & & \\
\hline$A$ & 5 BOE O4 & & LPR-XIE-TO-HOILO & $8 \mathrm{COE}-$ & -85 & 10 & & & & & & & \\
\hline$A$ & 660084 & 4 & IPI-BEIA-PIRAEFR & $10.00 E-$ & 85 & 2 & & & & & & & \\
\hline 52 & & 4 & HRP BE IA-SUCIAB & $1.80 E-$ & & 1 & & & & & & & \\
\hline 52 & i 80803 & $i$ & HRP-BEIA-MOFFRI8 & $5 \mathrm{BBE}-$ & & 1 & & & & & & & \\
\hline 52 & 1 (.)BE-63 & 4 & CPC CCF-TO-SIIEH & $1668 \mathrm{E}$. & & 5 & & & & & & & \\
\hline s2 & I EQE 03 & $i$ & CPC-BETA-SIABRIB & $3.18 E$ & 85 & $i$ & & & & & & & \\
\hline s2 & $160 E-63$ & & CPC BEIA-CCABRIO & & & 12 & & & & & & & \\
\hline in & $100 E .02$ & $\theta$ & OEP BEIA-DGENTS & 2.36E- & -14 & 8 & PPS-SOV-CO-1158 & 1. $38 E \cdot 02$ & 4 & NRACPIHAR & $316 E-11$ & 10 & \\
\hline II & i BOE 02 & 8 & OEP - BE1A-DCENFR R & $1 \mathrm{EBE}$ & 01 & 8 & PPS-SOV-CO-1150 & 1. $38 E-62$ & 4 & NRACPIIIR & $316 E 01$ & 16 & \\
\hline Ii & 7 Q8E-62 & 8 & OFF-DCH - FS - DCO1 & i. $10 E-$ & & & OEP-DGH UA-DGE3 & $1,18 E-02$ & 8 & PPS-SOV-CO-1658 & 1. $3 E E 2$ & 1 & MRACPIHR \\
\hline iI & $1000-82$ & 8 & OET DCN UA DCE1 & 1 18E- & -62 & 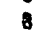 & OEP-DCN-FS DGOS & $1.180-02$ & 0 & PPS-SOV-CO-1456 & 1. $36 \mathrm{E}-2$ & 4 & NRACPIHR \\
\hline iI & & 8 & OEP-DCN-FS-DCE1 & 1 10E- & & & OEP-DCN-FS-DGE3 & i $18 E-82$ & 0 & PPS-SOV-CO-1458 & 1.30E. 02 & $i$ & NRACPIHR \\
\hline ii & 7000.02 & $:$ & DEP-DCN-TR-DCOI & $7.58 E$ & & 8 & OEP-DCN-FS-DCE3 & 1 18E- 82 & g & PPS-SOV-CO-1456 & $136 E-02$ & 1 & MRACPIHR \\
\hline$i 1$ & 7 BOE 02 & 8 & OEF - DGN - MA DGBI & I $10 E$ & 02 & 8 & OEP-DGN-FR DGE3 & i $58 E-83$ & $\theta$ & Prs-50V-CO-1450 & $136 E .82$ & 1 & NRACPIHR \\
\hline ii & 7 OBE & & OLP DCH.FR DCE1 & $7 \mathrm{SBE}$. & & & DEP-DGN YA-DGO3 & $110 E-82$ & $B$ & PFS-SOY-CO-1158 & $130 E=2$ & & MRACPIHR \\
\hline 11 & & : & OEP - DCN IS - DCOI & & & & OEP - DCN FR DCB3 & i SeE. 03 & & PPS-SOV CO-14S6 & $130 E .82$ & & NRACPIHR \\
\hline$n$ & & & DEF- DGN-FP-DGOI & & & & OEP-DCH-FR-DCQ3 & $758 E-83$ & 8 & FPS-SOV-CO-1150 & $130 E \cdot 2$ & 4 & NRACPIHR \\
\hline$\leq 0$ & $200 \mathrm{OE}$ & 8 & $F_{2 i l}$ IFI & $1 \mathrm{BOE}$. & 01 & $i$ & SO-SV deaznd & $1800-01$ & 8 & SG SV lzil open & 5 QEE 83 & 8 & \\
\hline & $2.0 P E-02$ & 0 & NI İil & 2 OEE- & -64 & 3 & SG-SV demand & 1. $2 B E \cdot 01$ & 6 & SG-SV fail open & 5. $29 \mathrm{E}-03$ & 8 & \\
\hline
\end{tabular}

3 JOE of 10

3. 10E it 10

10E 11

3 IEE 10

3 IOE 1110

3 IOE OI 18

3 IEE. Q1

OnE.

1 20E- 11

3 LOE. 01

2 QOE OI

20E of

GAE "l

OAE- 10

$30 E-60$

SUE.

1 S6E $\theta$

1 9SE- $\theta 1$

1 OSE OT

1 BSE.

I SOE. OI

1 OOE- 10

OOE- 00

$860-07$

5 OOE 00

5 OOE 91

IEE 10

3 2EE
$O S O E$

$+51 E$ : 18

$3.11 E-00$

3 IIE 00

3 IIE 08

$233 E 68$

$233 \mathrm{E} .8$

$233 E 86$

2 I3E 68

1 SGE :8

2 BOE 99

CORE NE I I RLQUTCMCY

$2 \div$ 19E- 05 
Table A.2. Surry-1 Initiating Events

\begin{tabular}{|c|c|c|}
\hline Label & $\begin{array}{l}\text { Category } \\
\text { Number }\end{array}$ & Description \\
\hline S1 & 4 & Medium LOCA \\
\hline S2 & 4 & Small Medium LOCA \\
\hline S3 & 4 & Very Small LOCA \\
\hline $\mathbf{A}$ & 4 & Large LOCA \\
\hline SGTR & 6 & $\begin{array}{l}\text { Steam Generator Tube } \\
\text { Rupture }\end{array}$ \\
\hline$I_{1}$ & 8 & Loss of AC Off-site Power \\
\hline $\mathrm{T}_{4 \mathrm{I}}$ & 8 & Loss of 480 VAC Bus $1 \mathrm{H}$ \\
\hline$\Gamma_{4 J}$ & 8 & Loss of 480 VAC Bus $1 \mathrm{~J}$ \\
\hline
\end{tabular}

\section{A.1 Surry-1 System Importance Analysis}

Utilizing the method described in Chapter 2.0 of this report and the cut sets shown in the Surry-1 PRA (NUREG/CR-4550), the Inspection Importance for Surry-1 systems were calculated. The Inspection Importance Measure, $I^{w}$, for a given system was defined as the product of the system Birnbaum Importance $\left(\mathrm{I}^{\mathrm{B}}\right)$ times the estimated pipe failure probability $\left(\mathrm{P}_{i}\right)$ for that system. The calculations were based on the total core damage frequency (Level I PRA). The following paragraphs describe the Surry-1 system I ${ }^{\mathrm{w}}$ calculations.

The first step in the calculations was to calculate the present level of risk, $R_{0}$. This was accomplished by inputting the cut sets from the PRA, referencing the cut set elements to a table of probabilities or unavailabilities for modules and/or components shown, calculating the cut set frequency, and then summing the cut set frequencies to obtain the plant total core melt frequency. The value obtained for these calculations was $2.49 \mathrm{E}-05 / \mathrm{py}$, which is within reasonable agreement with the value 2.6E-05/py reported in NUREG/CR-4550. The primary difference is the roundoff error from using module values as compared to calculating values from the basic events.

In order to simplify the analysis and to ensure that naming was consistent throughout the report, specifically for the case that failure of one system could cause failure of another system, prioritization of systems were based on the total contribution of these system failures.
In the calculations for those systems that did not fit specifically, or wholly, into one of the general categories, the systems were first assigned to the individual system identified for the plant specific PRA. Then the Birnbaum Importances were combined into the common categories used for all plants before the Inspection Importance Measures were calculated. For instance, the SWS and the CCW are support systems. In general, these systems perform the same function, (i.e., provide heat removal function from the important frontline systems). They may be identified as two separate systems in one plant and as a composite system in another plant. In some plants, failure of the SWS may cause a failure of the CCW system, therefore, the importance of the SWS in those plants included a contribution from the importance of the CCW system.

The Birnbaum Importance calculations began by assigning each of the elements of the cut set to a category as shown in Table A.1. For instance, all cut set elements associated with the failure of the High-Pressure Injection system were assigned to category 1 . The calculations were performed for the risk increase, the risk reduction, and the Birnbaum Importance Measures. A LOTUS-based computer program was developed for the analysis. A spreadsheet was used to allow the calculations to be performed.

The risk increase is defined by Vesely (Vesely et al. 1983) to be the increase in risk if the component or system were assumed not to be there or to be failed. On an interval scale the risk increase, $A$, of component $i$ is defined as:

$$
A_{i}=R_{i}^{+}-R_{o}
$$

where $R_{0}$ is the present, or reference risk level

failed.

$R_{i}^{+}$is the risk level with component $i$ assumed

For a cut set, the risk increase represents the increase in the total cut set frequency if the probability of the event of interest was increased to a value of 1.0. For this study, the risk increase for a system (e.g. the HPI) was calculated as the sum of the risk increases of the components. The risk increase is calculated by individ- 


\section{Appendix A}

ually substituting a value of unity for the unavailability for each component in system. Then the cut set frequency was recalculated and the reference risk subtracted to obtain the risk increase for the component. This calculation was performed for each component in the system. The risk increases, $A_{i}$, for each of the components were then sorted by category and summed to obtain the risk increase for each system.

The risk reduction is defined to be the decrease in risk if the component $i$ was assumed to be optimized or was assumed to be made perfectly reliable. On an interval scale, the risk reduction $D_{i}$ is:

$$
\mathrm{D}_{\mathrm{i}}=\mathbf{R}_{\mathrm{o}}-\mathbf{R}_{\mathrm{i}}^{-}
$$

where $R_{0}$ is the present risk level as above

$R_{i}$ is the risk level with component $i$ assumed working perfectly.
The risk reduction is calculated by substituting zero for the unavailability of each component belonging to the system of interest. Then the cut set frequency is recalculated and subtracted from the reference risk, $\mathbf{R}_{\mathbf{0}}$. The risk reduction represents the decrease in the total cut set frequency calculated if the probability for each component of the system of interest were decreased to a value of 0.0 .

The Birnbaum Importance of component $i$ is the sum of the risk increase and reduction for component $i$.

$$
I_{i}^{B}=A_{i}+D_{i}
$$

The Birnbaum Importance for each system was then calculated by summing the risk increase and the risk reduction. The Birnbaum Importance Measure can be interpreted as the interval change in risk between the system being perfectly reliable and a total system failure. When risk is measured by core melt frequency, the Birnbaum Importance of a system is equivalent to the conditional probability of core melt given a system failure.

\begin{tabular}{|c|c|c|c|c|c|}
\hline System & A & Rank & D & Rank & $I^{\mathrm{B}}$ \\
\hline RPS & $2.6 \mathrm{E}-02$ & 1 & $1.6 \mathrm{E}-06$ & 7 & $2.6 \mathrm{E}-06$ \\
\hline $\mathrm{AC}$ & $1.8 \mathrm{E}-02$ & 2 & $9.9 \mathrm{E}-06$ & 4 & $1.8 \mathrm{E}-02$ \\
\hline LPI & $1.6 \mathrm{E}-02$ & 3 & $5.7 \mathrm{E}-06$ & 5 & $1.6 \mathrm{E}-02$ \\
\hline HPI & $1.4 \mathrm{E}-02^{(\mathrm{a})}$ & 4 & $1.4 \mathrm{E}-05$ & 2 & $1.4 \mathrm{E}-02$ \\
\hline AFW & $8.2 \mathrm{E}-03$ & 5 & $2.4 \mathrm{E}-06$ & 6 & $8.2 \mathrm{E}-03$ \\
\hline sws & $2.2 \mathrm{E}-03^{(\mathrm{b})}$ & 6 & $1.4 \mathrm{E}-07$ & 8 & $2.2 \mathrm{E}-03$ \\
\hline HRE & $1.6 \mathrm{E}-03$ & 7 & $1.2 \mathrm{E}-05$ & 3 & $1.6 \mathrm{E}-03$ \\
\hline RCS & $5.9 \mathrm{E}-04$ & 8 & $2.0 \mathrm{E}-05$ & 1 & $6.1 \mathrm{E}-04$ \\
\hline PCS & $3.5 \mathrm{E}-06$ & 9 & $1.6 \mathrm{E}-06$ & 9 & $5.1 \mathrm{E}-06$ \\
\hline SG & $3.5 \mathrm{E}-06^{(c)}$ & 10 & $1.6 \mathrm{E}-06$ & 10 & $5.1 \mathrm{E}-06$ \\
\hline
\end{tabular}

Table A.3. Summary of Importance Measures for Surry-1 Systems

(a) Includes contribution of CPC system.

(b) Includes contribution of CCW system.

(c) Calculates separately, based on initiating event and SG-SVs failure frequencies. 
The results of the Risk Increase (A), the Risk Reduction (D) as well as the Birnbaum Importance Measures for the Surry-1 systems are presented in Table A.3. Table A.4 shows the ranking results based on the Codetype ISI systems. In this table the RPV system is also included. For this analysis, the conditional probability of a core melt if the RPV fails is assumed to be 1.0, and thus the Birnbaum Importance for the RPV is 1.0.

\section{A.2 Inspection Importance Calcu- lations}

Using the system Birnbaum Importance Measures presented in Table A.4, and the system pipe failure probabilities $\left(P_{i}\right)$ presented in Table A.5, the $I^{\mathbf{w}}$ for systems were calculated (e.g., the product of the system $\mathrm{I}^{\mathrm{B}}$ and $\left.\mathrm{P}_{\mathrm{i}}\right)$. The $\mathrm{I}^{\mathrm{W}}$ results for various systems at Surry-1 are presented in Table A.6 and are ranked in order of decreasing impact.

Table A.4. Birnbaum Importance Ranking for Surry-1 Systems ${ }^{(a)}$

System
$\begin{aligned} & \text { Reactor Pressure Vessel } \\ & \text { (RPV) }\end{aligned}$

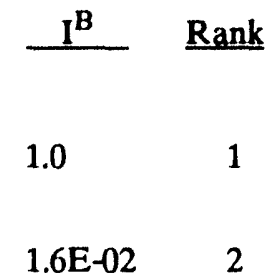

Low-Pressure Injection

$1.0 \quad 1$

High-Pressure Injection

Auxiliary Feedwater

(AWF)

Service Water (SWS)

8.2E-03 4

Reactor Coolant (RCS)

Power Conversion

(PCS)

Steam Generator (SG)

2.2E-03 5

$6.1 \mathrm{E}-04 \quad 6$

\section{$1.4 \mathrm{E}-02 \quad 3$}

$6.1 \mathrm{E}-04-6$

5.1E-06 7

5.1E-06 8

(a) Only systems of interest to Code-Type-ISI are listed. The Bimbaum Importance for the RPV system was assumed to be 1.0 .

Table A.S. Estimated Pipe Failure Probabilities for PWR Piplng Systems ${ }^{(a)}$

\begin{tabular}{lc}
\multicolumn{1}{c}{ System } & $\begin{array}{c}\text { Pipe Failure } \\
\text { Probability } \\
\text { (per plant) }\end{array}$ \\
\cline { 2 - 2 } Steam Generator (SG) & $1.0 \mathrm{E}-02$ \\
High-Pressure Injection (HPI) & $9.5 \mathrm{E}-04$ \\
Low-Pressure Injection (LPI) & $3.8 \mathrm{E}-04$ \\
Power Conversion (PCS) & $3.8 \mathrm{E}-04$ \\
Auxiliary Feedwater (AFW) & $4.7 \mathrm{E}-05$ \\
Service Water (SWS) & $4.7 \mathrm{E}-05$ \\
Reactor Coolant (RCS) & $4.7 \mathrm{E}-05$ \\
Reactor Pressure Vessel (RPV) & $5.0 \mathrm{E}-06$
\end{tabular}

(a) Obtained from NUREG/CR-5272, Table 3.2.

Table A.6. Inspection Importance Ranking for Surry-1 Systems

\begin{tabular}{lcc} 
System & \multicolumn{1}{c}{$I^{\mathrm{w}}$} & Rank \\
\cline { 2 - 3 } HPI & $1.3 \mathrm{E}-05$ & 1 \\
LPI & $6.1 \mathrm{E}-06$ & 2 \\
RPV & $5.0 \mathrm{E}-06$ & 3 \\
AFW & $3.9 \mathrm{E}-07$ & 4 \\
SWS & $1.0 \mathrm{E}-07$ & 5 \\
SG & $5.1 \mathrm{E}-08$ & 6 \\
RCS & $2.9 \mathrm{E}-08$ & 7 \\
PCS & $1.9 \mathrm{E}-09$ & 8
\end{tabular}




\section{Appendix B}

\section{System Description and Function}

\section{B.1 PWR Plant System Description}

\section{B.1.1 Reactor Pressure Vessel}

The reactor pressure vessel (RPV) is a principal component of the reactor coolant system. The RPVs for the three reactor suppliers are quite similar. The pressure vessel is cylindrical with a hemispherical bottom head, and a flanged and gasketed removable upper head. The vessel contains the core, core support structures, control rods, thermal shield, and other parts directly associated with the core. Outlet and inlet nozzles are located at an elevation between the head flange and the core.

Most of the vessels have been designed and manufactured to the requirements of Section III of the ASME Boiler and Pressure Vessel Code. The body of the RPV is low alloy carbon steel. Inside surfaces in contact with coolant are clad austenitic stainless steel to minimize corrosion. To achieve high core outlet temperatures without boiling, the coolant must be maintained at high pressures. This pressure, typically about 2200 psia, in turn mandates that the reactor be placed in a thick-walled steel vessel.

The core is housed below the nozzles and above the bottom hemispherical head. A thermal shicld, integral with the lower core support barrel assembly, forms an annular flow channel that routes the coolant to the core. The reactor vessel internals are designed to withstand forces due to weight, preload of the fucl assemblies, control rod dynamic loading, vibration, and earthquake acceleration.

The fucl elements of all PWRs are similar; all utilize uranium dioxide pellets enriched to 2 to 4 percent, clad in Zircaloy tubes of about the same diameter. A square array of fuel rods structurally bound together constitutes a fuel assembly. The control rod drive mechanisms are positioned on the upper vessel head. In-core flux measuring instrumentation penetrations are located in the bottom head of the vessel.

PWRs are depressurized and the reactor vessel head removed every 12 to 18 months for partial refueling.
During the regular refueling operations, the reactor vessel head is visually inspected. Samplings of the vessel head hold-down studs undergo visual, magnetic particle, and ultrasonic tests during each refueling operation. All of the studs are subjected to these tests at least once in every 10-year period.

\section{B.1.2 Reactor Coolant System}

The function of the reactor coolant system (RCS) is to remove heat and transfer it to the secondary system. It also provides a barrier against the release of reactor coolant or radioactive material to the containment environment.

The RCS for PWRs consists of two to four identical heat transfer loops (connecting parallel to the reactor pressure vessel), each of which includes a steam generator, reactor coolant pump(s) plus connecting piping and instrumentation for flow and temperature measurements. The pipes through which the heated water flows from the RPV to the steam generator are called the "hot leg" and the pipes through which the cooled water flows from the steam generator and back into the RPV are called the "cold leg." The working fluid is boiled on the secondary sides of the steam generator and transported through a conventional turbine-condenser system.

The RCS also includes a pressurizer that maintains the reactor coolant at a constant pressure. The pressurizer system consists of power operated relief valves with associated block valves, ASME code safety valves, pressurizer sprays, and electrical heaters. A pressurizer controls the primary system pressure through electrical heater and spray cooling of the water and steam inventory of a chamber. The pressurizer is connected to a coolant loop but is maintained at the saturation temperature that corresponds to the system pressure.

To regulate the reactor coolant chemistry within design limits and control the pressurizer level, a constant letdown flow from one loop upstream of the RCP is maintained. This flow is, in turn, controlled by the pressurizer level. Constant coolant makeup is added by charging pumps in the chemical and control volume system. 


\section{B.1.3 Steam Generators}

Steam generators (SGs) transfer heat from primary coolant to secondary feedwater in order to generate steam for driving the turbine-generator. PWR steam generators are normally shell-and-tube heat exchangers with high-pressure primary water passing through the tube side and lower pressure secondary feedwater and steam passing through the shell side. In addition to providing steam, SGs also function as a barrier between the radioactive primary coolant and the seconaary coolant.

PWR nuclear steam supply systems incorporate two or more SGs in order to reduce equipment size and increase plant safety through redundant systems. Babcock and Wilcox and Combustion Engineering PWR systems use two steam generators while Westinghouse systems incorporate two, three, or four SGs depending upon plant size.

Both Combustion Engineering and Westinghouse plants use a vertical U-tube steam generators. Hot leg primary coolant enters the steam generator inlet nozzle and flows upward through the tubes to the top of the Utube bundle and then downward to exit from the outlet nozzle. Feedwater enters the side of the SG and continues flow upward as it gains energy until it flows past the tube bundle where a water level is maintained above the tube and below the moisture separators. Wet saturated steam passes through the moisture separators where the majority of entrained water is removed. Entrained water from the moisture separators flows downward through a down-comer and mixes with the incoming feedwater.

Babcock and Wilcox employs a once-through steam generator. Hot leg primary coolant enters the top of the steam generator through a single inlet nozzle and flows downward through the tubes, discharging through the outlet nozzles. Feedwater enters the side of the steam generator and flows downward along the shell until it reaches the tubesheet. Flow is then upward countercurrent to the primary coolant. As the feedwater flows upward through the shell side it is converted to steam and then superheated. At the top of the tube bundle the superheated steam flow is outward toward the shell and then downward in the annular region formed by the shell and upper baffle to the outlet nozzles.

\section{B.1.4 High-Pressure Injection/Recircula- tion System}

The function of the high pressure injection/recirculation (HPI/HPR) system is to provide primary coolant injection and recirculation following an accident, as well as maintaining flow to the RCP seals. The HPI system also functions to deliver boric acid to the RCS from the boric acid transfer system if emergency boration is required.

Under normal operating conditions, the HPI system uses one of the charging pumps to provide normal RCS makeup and cooling to the RCP seals by taking suction from the volume control tank.

Upon indication of a loss of RCS coolant or steam line break, the safety injection actuation system (SIAS) initiates emergency coolant injection. In the recirculation mode of operation, the charging pumps draw suction from the discharge of the low-pressure safety injection pumps in the low pressure recirculation system. Upon receipt of a low RWST level signal, the charging pump suction valves from the RWST are closed and the suction valves from the LPR pump discharge are opened.

In the emergency boration mode, the HPI functions as described in the HPI description above with the exception that the boric acid transfer (BAT) pumps deliver boric acid from the BAT tanks to the charging pump suction header. To perform this operation, the operator actions may be required to switch the normally operating BAT pump to fast speed operation and open the MOV allowing flow into the charging pump suction header.

In general, the $\mathrm{HPI} / \mathrm{H}^{\mathrm{P}} \mathrm{R}$ system interfaces with the containment spray system (CSS) and the low-pressure injection system at the common RWST. The HPR system interfaces with the low-pressure recirculation system at the recirculation suction valves. 


\section{B.1.5 Low-Pressure Injection/Recircula- tion System}

The low-pressure injection/recirculation (LPI/LPR) system provides emergency coolant injection and recirculation following a LOCA when the RCS depressurizes below the low-pressure setpoint (about 300 psig). In addition to the direct recirculation of coolant during the recirculation phase once the RCS is depressurized, the LPR discharge provides the suction source for the HPR system following drainage of the RWST.

A typical LPI/LPR system consists of two 100 percent capacity pump trains. In the injection mode, the pump trains share a common suction header from the RWST. Each pump draws suction from the header through a normally open MOV, check valve, and locked open manual valves. Each pump discharges through a check valve and normally open MOV in series to a common injection header. The injection header contains a locked open MOV and branches to separate lines, one to each cold leg. Each of the lines to the cold legs contain two check valves in series to provide isolation from the high pressure RCS.

In the recirculation mode, the purnp trains draw suction from the containment sump through a parallel arrangement of suction lines to a common header. Flow from the suction header is drawn through a normally closed MOV and check valve in scries. Discharge of the pumps is directed to either the cold legs through the same lines used for injection or to a parallel set of headers which feed the charging pumps, depending on the RCS pressure.

Upon indication of a loss of RCS coolant or a main steam line break, the SIAS initiates LPI operation. The SLAS signals the low-pressure pumps to start. All valves are normally aligned to their injection position. If primary system pressure remains above the LPI pump shutoff head, the pumps will discharge to the RWST through two normally open minimum flow recirculation lines until the RCS pressure is sufficiently reduced to allow inflow. Upon receipt of a low RWST level signal, the low pressure pump suction valves from the RWST and the valves in the minimum flow recirculation lines to the RWST are closed and the suction valves from the containment sump are opened.
The LPI/LPR system interfaces with the CSS and the high-pressure injection system at the common RWST. The LPR system interfaces with the high-pressure recirculation system at the recirculation suction valves.

\section{B.1.6 Auxiliary Feedwater System}

The auxiliary feedwater (AFW) system provides feedwater to the stcam generators to provide heat removal from the primary system after reactor trip. The AFW is a multiple train system; it consists of electric motordriven pumps and steam turbine driven pump. Each pump draws suction through an independent line from the condensate storage tank (CST). Each AFW pump discharges to parallel headers. Each of these headers can provide auxiliary feedwater flow to any or all of the steam generators. Flow from each header to any one SG is through a normally open MOV and a locked open valve in series, paralleled with a line from the other header. These lines feed one line containing a check valve that joins the main feedwater line to a steam generator.

The motor-driven AFW pumps automatically start on receipt of an SIAS signal, loss of main feedwater, low steam generator level in any steam generator, or loss of off-site power. The turbine-driven AFW pump automatically starts on receipt of indication of low steam generator level in any steam generator or undervoltage of any of the main RCS pumps.

The AFW system is dependent on the AC power buses for motive power to the AFW motor driven pumps and motive and control power to the AFW MOVS, the DC power buses for control power to the AFW pumps, and the SIAS for actuation of the AFW pumps. The turbine driven pump turbine inlet valves require instrument air as well as DC power for control, however, on loss of either instrument air or DC power the valves fail open allowing steam flow to the pump turbine.

\section{B.1.7 Cooling Water-Component Cooling Water, Service Water System}

Cooling water for normally operating and standby components and systems is supplied by the component cooling water (CCW) system and the service water system (SWS). In general, the CCW system is a closedloop system. The CCW system removes heat from 
various components and is cooled via $\mathrm{CCW}$ heat exchangers, which are, in turn, cooled by the SWS. A typical CCW system consists of three pumps and heat exchangers. Normally one pump and one heat exchangcr can handle the heat removal loads during normal operation. During normal operation, the CCW system provides cooling water to the reactor coolant and charging pumps. Two CCW pumps and heat exchangers are utilized for removing residual heat and pump heat during normal plant shutdown.

The SWS provides cooling water to several plant equipment including the $\mathrm{CCW}$ system to the ultimate heat sink. The SWS is, in general, an open-loop system. The SWS also serves as a backup supply to the auxiliary feedwater system and/or provides heat removal from the containment following an accident at some plants. The cooling system is dependent on the AC power buses for motive control power to the system pumps and MOVS.

\section{B.1.8 Power Conversion System}

The function of the power conversion system (PCS) is to transform thermal energy from the RCS through the steam generators into electrical energy. A typical PCS consists of the main steam supply system, main turbinegenerator, the main feedwater pumps, the condensate pumps, the condensate booster pumps, and the hotwell inventory.

The PCS is a closed cycle. Condensate is drawn from the hot well of the condenser and pumped via the condensate pumps through the steam jet air ejector condensers and gland steam condensers. This condensate is pumped via the condensate booster pumps through several stages of low-pressure feedwater heacers. From this point the water is pumped via feedwater pumps through high-pressure heaters through the regulating valves to the steam generators.

In the steam generators, the feedwater is converted to steam. The steam exits the steam generators via main steamlines that are equipped with power-operated atmospheric relief valves, safety valves, and isolation valves. From this point, the steam passes via piping inside a tunnel through combination of stop and throttle valves and governor valves to the high- and low-pressure turbines.
Throughout the portion of the steam cycle dowrstream of the isolation valves, steam is extracted at various points to operate auxiliaries and to supply heat to the condenser and feedwater heaters. Steam used for this purpose is returned to the cycle for reuse. The PCS depends on a number of interfacing systems to successfully fulfill its design function.

\section{B.2 BWR Plant System Description}

\section{B.2.1 Reactor Pressure Vessel}

The RPV is a principal component of the reactor coolant system. The vessel, in general, contains the core and supporting structures, steam separators and dryers, jet pumps, control rod guide tubes, distribution of lines for safety injection or recirculation systems, and other parts directly associated with the core.

Most of the RPVs have been designed and fabricated in accordance with the requirements of Section III of the ASME Boiler and Pressure Vessel Code. The BWR differs from the PWR in that bulk boiling of the coolant takes place as it passes through the reactor core. The pressure of a BWR is less than one-half of a PWR, for although the two systems have a comparable core outlet temperatures of about $600^{\circ} \mathrm{F}$, the BWR is at the coolant saturation pressure. As a result, the BWR reactor vessel is substantially thinner than that of PWR. On the other hand, the placement of the steam separation equipment results in the BWR vessel having a substantially larger volume.

The fuel elements of BWRs are similar to those for PWRs. The fuel assemblies for BWRs are enclosed in channel boxes or shrouding that also permits the control of the power-to-flow ratio within individual assemblies by orificing the channel box inlets. Curiform control rods are placed between the assemblies. They enter from the bottom of the core for power shaping purposes.

Similar to PWRs, BWRs are depressurized and the reactor vessel head removed every 12 to 18 months for partial refueling. During the regular refueling operations, the reactor vessel head is visually inspected. All of the studs are subjected to surface and volumetric nondestructive tests at least once in every 10-year period. 


\section{B.2.2 Reactor Coolant System}

The function of the reactor coolant system (RCS) or reactor circulation system is to provide a continuous internal coolant circulation for a major portion of the core. The RCS consists of two recirculation pump loops external to the reactor vessel. These loops provide the piping path for the driving flow of water to the reactor vessel jet pumps. Each external loop contains one high capacity motor-driven recirculation pump, two motor-operated valves, and one hydraulically operated now control value.

The jet pumps are reactor vessel internals. The jet pumps provide a continuous internal circulation path for the major portion of the core coolant flow. The jet pumps are located in the annular region between the core shroud and the vessel inner wall. Any circulation line break would still allow core flooding to approximately two-thirds of the corc height (level of the inlet of the jet pumps).

\section{B.2.3 High-Pressure Cooling Injection System}

The function of the high-pressure cooling injection (HPCI) system is to provide coolant to the reactor vessel during accidents in which pressure remains high. In general, the HPCI consists of a single train with MOVs and a motor-driven pump. Suction is taken from either the condensate storage tank (CST) or the suppression pool. Injection to the RPV is via a spray ring mounted inside the core shroud.

The HPCI system is automatically initiated and controlled. However, operator intervention is required to throttle flow to prevent the HPCI injection valve from opening and closing in response to the reactor vessel level. The operator may also be required to manually start the system if an automatic start failure occurs.

The HPCI system major dependencies are the DC control power for initiating the actuation relay logic and HPCl pump breaker, AC power for operating the HPCI pump and valves, and the HPCI pump room cooling.

\section{B.2.4 Reactor Core Isolation System}

The function of the RCIC system is similar to the function of the HPCl system, with the exception that the $\mathrm{RCIC}$ system provides a lower flow rate. The RCIC system consists of a single train with motor-operated valves and a turbine-driven pump. Suction is taken from either the CST or the suppression pool. The RCIC pump can deliver about $825 \mathrm{gpm}$ at any pressurc greater than 200 psig.

The RCIC system is automatically initiated and controlled. However, operator intervention is required as follows: 1) to prevent either vessel overfill or continuous system trip/restart cycles, 2) to manually start the system given an auto-start failure, and 3) to set up the system for continuous operation when battery depletion is imminent.

The RCIC system major dependencies are DC power for short-term operation and room cooling for long term operation (room cooling requires $A C$ power). The RCIC and HPCl system share a common CST suction valve. Failure of this valve $u \cdot i l$ fail the CST as a suction source to both the RCIC and HPCl systems.

\section{B.2.5 Emergency Service Water System}

The function of the emergency service water (ESW) system is to provide heat removal from plant auxiliaries that require cooling during an emergency shutdown of the plant. A typical ESW system is made up of three independent trains. Each train consists of a motordriven pump, motor-operated valves, and heat exchangcrs.

The ESW pumps are vertical, centrifugal pumps, each pump takes suction from the cooling tower basins, circulates water through the heat exchangers for each load, and returns the water to the towers through the discharge valve. The ESW is automatically initiated and controlled; however, operator intervention is required to manually start the system given an auto-start failure.

The ESW system major dependencies are DC control power for initiating the actuation relay logic and $A C$ power for operating the ESW pumps and valves. The pumps are generally self-cooled. 


\section{B.2.6 Standby Liquid Control System}

The standby liquid control (SLC) system provides a backup method, which is redundant but independent of the control rods, to establish and maintain the reactor subcritical.

The suction for the SLC system comes from the SLC tank. The control tank has sodium pentaborate in solution with demineralized water. Two parallel, positive displacement pumps, each inject the sodium pentaborate solution into the reactor. The pump suctions are cross-tied to ensure suction to both pumps if one of the suction valves fails closed. Two parallel explosive valves are downstream of the pump discharge. A crosstie line upstream of the explosive valves is present to ensure that flow from either pump can be discharged through either explosive valve. Downstream of the explosive valves, the system combines to a common discharge line. The SLC discharges into the reactor vessel lower plenum where it mixes with cooling water rising through the core.

The operator manually activates the SLC system with two keylock switches on the control room console (one for each train). If the pump,lights or the explosive valve light indicate the liquid may not be flowing in one train, the operator can turn the keylock swith to initiate the other train.

The SLC control tank outlet valves are cross-tied so that opening of either valve will provide solution to both SLC pumps. The major dependency is AC power for operating the SLC pumps and valves. The pumps are generally self-cooled and do not require room cooling.

\section{B.2.7 Feedwater/Condensate System}

The function of the feedwater/condensate (FW/CD) system is to provide cooling water from the main condenser to the RPV to be converted to steam. This system is operating during normal plant conditions. Upon a reactor scram resulting in loss of feedwater, the condensate system continues to function, recirculating condensate to the condenser. The operator can establish condensate flow to the reactor vessel by opening the feedwater startup valve.
A typical FW/CD system has two turbine-driven feedwater pumps, three condensate pumps, three condensate booster pumps, three strings of four low-pressure heaters, a condensate drain tank and associated valves, piping, instrumentation, and controls to supply the reactor feed pumps with heated feedwater at the necessary net positive suction head. The condensate system also supplies water to the reactor vessel during lowpressure conditions such as startups, shutdowns, and, in emergency situations, through the feedwater startup valve.

The FW/CD system depends on a number of interfacing sysicms to successfully fulfili its design function.

\section{B.2.8 Power Conversion/Main Steam System}

The function of the power conversion/main steam system (PCS/MSS) is to transform thermal energy from the RCS into electrical energy. A typical PCS/MSS consists of the main steam system, the main turbinegenerator, the turbine bypass valves, and the main condenser.

The main steam system consists of main steam lines from the outermost containment isolation valves to the main steam stop valves, and connecting lines to supply steam to the second stage reheater, the condenser steam jet air ejectors, the main turbine bypass valves, the reactor feed-pump turbines, and the seal steam evaporator.

The main condenser is, in general, a three shell, series flow, triple pressure design, with shells arranged beneath the low-pressure elements of the turbine and tubes oriented transversely to the turbine axis. Deaeration in each shell provides for removal of normal air inleakage plus hydrogen and oxygen gases contained in the turbine steam due to ridiological dissociation of water in the reactor. The PCS/MSS depends on several safety-related systems to successfully fulfill its design function. 


\section{DISTRIBUTION}

No. of

Copies

\section{OFFSITE}

L. Abramson NRC/RES

Mail Stop NS 372

2 A. J. Hiser, Jr. NRC/RES

Mail Stop NS 217C

M. R. Hum NRC/NRR

Mail Stop 7 D4

G. Johnson

NRC/RES

Mail Stop 7 D4

G. C. Millman

NRC/RES

Mail Stop NS 217B

J. Muscara

NRC/RES

Mail Stop NS 217C

C. Z. Serpan

NRC/RES

Mail Stop NS 217C

D. E. Smith

NRC/NRR

Mail Stop 7 D4

J. Strosnider

NRC/NRR

Mail Stop 7 D4

J. P. Durr

NRC/Region I
No. of

Copies

M. C. Modes

NRC/Region I

A. R. Herdt

NRC/Region II

J. J. Blake

NRC/Region II

J. Jacobson

NRC/Region III

F. Ammirato

EPRI

1300 Harris Blvd.

PO Box 217097

Charlotte, NC 28221

R. Art

ASME Center for Research \& Technology Development 1828 L St. NW Suite 906

Washington, DC 20036-5104

B. M. Ayyub Dept. of Civil Engineering University of Maryland College Park, MD 20742

K. R. Balkey

Westinghouse Energy Center

PO Box 355

Pittsburgh, PA 15230-0355

W. Bamford

Westinghouse Energy Systems

STC Bldg. 701-401

PO Box 2728

Pittsburgh, PA 15230 
Distribution

No. of

No. of

Copies

Copies

B. A. Bishop

Westinghouse Elec. Corp.

Nuclear \& Adv. Tech. Div.

PO Box 355

Pittsburgh, PA 15230-0355

J. D. Boardman

San Onofre Nuclear Gen. St.

PO Box 128

San Clemente, CA 92672

R. J. Bosnak

8226 Stone Trail Drive

Bethesda, MD 20817

J. F. Cook

Idaho National Engrg Lab

PO Box 1625

Idaho Falls, ID 83415-3855

C. D. Cowfer

Westinghouse Savannah

MS 703-13C

PO Box 616

Aiken, SC 29802

A. Deardorf

Structural Integrity Assoc.

\#145

3150 Almaden Expressway

San Jose, CA 95718

D. Gallino

Gilbert/Commonwealth

525 Lancaster Ave.

Reading, FA 19603

R. Gamble

Sartnex Corporation

1700 Rockville Pike

Suite 400

Rockville, MD 20852

D. Harris

Failure Analysis Assoc. Inc.

149 Commonwealth Drive

PO Box 3015

Menlo Park, CA 94025

O. F. Hedden

ABB Combustion Engrg.

Nuclear Power Dept. 9500-2408

1000 Prospect Hill Road

Windsor, CT 06095-0500

K. Jamali

US Dept of Energy

OES - DP62/GTN

Washington, DC 20585

D. Karydas

Factory Mutual Research Corp.

PO Box 9102

Norwood, MA 01061

J. Lance

EPRI

1300 Harris Blvd.

PO Box 217097

Charlotte, NC 28221

A. L. Mackinney

Nuclear Mgmt \& Resources Council 1776 Eye Street NW

Suite 300

Washington, DC 20006-3706

L. Mathews

Southern Nuclear Operating

Company

PO Box 1295

Birmingham, AL 35201

D. A. Mauney

Carolina Power \& Light Co.

Energy \& Environ. Center

Route 1

Box 327

New Hill, NC 27562

Distr.2 
Distribution

No. of

Copies

A. McNeil Virginia Elec. Power Co.

5000 Old Dominion Blvd.

Glen Allen, VA 23060

E. Michalopoulos

The Hartford Steam Boiler

Inspection \& Insurance Co.

One State Street

Hartford, CT 06102

G. N. Miller

Edison Electric Inst.

701 Pennsylvania Ave NW

Washington, DC 20004

J. H. Phillips

TENERA

477 Shoup Ave.

Suite 201

Idaho Falls, ID 83402

P. Riccardella

Structural Integrity Assoc.

\#145

3150 Almaden Expressway

San Jose, CA 95718

L. Sage

Illinois Dept. of Nuclear

Safety

1035 Outer Park Drive

Springfield, IL 62704

M. E. G. Schmidt

Industrial Risk Insurers

85 Woodland Street

Hartford, CT 06102

N. Siu

Idaho National Engrg Lab

PO Box 1625

Idaho Falls, ID 83415-3855
No. of

Copies

H. Smith, Jr.

McDonne! Aircraft Company

Dept. 356 MC 1021322

PO Box 516

St. Louis, MO 63166-0516

L. Smith

Niagara Mohawk Power Corp.

Quality Assurance Section

300 Eric Blvd. West

Syracuse, NY 13202

G. Spicring

Teledyne Engrg Services

140 Intracoastal Point Drive

Suite 202

Jupiter, FL 33477-5933

E. W. Throckmorton

Virginia Elec. Power Co.

5000 Old Dominion Blvd.

Glen Allen, VA 23060

C. A. Tomes

Wisconsin Public Serv. Corp.

600 North Adams Street

PO Box 19002

Green Bay, WI 54307-9002

W. G. Wendland

American Nuclear Insurers

29 South Main Street

Town Center, Suite 3005

West Hartford, CT 06107

R. West

Northeast Utilities

Rocky Hill Bldg (B3F3)

PO Box 270

Hartford, CT 06141-0270 
No. of

Copies

\section{FOREIGN}

O. J. V. Chapman

Rolls-Royce \& Assoc. Lmtd

PO Box 31 OR Raynes Way

Derby DE2 8BJ

United Kingdom

A. Kurokawa

Japan Power Engineering

\& Inspection Corporation

Business Court

Shin-Urayasu Bldg.

9-2 Mihama 1-Chome

Urayasu-Shi

Japan

I. Morinaka

Kansai Electric Power Company

Kita-Ku 3-3-22

Osaka

Japan

S. Sakurai

Japan Power Engineering \& Inspection Corporation

Shin-Toranomon Building

5-11 Akasaka 1-Chome

Minato-Ku Tokyo 107

Japan

F. Sasaki

Japan Power Engineering \&

Inspection Corporation

Shin-Toranomon Building

5-11 Akasaka 1-Chome

Minato-Ku Tokyo 107

Japan
No. of

Copies

\section{ONSITE}

50 Pacific Northwest Laboratory

D. M. Boyd

S. H. Bush

A. A. Diaz

S. R. Doctor (10)

J. R. Friley

B. F. Gore

M. S. Greenwood

R. V. Harris

B. K. Hatchell

P. G. Heasler

M. A. Khaleel

R. J. Kurtz

H. K. Phan

F. A. Simonen (10)

B. W. Smith

J. C. Spanner

T. V. Vo (10)

Publishing Coordination

Technical Report Files (5) 

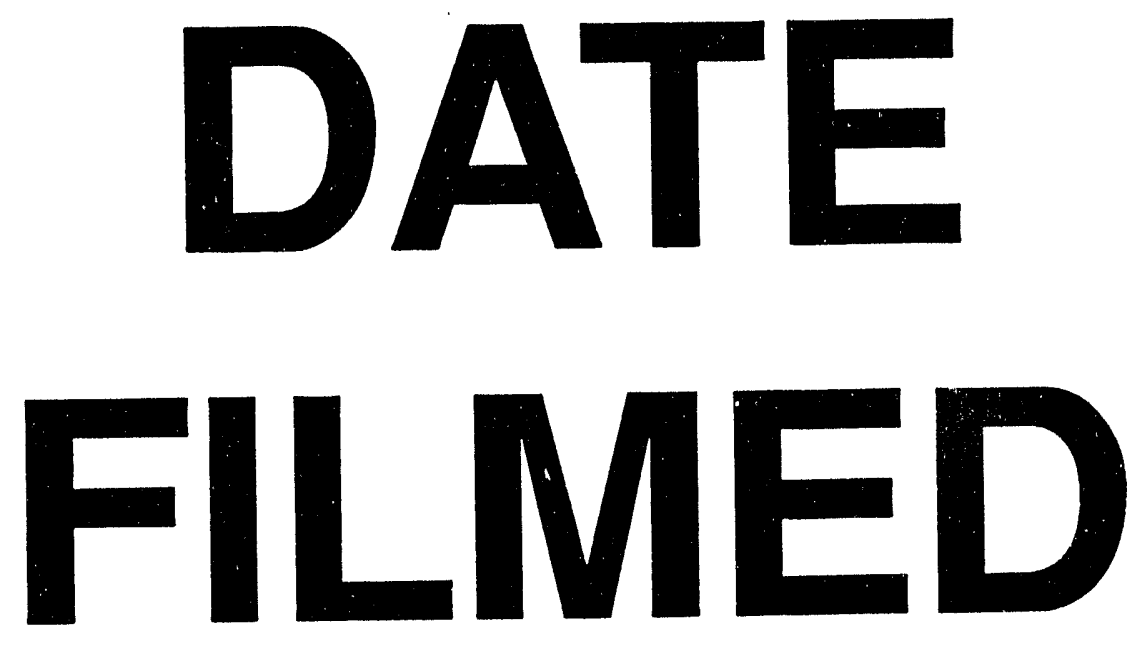

$9 / 29 / 94$
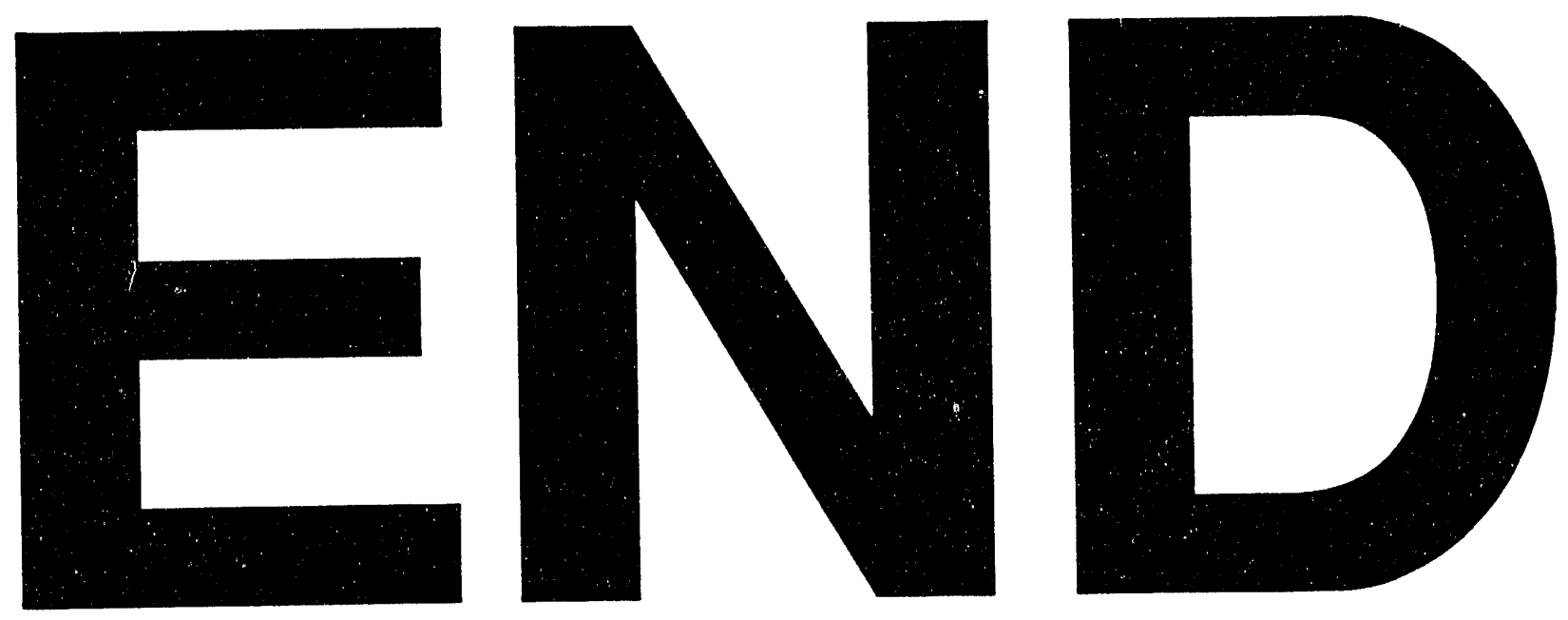


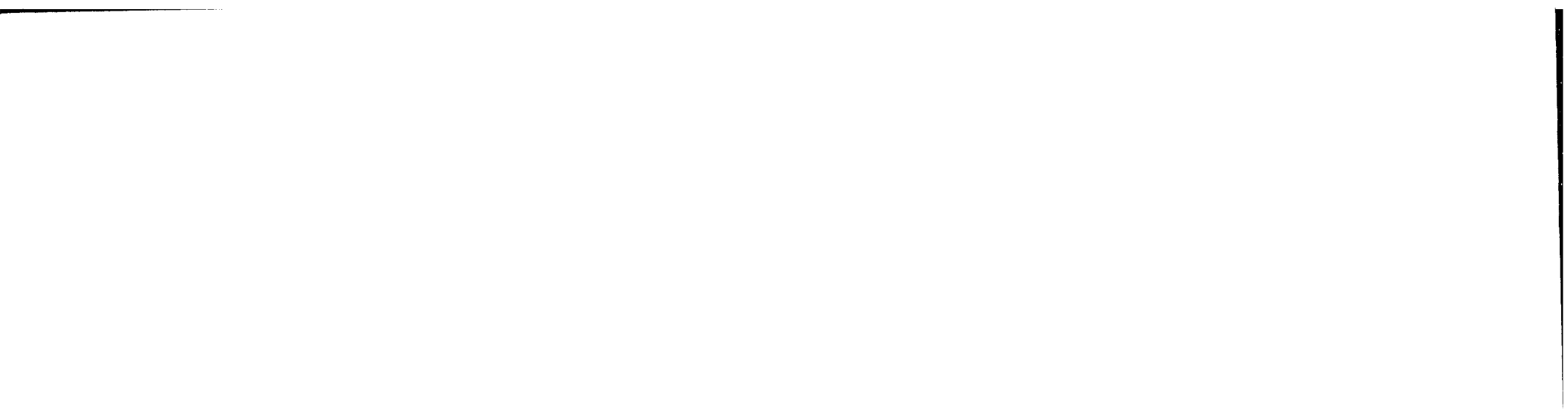

